\title{
Effects of Hydropower Operations on Recreational Use and Nonuse Values at Glen Canyon and Flaming Gorge Dams
}

Decision and Information Sciences Division

Argonne National Laboratory

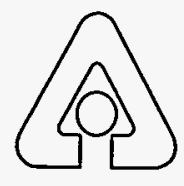

Operated by The University of Chicago, under Contract W-31-109-Eng-38, for the

United States Department of Energy 


\section{Argonne National Laboratory}

Argonne National Laboratory, with facilities in the states of Illinois and Idaho, is owned by the United States Government, and operated by the University of Chicago under the provisions of a contract with the Department of Energy.

This technical memo is a product of Argonne's Decision and Information Sciences (DIS) Division. For information on the division's scientific and engineering activities, contact:

Director, Decision and Information Sciences Division

Argonne National Laboratory

Argonne, Illinois 60439-4815

Telephone (708) 252-5464

Presented in this technical memo are preliminary results of ongoing work or work that is more limited in scope and depth than that described in formal reports issued by the DIS Division.

Publishing support services were provided by Argonne's Information and Publishing Division (for more information, see IPD's home page: http://www.ipd.anl.gov/)

\section{Disclaimer}

This report was prepared as an account of work sponsored by an agency of the United States Government. Neither the United States Government nor any agency thereof, nor any of their employees, makes any warranty, express or implied, or assumes any legal liability or responsibility for the accuracy, completeness, or usefulness of any information, apparatus, product, or process disclosed, or represents that its use would not infringe privately owned rights. Reference herein to any specific commercial product, process, or service by trade name, trademark, manufacturer, or otherwise, does not necessarily constitute or imply its endorsement, recommendation, or favoring by the United States Government or any agency thereof. The views and opinions of authors expressed herein do not necessarily state or reflect those of the United States Government or any agency thereof.

Reproduced directly from the best available copy.

Available to DOE and DOE contractors from the Office of Scientific and Technical Information, P.O. Box 62, Oak Ridge, TN 37831; prices available from (615) $576-8401$.

Available to the public from the National Technical Information Service, U.S. Department of Commerce, 5285 Port Royal Road, Springfield, VA 22161. 


\section{Effects of Hydropower Operations on Recreational Use and Nonuse Values at Glen Canyon and Flaming Gorge Dams}

by J.L. Carison

Policy and Economic Analysis Group, Decision and Information Sciences Division, Argonne National Laboratory, 9700 South Cass Avenue, Argonne, Illinois 60439

March 1995

Work sponsored by United States Department of Energy, Western Area Power Administration

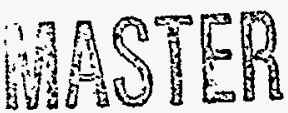


This report is printed on recycled paper. 


\section{FOREWORD}

This report is one of a series of technical memorandums prepared to support an environmental impact statement (EIS) on power marketing prepared by Argonne National Laboratory for the U.S. Department of Energy's Western Area Power Administration (Western). Western markets electricity produced at hydroelectric facilities operated by the Bureau of Reclamation. The facilities are known collectively as the Salt Lake City Area Integrated Projects (SLCA/IP) and include dams equipped for power generation on the Colorado, Green, Gunnison, and Rio Grande rivers and on Plateau Creek in the states of Arizona, Colorado, New Mexico, Utah, and Wyoming.

Western proposes to establish a level of commitment (sales) of long-term firm electrical capacity and energy from the SLCA/IP hydroelectric power plants; the impacts of this proposed action are evaluated in the EIS. Of the SLCA/IP facilities, only the Glen Canyon Dam, Flaming Gorge Dam, and Aspinall Unit (which includes Blue Mesa, Morrow Point, and Crystal dams) are influenced by Western's power scheduling and transmission decisions. For this reason, the impacts of hydropower operations at these three facilities were examined in the EIS.

The technical memorandums present detailed findings of studies conducted by Argonne National Laboratory specifically for the EIS. These studies are summarized in the EIS, and the results were used to assess environmental impacts related to alternative commitment levels. Technical memorandums were prepared on a number of socioeconomic and natural resource topics. Staff members of Argonne National Laboratory's Decision and Information Sciences Division and Environmental Assessment Division prepared these technical memorandums and the EIS as part of a joint effort managed by the Environmental Assessment Division. 


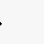




\section{CONTENTS}

FOREWORD $\ldots \ldots \ldots \ldots \ldots \ldots \ldots \ldots \ldots \ldots \ldots \ldots \ldots \ldots \ldots \ldots$

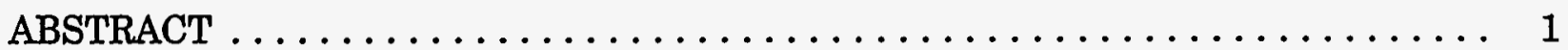

1 INTRODUCTION $\ldots \ldots \ldots \ldots \ldots \ldots \ldots \ldots \ldots \ldots \ldots \ldots \ldots \ldots \ldots \ldots$

1.1 Relationship of this Report to the Glen Canyon EIS . . . . . . . . . . . 2

1.2 Approaches to Measuring Changes in Economic Benefits . . . . . . . . . . 3

1.3 Organization of this Report $\ldots \ldots \ldots \ldots \ldots \ldots \ldots \ldots \ldots \ldots \ldots \ldots \ldots$

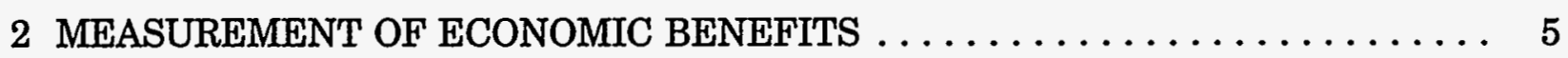

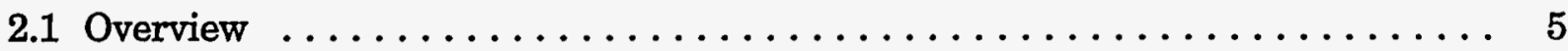

2.2 Definitions ............................. 5

2.2.1 Total Willingness to Pay, Expenditures, and Surplus Value . . . . . . 5

2.2.2 National Versus Regional Economic Benefits . . . . . . . . . . . . . 9

2.3 Total Value: Use Values Versus Nonuse Values . . . . . . . . . . . . . . . . 10

2.3.1 Use Value . . . . . . . . . . . . . . . . . . . . 11

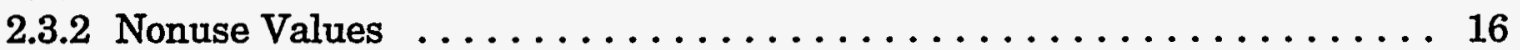

3 EFFECTS OF STREAMFLOWS ON RECREATION AND

NONUSE VALUES . . . . . . . . . . . . . . . . . . . . . . . . . . 19

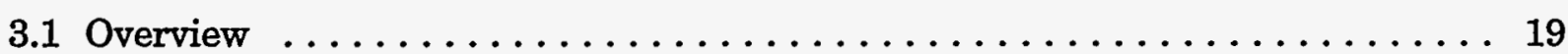

3.2 Relationship Between Streamflows and Recreation . . . . . . . . . . 20

3.2.1 Streamflow and the Quality of Recreation ............... 20

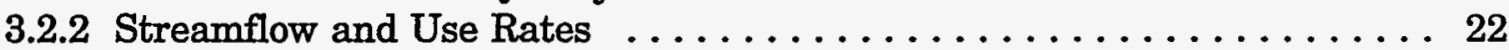

3.2.3 Streamflow and the Economic Value of Recreation ........... 24

3.3 Flow Rates and Nonuse Values . . . . . . . . . . . . . . . 25

4 ANALYTICAL METHODS: REGIONAL ANALYSIS

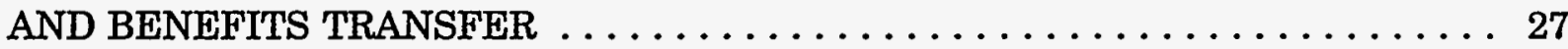

4.1 Impacts to be Estimated $\ldots \ldots \ldots \ldots \ldots \ldots \ldots \ldots \ldots \ldots \ldots \ldots \ldots$

4.2 Regional Economic Impacts: Recreation and Tourism . . . . . . . . . . 27

4.3 National Economic Impacts: Use and Nonuse Values . . . . . . . . . . . . 28

4.3.1 Estimation Techniques . . . . . . . . . . . . . . . . . 29

4.3.2 Use Values for Angling and Boating: Summary

of Relevant Studies . . . . . . . . . . . . . . . . . . . . 32

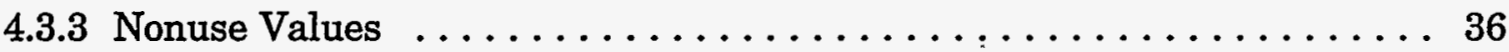

5 ESTIMATED ECONOMIC IMPACTS OF OPERATIONAL SCENARIOS . . . . . . . 37

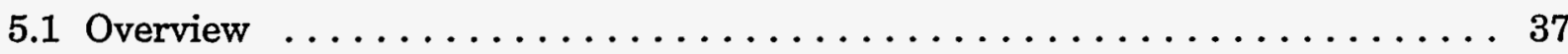

5.2 Site Characteristics and Recreation Use Rates $\ldots \ldots \ldots \ldots \ldots \ldots \ldots$

5.2 .1 Glen Canyon Dam . . . . . . . . . . . . . . . . . . . . 37

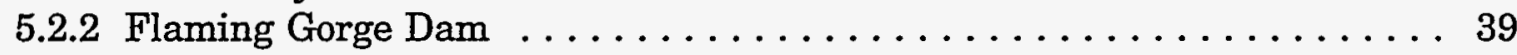




\section{CONTENTS (Cont.)}

5.3 Regional Economic Impacts . . . . . . . . . . . . . . . . . 42

5.3.1 Glen Canyon Dam . . . . . . . . . . . . . . . . . 42

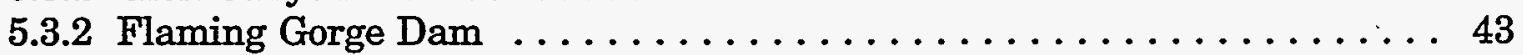

5.4 Recreation Use Values $\ldots \ldots \ldots \ldots \ldots \ldots \ldots \ldots \ldots \ldots \ldots \ldots \ldots \ldots \ldots \ldots$

5.4 .1 Glen Canyon Dam . . . . . . . . . . . . . . . . . 45

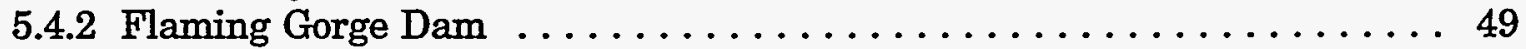

5.5 Nonuse Values . . . . . . . . . . . . . . . . . . . . 55

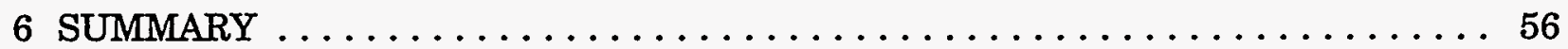

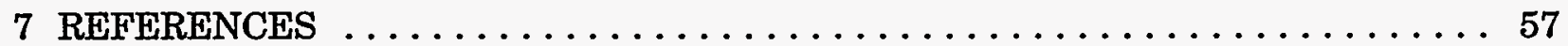

APPENDIX: Procedures Used to Estimate Expenditures and Use Values . . . . . . . 61

FIGURES

1 Relationships among Streamflows, Recreation, and Regional and National Economic Impacts $\ldots \ldots \ldots \ldots \ldots \ldots \ldots \ldots \ldots \ldots \ldots$

2 Total Willingness to Pay Versus Consumer Surplus . . . . . . . . . . . 6

3 Effects of a Shift in Demand or Supply on Total Consumer Surplus . . . . . . . . 8

4 Relationship between Streamflows and Boater Satisfaction on the Dolores River ............................... 21

\section{TABLES}

1 Green River Spillway to Colorado Border: Recreation Use Data for Angling and Boating ......................... 41

2 Green River in Dinosaur National Monument: Recreation Use Data for Boating $\ldots \ldots \ldots \ldots \ldots \ldots \ldots \ldots \ldots \ldots \ldots \ldots \ldots \ldots \ldots \ldots \ldots \ldots$

3 Green River: Recreation-Related Expenditures per Person/Day . . . . . . . . . . 44

4 Summary of Recreation Use Values Associated with Each Operational Scenario at Glen Canyon Dam . . . . . . . . . . . . . . . . . . 46

5 Summary of Surplus Values for Angling and Boating below Glen Canyon Dam 


\section{TABLES (Cont.)}

6 Summary of Recreation Use Values Associated with Each Operational

Scenario at Flaming Gorge Dam . . . . . . . . . . . . . . . 53

A.1 Green River, Utah: Angling-Related Expenditures . . . . . . . . . . . 62

A.2 Green River, Utah: Boating-Related Expenditures . . . . . . . . . . 63

A.3 Monthly and Total Annual Use Values for Angling on the Green River by Operational Scenario and Hydrological Condition . . . . . . . . . . . 64

A.4 Monthly and Total Annual Use Values for White-Water Boating in Dinosaur National Monument by Operational Scenario and Hydrological Condition $\ldots \ldots \ldots \ldots \ldots \ldots \ldots \ldots \ldots \ldots \ldots \ldots \ldots$ 


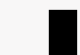




\title{
EFFECTS OF HYDROPOWER OPERATIONS ON \\ RECREATIONAL USE AND NONUSE VALUES \\ AT GLEN CANYON AND FLAMING GORGE DAMS
}

by

J.L. Carlson

\begin{abstract}
Increases in streamflows are generally positively related to the use values of angling and white-water boating, and constant flows tend to increase the use values more than fluctuating flows. In most instances, however, increases in streamflows beyond some threshold level cause the use values to decrease. Expenditures related to angling and white-water boating account for about $\$ 24$ million of activity in the local economy around Glen Canyon Dam and \$24.8 million in the local economy around Flaming Gorge Dam. The range of operational scenarios being considered in the Western Area Power Administration's Electric Power Marketing Environmental Impact Statement, when use rates are held constant, could change the combined use value of angling and white-water boating below Glen Canyon Dam, increasing it by as much as 50\%, depending on prevailing hydrological conditions. Changes in the combined use value below Flaming Gorge Dam could range from a decrease of $9 \%$ to an increase of $26 \%$. Nonuse values, such as existence and bequest values, could also make a significant contribution to the total value of each site included in this study; however, methodological and data limitations prevented estimating how each operational scenario could change nonuse values.
\end{abstract}

\section{INTRODUCTION}

The results of recent research indicate that the quality and quantity of certain recreational activities, such as angling and white-water boating (which includes rafting, kayaking, and canoeing, among others), are related to streamflows. Therefore, a change in dam operations that results in a change in streamflows could cause the quantity or quality of downstream recreational activities to change. (The extent to which an operational scenario would affect recreation depends on the magnitude of the resulting change in streamflows and the strength of the relationship between streamflows and recreational activities.) Consequently, as part of its Electric Power Marketing Environmental Impact Statement (EIS), Western Area Power Administration (Western) examined the effects that different dam operations, referred to as operational scenarios, could have on recreation below certain dams. This technical memorandum describes the method used to estimate the effects of different 
operational scenarios at Glen Canyon Dam and Flaming Gorge Dam on the value of downstream recreation. In particular, the economic impacts on angling and white-water boating are addressed. In addition to considering recreation use values, this report also addresses values that individuals attach to each site but that are independent of any actual use of the site's resources (i.e., nonuse values, a concept defined in Section 2.3.2).

Consideration of the potential effects of alternative operational scenarios on the benefits from recreational activity at the affected sites is a relevant topic for the Power Marketing EIS. A monetary valuation of the impacts on recreation provides additional insights regarding the potential effects of a change in Western's power marketing programs. In addition to facilitating a comparison of the potential tradeoffs among different recreational activities, the valuation provides a common basis for comparing such diverse effects as changes in recreation at affected sites and changes in the rates charged to utility customers. For example, a reduction in streamflows may adversely affect the quality of white-water boating while simultaneously improving the quality of angling. At the same time, a change in streamflows resulting from a change in dam operations could lead to a change in the rates charged to end-use customers. Monetary valuation of these impacts enables decision makers to determine whether recreationists and ratepayers are in a better or worse position as a result of the change.

\subsection{RELATIONSHIP OF THIS REPORT TO THE GLEN CANYON EIS}

As part of its Glen Canyon Environmental Studies (GCES), the Bureau of Reclamation (Reclamation) is completing an EIS on the effects of alternative dam operations on the environmental and ecological resources of Glen Canyon National Recreation Area and Grand Canyon National Park. Affected resources consist of (1) physical resources including downstream river flows, water quality, sedimentation and river bed characteristics, beaches, and backwaters; (2) biological resources including vegetation, wildlife, wildlife habitat, and fisheries; (3) recreational resources including fishing, day rafting, white-water boating, and camping; (4) hydropower resources; (5) sociocultural resources; (6) economic resources; and (7) aesthetic resources.

Phase I of the GCES included an assessment of the effects of operations on the value of the benefits of recreational activities along the Colorado River below Glen Canyon Dam (Bishop et al. 1987). More recently, the decision was made to investigate the effects of changes in dam operations on the "total value" associated with the hydro resource. As it is used here, the term total value refers to the value associated with the various uses of the hydro resource as well as the nonuse value ascribed to the resource, which is independent of actual uses.

The results reported in Bishop et al. (1987) and BOR (1993) formed the basis for the estimates of the impacts of different operational scenarios on the benefits of recreation below Glen Canyon Dam reported here. In addition, these results were used as the basis for estimating the recreation-related impacts of operational scenarios at Flaming Gorge Dam. 


\subsection{APPROACHES TO MEASURING CHANGES IN ECONOMIC BENEFITS}

The relationships among streamflows and the regional and national economic benefits attributable to recreation are illustrated in Figure 1. A change in streamflows has the potential to alter both the quantity and the quality of recreational activities at each affected site. At the regional level, economic impacts are measured on the basis of changes in recreation-related expenditures in the local economy; at the national level, economic impacts are measured by changes in the welfare of the producers and consumers of recreation-related goods and services.

At the regional level, economic impact analysis focuses on the effects of a change in an exogenous variable (e.g., the amount spent on recreation-related items) on other variables in the regional economy, including income and employment. Other variables of interest include relative price levels and the value of total output in the region. In this type of analysis, regional economic impacts are estimated on the basis of predicted changes in expenditures on recreational activities and the application of relevant multipliers. This method is explained more fully in Section 2.2.2.2.

At the national level, analysis of economic impacts focuses on the potential effects of a proposed change, such as a change in dam operations, on the net benefits (i.e., welfare) of consumers and producers. In this analysis, regional employment and income effects are assumed to "wash out" at the national level, and the focus shifts to the level of welfare in the economy. (The relevant aspects of welfare theory are described in Section 2.2.) National

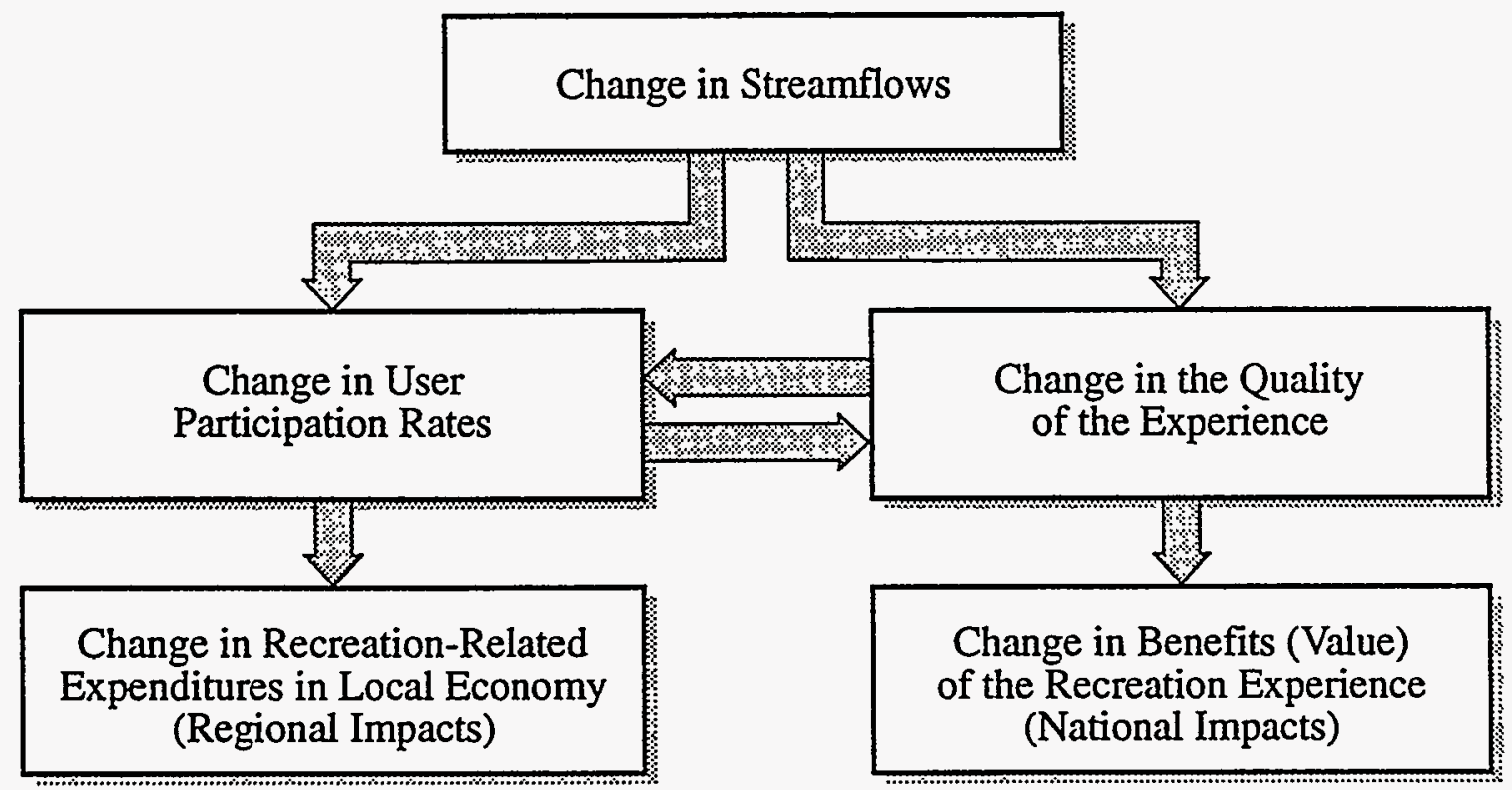

FIGURE 1 Relationships among Streamflows, Recreation, and Regional and National Economic Impacts 
economic impacts can be estimated on the basis of primary data (i.e., an original study of the policy question) or through the use of "benefits transfer." As its name suggests, benefits transfer uses the results of previous studies to estimate the economic welfare effects (or at least some portion of those effects) attributable to the proposed policy.

\subsection{ORGANIZATION OF THIS REPORT}

The remainder of this report is structured as follows. Section 2 describes the basic approach to measuring the economic benefits of recreation at the regional and national levels. Section 3 addresses the relationship between streamflows and recreation, focusing on how variations in streamflows affect the quantity and quality of different activities. Section 4 addresses specific issues associated with the estimation of regional economic impacts and the use of benefits transfer to estimate welfare effects. The relevant literature on benefits estimates for angling and white-water boating is also reviewed, summarized, and evaluated. Section 5 summarizes relevant characteristics (e.g., the range of recreational activities or use rates) at each of the affected sites. It also presents estimates of the regional and national economic impacts of each of the operational scenarios considered in the Electric Power Marketing EIS. 


\section{MEASUREMENT OF ECONOMIC BENEFITS}

\subsection{OVERVIEW}

Producers and consumers of a variety of goods and services, including agricultural products, hydro-generated electrical power, and recreational activities (e.g., white-water boating, angling, hiking, camping) derive benefits from the rivers in the Salt Lake City Area Integrated Projects (SLCA/IP) market area. However, certain demands for water can cause conflicts, as occurs when water is withdrawn for agricultural irrigation at the expense of maintaining an instream flow for recreational uses. Similar conflicts can arise when streamflows are manipulated to accommodate the production of hydro-generated electrical power. Streamflow patterns are both a residual of hydropower generation and an input to the production of recreational services. Depending on the pattern of power generation, the resulting streamflows can enhance or diminish the quality of downstream recreation.

As was noted previously, a change in streamflows may alter the quantity and quality of recreational activities at a site. (The relationship between changes in streamflows and the quality of recreational experiences is discussed more fully in Section 3.) Such changes can also have economic effects at both the national and regional levels. For example, instream flows are a major determinant of the quality of boating and angling and therefore the benefits received by recreationists. At the same time, the amount of revenue received by many recreation-related businesses, such as commercial outfitters that offer white-water boating trips and angling guide service, is heavily dependent on instream flows. As recreation-related expenditures vary, a change in streamflows can also influence the level of economic activity in the surrounding region. In addition, there is the potential for effects on nonuse benefits (i.e., benefits accruing to individuals who do not directly use the hydro resource but nonetheless attach a positive value to its existence). The methods used to measure these economic effects are described in the next few sections.

\subsection{DEFINITIONS}

\subsubsection{Total Willingness to Pay, Expenditures, and Surplus Value}

According to the theory of welfare economics, the gross benefits (measured in monetary terms) derived from a good (or service) are measured by the aggregate willingness to pay (WTP) for the good. WTP can be divided into two components: (1) actual expenditures for the good and (2) any additional amount individuals would pay for the continued right to consume the quantity in question. This latter amount, which is equal to the difference between total WTP and actual expenditures, is called surplus value or "consumer surplus." 1

1 Consumer surplus is not the same as net benefits, except under certain conditions. Net benefits are defined as gross benefits minus total variable costs; consumer surplus is that portion of net

(continued...) 
These concepts are illustrated in Figure 2, which depicts the demand curve for recreation at a site (e.g., a stretch of river). The demand curve indicates the maximum amount that recreationists are willing (and able) to pay for each user day at the site. ${ }^{2}$ As such, maximum WTP is $P_{1}$ for $Q_{1}$ user days, $P_{2}$ for $Q_{2}$ user days, and so forth. According to Figure 2, the equilibrium price is $\mathrm{P}^{*}$. A total of $\mathrm{Q}^{*}$ user days at the site is "purchased" at a per-unit price of $\mathrm{P}^{*}$, where $\mathrm{P}^{*}$ represents the average daily entrance fee to the site (which could also be zero). Assuming there is an entry fee, total expenditures are $P^{*} \times Q^{*}$, shown by the rectangle $O P^{*} \mathrm{AQ}^{*}$. However, according to the demand curve, recreationists would actually be willing to pay an amount equal to the area. $O B A Q^{*}$ for $Q^{*}$ user days. The difference between total WTP and actual expenditures - the triangle $\mathrm{P}^{*} \mathrm{BA}$ in Figure 2 is the amount of consumer surplus derived from consuming $Q^{*}$ user days at the site. $\mathrm{P}^{*} \mathrm{BA}$ represents the amount by which consumers are in a better position as a result of consuming $Q^{*}$ user days.

A shift in either the demand curve or the supply curve (represented in Figure 2 by the price line) results in a change in consumer surplus. A shift in the demand (supply) curve is caused by a change in any determinant of demand (supply) other than the price of the good. If changes in supply are ignored for the moment, there are a number of factors that could cause the demand for access to a specific recreation site to change (i.e., the demand curve to shift). Such factors include a change in the availability or price of substitute sites,

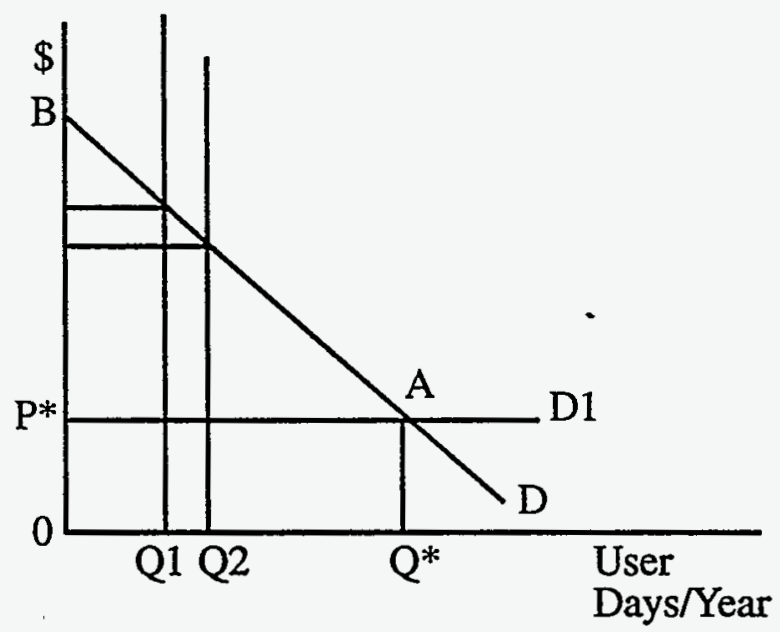

FIGURE 2 Total Willingness to Pay Versus Consumer Surplus

${ }^{1}$ (...continued)

benefits that accrues to consumers. The remaining portion of net benefits accrues to producers in the form of producer surplus (i.e., the amount by which total expenditures exceed total variable costs).

2 As an alternative to user days, activity could be measured as the number of site visits per time period. User days were selected since this unit of measurement is used to report empirical estimates of benefits later on. 
in the average level of income of site visitors, and in the quality of recreational opportunities at the site. With regard to the latter factor, streamflows are an important determinant of the quality of recreational activities such as white-water boating and angling (Section 3).

In the preceding example and the discussion that follows, the quantity of recreational activity demanded and supplied is measured as the number of user days at a site per year. The site itself can be characterized as a fixed number of miles of stream that are available to use (accessible) for a variety of activities such as angling or boating. Except in extreme circumstances, a change in streamflows does not directly alter the number of miles (quantity) of stream to which users have access. (The obvious exceptions would be those cases in which streamflows are reduced below or increased above some predetermined pair of thresholds, below or beyond which no type of recreation is possible.) Instead, a change in streamflows alters the quality of the resource as an input to the production of specific activities. Thus, a change in streamflows affects the demand side of the market.

Alternatively, one could conceptualize the problem by dividing streamflows into a series of ranges. One could then think of supply in terms of the number of days of streamflow in a given range that are supplied per broader time period (e.g., per year). Thus, a series of supply and demand curves would correspond to a particular site. In this approach, demand would depend on the time of year during which such supplies were made available as well as the other usual nonprice determinants. However, this type of approach would probably unduly complicate the analysis. Moreover, it is not clear whether an analysis of the welfare effects of a change in streamflows would yield results different from those obtained in the case where streamflows enter solely as a determinant of demand. Most importantly, the approach adopted here is consistent with previous studies. This internal consistency is necessary for the benefits transfer described in Section 5 .

In economic terms, instream flow is an input for creating certain recreational opportunities. Other inputs could include rods, reels, and tackle for angling or a raft or other type of water craft for white-water boating. Variations in streamflows (as well as other inputs) can affect the quality of the resulting recreational experience. Thus, a change in streamflows may cause a change in recreationists' demand or WTP for use of the stream (i.e., the demand curve will shift). If the change in streamflows is perceived as increasing the quality of the recreational experience, WTP (demand) will increase (i.e., the demand curve will shift right). A change in streamflows that is perceived as reducing the quality of the recreational experience will have the opposite effect on WTP; demand will decrease.

A change in streamflows that alters the quality of the recreational experience will alter the value of the recreational experience. In addition, a change in streamflows may cause the total quantity of user days at a site per time period to change. For example, consider the number of user days per month at a site. Streamflows at a given location are influenced by a number of factors, including precipitation, run-off from melted snow, and release patterns from upstream reservoirs. In general, recreational activities such as whitewater boating tend to take place in the spring and summer, in large part because streamflows naturally decrease in late summer and through the winter. A change in release patterns that 
would result in higher flows during the late summer (or early spring) could effectively extend the white-water boating season. The increased demand for white-water boating would be reflected by an increase in user days during those months and consequently in user days per year. Conversely, a change in release patterns that would shorten the boating season would result in a decrease in user days. A change in dam operations could also result in an increase or decrease in the number of user days during peak months.

As shown, changes in the quality of the recreational experience that affect the demand for a site can affect aggregate net benefits both directly and indirectly. A change in quality directly affects WTP for access to the site. Thus, even if the total number of user days were to remain constant, ${ }^{3}$ total consumer surplus would nonetheless change. Morover, if the change in quality and the corresponding shift in the demand curve resulted in a change in the total number of user days, consumer surplus would be further altered.

The change in benefits resulting from a change in the level of quality associated with a recreational resource is measured as the area between the two demand curves (i.e., the shaded area in Figure 3a). ${ }^{4}$ Similarly, an increase in supply (a downward shift of the supply curve) would also cause consumer surplus to increase. In this case, the change in benefits is measured by the area between the two supply curves and to the left of the demand curve (i.e., the shaded area in Figure $3 b$ ).

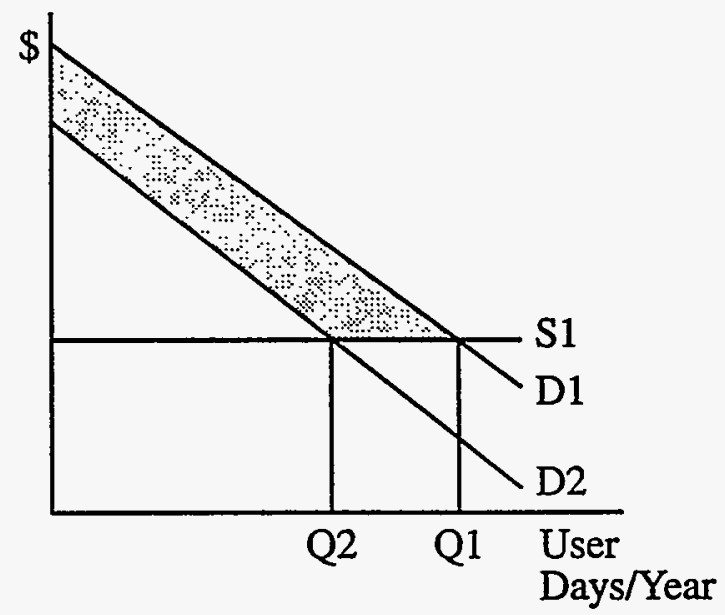

(a)

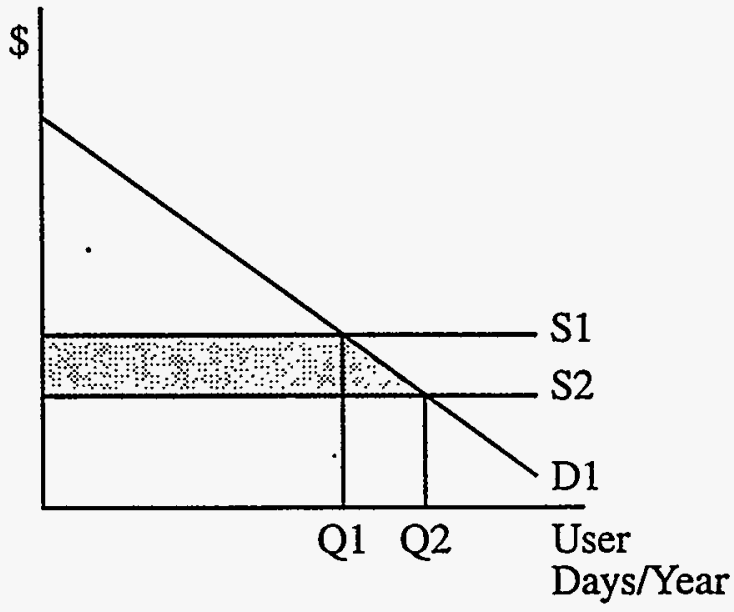

(b)

FIGURE 3 Effects of a Shift in Demand or Supply on Total Consumer Surplus

3 This possibility could occur if there was excess demand for a site (e.g., because of permit requirements) and if an increase or a decrease in demand (e.g., because of other factors) was not sufficient to eliminate the shortage.

4 The technically correct measure of the change in consumer surplus would be the area between the income-compensated demand curves (Freeman 1979). However, it has been shown by Willig (1976) that under reasonable assumptions, the ordinary Marshallian demand curve provides a reasonable estimate of changes in consumer surplus. 
As the preceding discussion has shown, total WTP can be divided into two components: total expenditures and consumer surplus. Analyses use each of these measures to estimate the economic benefits from a good or service. However, the choice of which component to use depends on the scope of the analysis.

\subsubsection{National Versus Regional Economic Benefits}

When a change in benefits is being evaluated at the level of the national economy, changes in surplus values are the appropriate measure of this change. However, when this change is being evaluated at the regional level, surplus values are ignored. Instead, the focus of the analysis is on the change in expenditures and employment effects in the local (regional) economy.

\subsubsection{Measurement of Benefits at the National Level: Surplus Value}

Viewed from the national level, the expenditures incurred to consume the services that can result from using a resource such as a mountain stream are irrelevant to the estimation of total benefits. This approach reflects the assumption that money that is not spent at the site in question will simply be spent elsewhere in the economy. As such, any change in income and employment in one region of the economy will be offset by a corresponding (but opposite) change in some other region. For example, assume that a change in operations at Flaming Gorge Dam would reduce the angling quality and hence the number of anglers on the Green River below the dam. Such a change would likely result in a decrease in angling-related expenditures in the regional economy. However, if one were to assume that the anglers who stopped using the Green River would simply use another site in another region, it would reasonable to assume that there would be a corresponding shift in expenditures to the region in which the new site is located. Hence, income and employment effects in the two regions would tend to offset each other. It is also possible that the substitute site and the Green River could lie within the same region. Once again, the effect would be no change in total regional expenditures.

When the potential impacts of a policy are viewed from the national level, the change in surplus values attributable to the policy in question is the appropriate measure of the economic benefits of the policy. The change in surplus values (e.g., consumer surplus) measures the amount by which individuals are in a better (or worse) position as a result of the policy. In the Flaming Gorge example, even though expenditures would remain unchanged, the effect of the shift to the substitute site on surplus values would be less clear. Although the same total number of angling trips might take place (albeit to different locations), total WTP might diminish. This result would occur if the quality of the substitute site were poorer than the quality of the Green River before the change in question. Consumer surplus would decrease, indicating a net loss of benefits at the national level. 


\subsubsection{Measurement of Benefits at the Regional Level: Expenditures}

When the benefits of a policy option are assessed at the regional level, expenditures become the focus of the analysis. In particular, the assessment addresses the effects of a change in expenditures on the levels of income and employment in the regional economy. One of the primary underlying assumptions of regional economic analysis is that changes in expenditures result in changes in income and employment. The link between expenditures on the one hand, and income and employment on the other, is known as the multiplier process.

According to the theory of the multiplier, a change in spending in the local economy will result in a change in income that is some multiple of the initial spending change. For example, if a resident of Salt Lake City, Utah, were to fish on the Green River below Flaming Gorge Dam, expenditures on such items as food, lodging, and transportation in a nearby town (e.g., Vernal, Utah) would constitute additional income to the providers of those goods and services (i.e., the owners of the affected establishments). To the extent that this additional income would be re-spent in Vernal on other goods and services, additional income would be generated. The multiplier process stops when the additional income is spent outside the region or is saved rather than spent. The magnitude of economic impacts attributable to a change in expenditures can be estimated with the use of regional multipliers.

The generally positive relationship between the levels of output and employment implies that a change in expenditures has effects on employment as well. For example, as the demand for certain services increases, so does the demand for resources (including labor) required to produce those services. Thus, increased expenditures in the regional economy are likely to have positive employment impacts. The question of whether, in fact, there will be employment effects depends on the magnitude of the change in expenditures and the degree to which employable resources are unemployed.

\subsection{TOTAL VALUE: USE VALUES VERSUS NONUSE VALUES}

As it is used in this analysis, the term "total value" is used to describe the total amount individuals are willing to pay for a resource of a given quality. As a result of its focus on WTP, total value is associated with national benefits as opposed to regional benefits. Resources such as the Green River or the Colorado River have the potential to yield economic value to many diverse groups of people. These groups include producers and consumers of hydro-generated electricity, irrigation-dependent agricultural products, and recreational activities. As is discussed below, it is also possible for individuals who have no direct or indirect contact with the resource to derive economic value from its existence.

Obviously, there is a potential for conflict among the competing uses (and nonuses) of a resource. For example, irrigation requires the withdrawal of water and reduces downstream flows. Presumably, agricultural interests are in a better position because of such actions. However, recreationists (and possibly producers and consumers of hydro-generated electricity) might be in a worse position. Individuals who value the resource in its natural 
condition may also be adversely affected. Depending on how the resource is ultimately allocated, other tradeoffs (e.g., tradeoffs between hydro-generation of electricity and recreation) could occur. Economic efficiency requires that each of these potential tradeoffs be considered in deciding how to allocate the resource to competing uses in a manner that would maximize its economic value.

The total value of a natural resource can be divided into two principal components: use value and nonuse value. In addition, the concept of "option value" has been developed to further distinguish the separate components that make up the total value of a resource. Alternatively, the total value of a resource can be calculated as the sum of the individual use values and nonuse values - and possibly option values - resulting from a specific allocation of the resource. Thus, focusing on the estimation of a single component of use values, such as recreation values, provides empirical information on only a portion of total value.

This analysis addresses only a portion of the total values in question - the recreation-related use values and any nonuse values associated with each of the sites. Additional sources of use value (e.g., the value of electricity and irrigation derived from streamflows at each site) are not considered here. As such, the empirical estimates presented in Section 5 do not represent total values.

\subsubsection{Use Value}

The term "use value" refers to the value of the direct (and sometimes indirect) uses to which a resource can be put. For example, the potential uses of streamflow in the Colorado River include irrigation, hydropower generation, and recreation. The value of each of these uses is conditional on such characteristics as the total amount and variation of streamflows and the availability of close substitutes (e.g., fossil-fuel-generated power and recreation on another river). As discussed in Section 2.2.1, the use values of a resource are measured by consumers' total WTP (i.e., the sum of expenditures and surplus values). To illustrate a case of recreational use value, the surplus value (net use value) of white-water boating on the Colorado River below Glen Canyon Dam has been estimated to be between $\$ 28$ and $\$ 1,179$ (1994 dollars) per person per trip, with much of the range being accounted for by variations in streamflows (Bishop et al. 1987). The range of values reflects the effects of various factors, including the level and variability of the flow rate of the river, and whether the trip was organized by a private or commercial provider. This benefit is measured as the average amount by which total WTP exceeds average actual expenditures.

The focus of this analysis is on the present value of benefits from nonuse values and recreational use values that are expected to accrue over the years 1993-2008. One of the important assumptions that must be made when estimating future use values concerns the degree of certainty associated with the supply of and demand for a resource. When supply and demand are certain, consumer surplus is the correct measure of benefits. To estimate the present value of future benefits, average consumer surplus is multiplied by the expected number of users in each year, and the appropriate discount rate is applied. However, as the discussion below illustrates, uncertainties on either the demand side or supply side can have 
important implications for this theoretically correct approach to the estimation of surplus values.

The concept of "option value," which was first introduced by Weisbrod (1964), has evolved considerably over time. As originally proposed, option value referred to the value that an individual attaches to the option to use a resource at some future point in time, assuming uncertainty with respect to the future supply of the resource. Weisbrod developed the concept of option value by way of an example in which a decision had to be made whether to preserve a national park or reallocate those resources to other uses such as timber harvesting. According to Weisbrod (1964, p. 472):

. . the reader need recognize the existence of people who anticipate purchasing the commodity (visiting the park) at some time in the future, but who, in fact, never will purchase (visit) it. Nevertheless, if these consumers act as "economic men" they will be willing to pay something for the option to consume the commodity in the future. This "option value" should influence the decision of whether or not to close the park and turn it to an alternative use.

Subsequent theoretical work has focused on a number of related questions, including (1) how option value should be measured; (2) whether, in fact, option value is always positive; and (3) whether the question of option value is even relevant to the decision-making process. One of the major results of these research efforts is that option value is not, of itself, a separate component of the total value of a resource. Rather, as demonstrated by Schmalensee (1972), option value is equal to the difference between two alternative measures of the use value of a resource in the presence of uncertainty. To be specific, option value is equal to the difference between option price and expected consumer surplus. Option price is defined as the state-independent, ex ante valuation of the option to use the resource at some future date. ${ }^{5}$ Expected consumer surplus is an ex post measure of the use value of the resource. As Schmalensee (1972), Graham (1981), Bishop (1982), and Freeman (1984) have shown, option value can be positive, negative, or zero, depending on the source of the uncertainty and the degree of risk aversion of the affected consumers. However, in more recent efforts, Cory and Saliba (1987) and Randall (1989) have concluded that option value and option price are irrelevant. Because there is no clear consensus on this point, this analysis considers first the implications of uncertainty for option value. It then turns to the more recent arguments that favor abandoning the option value concept entirely.

The uncertainty that gives rise to option value can occur on the demand side, the supply side, or both sides. Demand-side uncertainty refers to the situation in which the consumer is unsure of future demands because income, prices of goods, preferences, or some other determinant of demand might change. For example, an individual's preference for a particular recreational site may depend on prevailing weather conditions and other site-

5 As Bishop (1982) has pointed out, it is not clear whether Weisbrod was thinking in terms of option value or option price. 
specific characteristics (e.g., streamflows). A change in such conditions would cause the individual's preference and therefore demand for the site to change. This type of uncertainty is the type most likely to characterize the type of problem considered here.

Supply uncertainty describes a situation in which uncertainty exists with respect to the quantity of the resource that will be available at some future date. For example, discussions about the possibility of damming a canyon to create a reservoir would result in supply uncertainty. This uncertainty can be expected to influence individuals' expressions of WTP for access to the site at some future date. Once a decision about whether to build the dam is made and the policy is enacted, however, this source of supply uncertainty no longer exists. Instead, the valuation problem can proceed on the assumption that supply is certain.

Schmalensee (1972) has shown that depending on the circumstances of the particular problem, option value can be positive, negative, or zero (i.e., option price can be greater than, less than, or equal to expected consumer surplus). Because of these findings, Schmalensee argued that expected consumer surplus should be used as the appropriate measure of benefits under conditions of uncertainty. Schmalensee (1972, p. 823) states that:

.. .when tastes are the main source of uncertainty, the expected value of consumers' surpluses ought to be employed as the best available approximation to the sum of their option prices. ... Benefits will be sometimes underestimated and sometimes overestimated with this procedure, but there would appear to be no practical way to obtain superior estimates.

Freeman (1984) has lent some additional support to this suggestion, noting that "in many instances the most readily attainable information is expected surplus" (p. 1). However, other authors (Graham 1981) have argued that option price may be the preferred measure of benefits in many situations. Therefore, the sign and potential magnitude of option value merits further consideration.

Subsequent research has considered the conditions under which the sign and relative size of option value can be predicted. Freeman (1984) has focused on situations involving demand uncertainty attributable to uncertainty over future preferences and income. According to Freeman's results, in a case in which demand uncertainty results from statedependent preferences, unless individuals are extremely averse to risk or expected consumer surplus is large relative to total income, option value will be positive but low, usually less than 1\% of expected consumer surplus. In a case in which demand uncertainty results from uncertainty about future incomes, option price will be negative in most cases and could be large relative to expected consumer surplus.

Smith (1984) has offered a more general expression of the bound that can be placed on option value. Smith considers the ratio of option value to expected consumer surplus. According to the results of his analysis, this bound depends on the uniqueness of the resource and the probability of demand for access to the site at some future date. As the uniqueness 
of the site increases, option value as a percentage of expected consumer surplus also increases. As the probability of demand for access to the site declines, the same effect occurs.

Bishop (1982) addresses the question of supply uncertainty. According to his results, in a case in which only supply uncertainty exists (i.e., demand is certain), option price will exceed expected consumer surplus, and option value will be positive. Bishop (1982, p. 14) argues that:

This conclusion would appear to be applicable in many natural resource situations. ... Nor is there a strong a priori case for arguing that such option values will be relatively small. ... On the other hand, since option value depends on the diminishing marginal utility of income, one would expect it to be substantially less than the expected value of consumer surplus.

The preceding discussion suggests that option values for the resources considered here may be positive and nontrivial. This assertion is based on the observation that each of the affected sites is considered to be more or less unique in one or more dimensions (see Section 5.2). However, it is not clear whether, and to what extent, uncertainty plays a role in this situation.

In the context of the changes being addressed in the Electric Power Marketing EIS, questions regarding the magnitude of option values may not be relevant. In particular, care must be taken when considering how supply and demand are measured. In one scenario, supply is measured, at least in part, on the basis of streamflows. Currently, Western has some latitude in timing the water releases from each dam it operates on a daily and weekly basis. Recreationists therefore cannot be certain what type of streamflows they will experience on a given day, independent of any naturally occurring impacts to hydrology. However, release patterns are somewhat regular. In addition, both the Green River below Flaming Gorge Dam and the Colorado River below Glen Canyon Dam have exhibited fairly steady flows in recent years during the high-use months for recreation. Thus, it might be argued that in this scenario, supply uncertainty is minimal.

If, in another scenario, supply is measured on the basis of access to the site, supply uncertainty essentially vanishes. (The exceptions, once again, are those situations in which streamflows either fall below or increase beyond a pair of predetermined thresholds below and above which recreational activity is not possible.) As long as access to the site is unchanged, the effects of changes in streamflows, either potential or realized, appear on the demand side of the market. The implication is that any relevant option values will enter from the demand side.

According to the earlier discussion of the relationship between option value and demand-side uncertainty, option value can be signed under certain conditions. Particularly if demand uncertainty results from uncertainty of preferences, option value most likely will be positive, although small. In contrast, if demand uncertainty is a result of income uncertainty, option value may be negative. An obvious question that arises is whether all 
affected consumers will be subject to either of these uncertainties. It is possible for offsetting sources of uncertainty to be present. To the extent that this is the case, Schmalensee's (1972) conclusion becomes more persuasive.

Another factor to be considered with respect to option value is the role of irreversibility. Much of the literature on option value has developed, in part, on the basis of the notion that potential changes to the affected resource are irreversible; once a change is implemented, it is not possible to restore the resource to its former condition in a reasonable length of time. An example of an irreversible action is the construction of Glen Canyon Dam and the filling of Glen Canyon to form Lake Powell. While the policy options being considered in the Electric Power Marketing EIS could result in a measurable change in streamflow patterns, it does not appear that such actions should be termed irreversible. (A possible exception would be a change in flows that results in the destruction of a fishery. Even in this case, however, restoration of the former flow regime combined with a stocking program might rejuvenate the fishery in a relatively short period of time.) This prospect for reversibility would further reduce the potential for supply-side uncertainty. 6

The final factor to consider is the results of recent work by Cory and Saliba (1987) and Randall (1989). In Cory and Saliba, the argument is made that neither of the two measures discussed thus far - option price and expected consumer surplus - is the correct measure of future benefits. If this assertion is correct, it effectively eliminates option value as a relevant consideration, because it is equal to the difference between option price and expected consumer surplus. Instead, Cory and Saliba argue for the use of what is known as the expected value of the "fair bet point." This value is derived from Graham's (1981) WTP locus and represents the maximum expected value of WTP for contingent claims to alternative future states of the world. According to Cory's and Saliba's analysis, this value, which will always exceed option price and expected consumer surplus, is the correct measure of maximum WTP.

The results of Cory and Saliba might be viewed as simply another complication in the debate over option value. In fact, some doubt is shed on the validity of their results insofar as option price and expected consumer surplus are comparable to one another. This point is raised by Smith (1987b), who argues that because these measures represent ex ante and ex post measures, respectively, there is a legitimate question of whether they can be compared at all.

Randall (1989) has offered a convenient solution to the entire dilemma posed by option value in a model that develops the concepts of total value and existence value (a component of nonuse value) under uncertainty from a strictly ex ante perspective. This result is achieved through the use of the planned expenditure function. The result of Randall's analysis is that total value can be divided into two subgroups - use values and existence values - regardless of whether uncertainty is present. Furthermore, Randall's approach

6 It is also possible that a change in streamflows could result in the destruction of downstream archaeological or cultural sites. 
holds considerable appeal to those who are interested in people's current perceptions of how future benefits would change (an ex ante valuation) as a result of implementing a particular policy today.

In summary, it is not possible to determine whether and to what extent demand and supply uncertainties may exist in the current study. In addition, the results of the analyses by Cory and Saliba (1987) and Randall (1989) suggest that the debate over option value is a moot point. Finally, although some studies have generated estimates of measures (including option price and option value), the results are suspect for a variety of reasons. Among these is the lack of a consistent set of definitions of such terms, suggesting that any effort at benefits transfer for these components of total value would be extremely suspect and difficult to support in a credible fashion. The conclusion is to ignore option values in the analysis that follows and to instead base estimates of the future values of the resource on consumer surplus measures. ${ }^{7}$ Freeman $(1984$, p. 1) has pointed out that "the actual consumer surplus of visitors to a national park can be interpreted as a sample estimate of the aggregate expected surplus of the universe of potential visitors."

\subsubsection{Nonuse Values}

Over time, various researchers have identified a number of different concepts for inclusion under the heading "nonuse values." These are bequest, preservation, altruistic, vicarious, and existence values. Of these, existence value and, to a lesser extent, bequest value have received the greatest amount of scrutiny. A number of papers (Madariaga and McConnell 1987; Smith 1987a; Randall 1989) present a logically consistent model that allows one to distinguish use values from existence values within a total valuation framework. There is some debate, however, over what elements should be included under the heading "existence value."

In a broad sense, existence value measures the value an individual attaches to the existence of a resource, even though the resource is not intended for personal use. In the present case, it is possible to assume that some individuals would be willing to pay a positive amount of money simply to know that sites such as the Flaming Gorge Recreation Area and the Grand Canyon would continue to exist in their current condition. In particular, individuals may attach positive values to the preservation of the existing ecology, historic and

7 It is important to note this approach is not recommended by Randall (1989, pp. 10-13), who states that "the optimism engendered by Cory and Saliba that ES [expected consumer surplus] can serve validly as a lower bound estimate of ex ante use value. . has been questioned by Smith's analyses of the noncomparability of EF [expected fair bet] (and OP [option price]) on the one hand and ES on the other. I conclude, for now, that there seem to be serious impediments to incorporating benefit measures based on revealed preference methods into a valid measure of ex ante total value. Again, however, there is little firm guidance as to the likely magnitude of the empirical errors that may be involved." 
prehistoric artifacts and sites, and current quality of recreational opportunities. Brookshire et al. (1986, p. 1514) argue that:

... [the] value associated with inherent characteristics of water resources seems to be the only motivation left out of all of those suggested as existence value that one might want to associate with a unique and different economic value associated with preserving water resources and that would not already have been characterized in the literature. If so, we suggest this is the relevant meaning of an economic existence value.

More recently, Rosenthal and Nelson (1992) have argued that although nonuse values (e.g., existence value) may exist, a number of problems raise serious questions about the legitimacy of including such values in the decision-making process. They point out that the range of possible existence values may be limitless and that accurate estimation of existence values is extremely difficult. The latter problem is attributed to the potential interaction between the method used to elicit the existence value attached to a particular good or resource and the value that is reported by the respondent. Rosenthal and Nelson $(1992$, p. 121) summarize their position as follows:

That people feel strongly about the state of the world can hardly be doubted. Yet, to recognize that happiness and well-being depend on the condition of other people and objects is not to say that these effects can or should be put into dollar terms. If existence value is to be measured for environmental resources, then it should also be measured for nonenvironmental goods and services. However, this could lead to an explosion of existence value claims, potentially creating a vast array of new benefits and costs to be applied for and against all kinds of programs. In practice, decisions to limit what qualifies for existence value and the way a survey instrument presents its information are likely to become a reflection of personal values and preferences, raising serious doubts with respect to the objectivity of economic determinations.

Proponents of the case for the inclusion of nonuse values in total valuation studies have offered strong rebuttals to the arguments described above. For example, a report prepared by HBRS, Inc. (1991, p. 17) contends that:

Motives based on feelings of environmental responsibility have to do with people's concerns about the effects of their consumption on environments that they do not personally plan to use. For example, if Gamma's consumption of electricity would contribute to deterioration of Grand Canyon beaches, then she might be willing to pay something to reduce or eliminate this effect so that she is not responsible for such harm. Bequest motives are a temporal extension of motives relating to benevolence toward relatives and other people in the temporal realm. ... If the benefactor's utility depends on the bequest, an additional value is created, and this 
additional value is missed if the beneficiary's use value alone is included in benefits.

As the preceding discussion suggests, although strong arguments have been made against including nonuse values in a total valuation study, inclusion is nonetheless justified on the basis of current economic thinking. Moreover, a growing body of evidence suggests that existence values, when measured as a percentage of use values, may be nontrivial. On the empirical side of the debate, the results of a number of studies suggest that nonuse values may account for a substantial portion of the total value of a resource. For example, Fisher and Raucher (1984) reviewed a number of studies that estimated use and nonuse values of particular resources. Fisher and Raucher (1984, p. 60) conclude that "nonuse benefits generally are at least half as great as recreational use benefits."

In deciding whether and, if so, how to include nonuse values in the current study, attention should focus on the policy change in question. A change in streamflows does not mean that the downstream resource would cease to exist. Rather, the quality of the resource would be altered. Thus, attention must focus on the marginal change in existence values attributable to this quality change. The point is that any possible change in existence values will be some fraction of the total existence value associated with the resource. A major question to arise is how this fraction might be estimated. The issue is addressed in Section 5. 


\section{EFFECTS OF STREAMFLOWS ON RECREATION AND NONUSE VALUES}

\subsection{OVERVIEW}

Streamflows serve a number of different purposes. They can be modified to accommodate the production of hydro-generated electricity. Instream flows are an input to recreational services that include boating, angling, picnicking, sightseeing, and hiking. Instream flows also influence various biological processes (e.g., the development of fisheries and the stability of riparian ecosystems). Finally, instream flows can affect access to geomorphic phenomena and cultural artifacts. By following the approach of Brown et al. (1991), the various effects of changes in instream flow can be categorized as either direct (short-term) or indirect (long-term) effects.

Direct effects are the effects of streamflows on specific recreational attributes such as angling success and boating travel time. A direct link exists between the quality of white-water boating (rafting, kayaking, canoeing) and angling and the level of instream flows. Instream flows can also affect the quality of activities such as camping, hiking, picnicking, and sightseeing. Similarly, short-term fluctuations in the level of streamflows may have a measurable effect on the quality of one or more of the activities just listed. Fluctuations in streamflows can also affect exposure to geomorphic phenomena and access to historic or cultural artifacts. For example, low flows may make it easier to travel along the shoreline and gain access to specific areas of interest. Higher flows may restrict this access and could inundate certain rock or mineral formations or cultural artifacts, including cave dwellings and art work (e.g., petroglyphs).

Indirect effects are the effects of streamflows on ecosystems and fish habitat. Instream flows and, more specifically, fluctuations in flows can have significant effects on riverine ecosystems. For example, the high flows found in most mountain streams in the spring act as a natural cleansing mechanism. High spring runoffs move debris downstream and flush out various types of stream-related vegetation. This scouring action is necessary to maintain the quality of trout fisheries and the rapids encountered by white-water enthusiasts. In addition, high flows help maintain clean sand and gravel bars used by campers and other recreationists. Lower flows that occur later in the season can improve the chances of survival for small fish.

Flows that are too high or too low can also have adverse effects on the ecosystem, especially as it relates to fisheries. Depending on the time of year, flows can drop off precipitously, leaving eggs and small fish "high and dry," or excessively high flows can scour spawning beds, reducing the size of the fishery. Excessively high flows can also permanently alter the stream bed and, in the process, eliminate rapids. Each outcome could be expected to reduce the quality and therefore the benefits of angling or boating. Variations in streamflow can also alter the riparian (stream-side) environment. Changes in streamflows may lead to significant changes in stream-side vegetation. Such changes could alter the quality of recreational activities, thereby affecting the benefits of such activities. 


\subsection{RELATIONSHIP BETWEEN STREAMFLOWS AND RECREATION}

Researchers have examined various aspects of the relationship between streamflows and recreational activities such as angling and boating. Although work in this area is far from complete, some general relationships have emerged. For example, a stable, generalizable relationship between streamflows and the quality of certain recreational activities appears to exist. In addition, the parameters of this relationship vary according to the recreational activity and site. These observations suggest that changes in streamflows can be expected to affect the WTP for each unit of a site-specific recreational experience and may alter the number of units consumed (i.e., a change in streamflow can affect both the quality and the quantity of recreation at a site).

The literature on the relationship between streamflows and recreation can be divided into three groups. The first group is primarily concerned with the relationship between the level of streamflows at a site and the perceived quality of various recreational activities. The second group addresses the question of how use rates might change in response to a change in streamflows. The third group attempts to estimate the economic value of individual recreational activities whose value is, in part, a function of the level of streamflows. Many studies fit into more than one of these three groups. This overlap is a reflection of the linkages among recreational quality, use rates, and economic value.

\subsubsection{Streamflow and the Quality of Recreation}

For boating and angling, a number of studies have concluded that at low flows, the quality of the recreational experience is positively related to increases in flows. However, most studies have found that at some point, a threshold flow level is reached. Beyond this threshold, further increases in streamflows diminish the quality of the recreational experience. Furthermore, this threshold varies across streams and activities (e.g., angling and boating). This latter observation indicates a tradeoff between angling and boating with respect to streamflows. To be specific, over some range of flows, as streamflows increase, the quality of angling decreases, but the quality of boating increases.

Shelby et al. (1992) conducted an extensive review of the literature on the relationship between streamflows and recreation. Of particular interest is a study involving the Dolores River in western Colorado (Vandas et al. 1990). The study included a survey of river users that addressed the relationship between streamflows and recreational quality. In the survey, respondents were asked to rate the quality of different flow levels on a fivepoint scale ranging from satisfactory to unsatisfactory. Figure 4 illustrates the relationship between these two variables for boating, which includes small and large rafts, kayaks, and canoes.

According to Figure 4, very low flows are considered unsatisfactory for the different types of boating covered by the study. Thus, beginning at very low flows, as flow levels increase, so does boater satisfaction (i.e., the quality of the experience increases). A threshold 


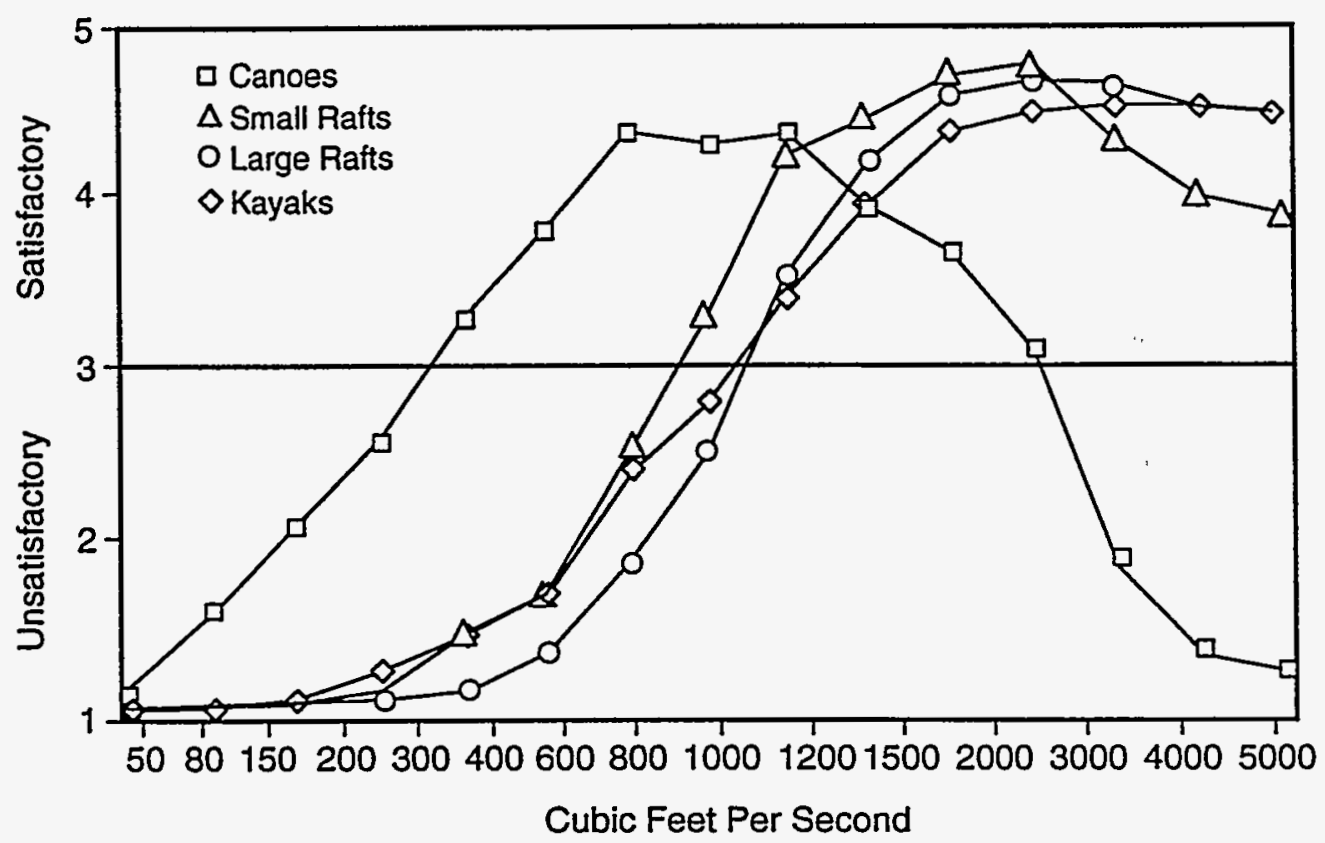

FIGURE 4 Relationship between Streamflows and Boater Satisfaction on the Dolores River (Sourcer Vandas et al. 1990)

exists, however, beyond which further increases in streamflows diminish the quality of the experience. For rafts, this threshold occurs at about 2,000 cubic feet per second (cfs). The threshold for canoeing is lower, occurring at about $800 \mathrm{cfs}$. There is a logical explanation for this change in the relationship: flows that are too high pose safety threats and may make it impossible to run large stretches of the river.

The relationship between boater satisfaction and streamflows was also examined in a study of white-water boating on the Colorado River below Glen Canyon Dam (Bishop et al. 1987). Part of the study included an attribute survey of river guides and trip leaders. Among other things, respondents were asked to rate the effect of different levels of streamflow on the quality of the boating experience. Although the specific flow level at which satisfaction is at a maximum differed from that found in the study by Vandas et al. (1990), the same general relationship between streamflows and boating quality was observed. (One would expect this threshold value for streamflows to vary across sites with other parameters, such as average width and depth.of the stream. In general, as the size of a stream increases, so will the volume of water considered adequate for boating.)

Bishop et al. (1987) also examined the relationship between flow rates and the quality of angling below Glen Canyon Dam. As in the case of white-water boating, increases in streamflows at initially low flow levels increase the quality of the angling experience. However, beyond a certain point, further increases in the level of streamflows reduce the quality of the experience. As streamflows increase, fish become more scattered and wading in the river becomes more difficult. Both of these factors reduce the quality of angling. 


\subsubsection{Streamflow and Use Rates}

Relatively few studies have attempted to estimate the empirical relationship between recreation use rates and changes in streamflows. Three identified in this review are Narayanan (1986), Ward (1987), and Duffield et al. (1992). In view of the findings reported by Vandas et al. (1990) and Bishop et al. (1987), one would expect the relationship between use rates and streamflows to be similar to that between the quality of the experience and streamflows. In general, the results of the three studies confirm that expectation.

The study by Narayanan (1986) examined the relationship between recreation and streamflows on the Blacksmith Fork River in northern Utah. By using information gathered from a survey of a randomly selected group of persons who visited the site in the summer of 1982, the study estimated the relationship between changes in streamflows and participation rates and between changes in streamflows and the economic value of recreation at the site. The survey respondents engaged in a variety of recreational activities, including camping, hiking, picnicking, and angling. No attempt was made to separate the effects of streamflows on any single activity.

The study's results indicate that as streamflows increase, participation rates should increase at an increasing and then a decreasing rate. A graph of this relationship appears as an S-shaped curve. Although part of the expected relationship was observed, the results did not indicate a threshold streamflow level beyond which participation rates would begin to decline. However, this result simply reflects the fact that the relationship was fitted to a logistic function. This choice of functional form was based on visual inspection of the data. The fact that the data appeared to fit this general form can be explained by at least two factors. The first is that some of the recreational activities engaged in by survey respondents (e.g., picnicking and hiking) are not directly affected by streamflows. There is a reduced likelihood that increases in streamflows would adversely affect participation rates for these activities relative to such activities as angling and boating. Second, the maximum streamflow considered in the study was encountered by many of the visitors included in the survey. (This latter observation is somewhat offset by the fact that streamflows encountered during the period in which the study was conducted were more than $150 \%$ of the seasonal average.) Thus, it is possible that further increases in streamflow could result in lowered participation rates.

In summary, because the study covered a range of activities including fishing but excluded boating, it is of limited value for the purposes of this analysis. Nonetheless, it provides evidence that over a range of streamflow levels, there is a positive relationship between streamflows and recreation use rates. Combined with the evidence on the relationship between streamflows and boater and angler satisfaction, it suggests that changes in streamflows may alter use rates for these activities.

The study by Ward (1987) provides additional evidence in support of the tentative conclusion just noted. This study examined the relationship between streamflows and the benefits from angling and white-water boating on the Rio Chama River, located in northern New Mexico. Part of the study consisted of a survey of randomly selected anglers and white- 
water boaters (rafters, kayakers, and canoeists) who visited the Rio Chama from May to August 1982. The survey respondents were shown a series of seven photographs depicting streamflows ranging from 50 to $4,000 \mathrm{cfs}$ and were asked if they would visit the site at each of the flows. For anglers, participation would increase with streamflows up to approximately $1,000 \mathrm{cfs}$. Beyond that point, further increases in streamflows would cause participation to decline. ${ }^{8}$ In the case of white-water boating, participation would be zero for flows below $800 \mathrm{cfs}$. Participation would increase for flows from 1,000 to 2,000 cfs, and decline as streamflows would increase to $4,000 \mathrm{cfs}$.

The results of the study by Ward are consistent with the expectation of the relationship between streamflows and recreation quality identified in the studies by Vandas et al. (1990) and Bishop et al. (1987). In addition, the data suggest that the change in the number of trips per capita resulting from a change in streamflows would not be negligible. According to the study results, over the 50 to 1,000 cfs range, a doubling of streamflows could cause angler participation rates to change by a range of 5-28\%. In addition, the higher percentage change in use rates is associated with higher baseline streamflows (i.e., a doubling of flows from 400 to $800 \mathrm{cfs}$ generated a larger percentage increase in use rates than did a doubling from 100 to $200 \mathrm{cfs}$ ). An increase in streamflows from 1,000 to 2,000 cfs was predicted to increase boater participation rates by more than $50 \%$.

A study by Duffield et al. (1992) examined the relationship between (1) changes in streamflows and WTP for recreational activities and (2) changes in streamflows and user participation rates. The study site consisted of sections of the Big Hole River and the Bitterroot River, both of which are located in Montana. Survey respondents included both anglers and nonanglers (i.e., individuals engaged in recreational activities other than angling). Eighty-seven percent of the respondents on the Big Hole River were anglers; on the Bitterroot River, the percentage fell to $47 \%$. This fact is important because the estimates of changes in participation rates and WTP attributable to changes in streamflow are not directly applicable to angling. Rather, these estimates are for a composite set of recreational activities.

The results of the analysis by Duffield et al. are consistent with the results of the other studies reviewed here. In particular, according to their results, participation rates are positively related to changes in streamflows up to a certain threshold value. Beyond that threshold, further increases in streamflows would result in a decrease in participation rates. For the Bitterroot River, over the range of flows between 50 and 1,100 cfs, a doubling of flows would cause participation rates to increase by a range of 4-12\%. For the Big Hole, over the range of flows between 50 and $1,850 \mathrm{cfs}$, a doubling of flows would cause participation rates to increase by a range of $6-25 \%$. Increases in flows beyond the respective thresholds would lead to a reduction in use rates at each site.

8 In the study, visitation rates were estimated for nine different origins. There was some variation in visitation rate patterns across origins. However, all but one of the origins exhibited the pattern described here. For the ninth site, visitation rates jumped from 0 to 15.7 per thousand capita between 1,000 and 2,000 $\mathrm{cfs}$ and remained at 15.7 at $4,000 \mathrm{cfs}$. 
While the figures reported above correspond closely to those reported in the study by Ward (1987) for angling, it is important to remember that more than angling is included in the latter study. In addition, the number of survey respondents was used as a proxy for use rates on the river sections included in the study. As the authors of the study point out, this could result in an underestimation of the level of actual use rates, which is likely to lead to upwardly biased estimates of the percentage change in use rates attributable to a percentage change in streamflows. (When an increment of a given size is measured as a percentage of some baseline value, the size of the percentage decreases as the baseline value increases.)

On the basis of existing evidence, one can assume that recreation use rates, especially for angling, are sensitive to changes in streamflows. For both angling and boating, use rates would decline dramatically (possibly to zero) if flows fall below some minimum threshold. In the case of the Green River in Dinosaur National Monument, for example, flows below $800 \mathrm{cfs}$ are considered inadequate for rafting (Section 5.2.2.1). Similarly, if flows fall below the minimum level required to support the fishery, angling rates would drop off.

\subsubsection{Streamflow and the Economic Value of Recreation}

Over the last 25 years, a large body of literature has developed suggesting that there are substantial economic benefits associated with water-related recreational activities (see in particular the review by Walsh et al. [1988]). In addition, a smaller group of studies has yielded evidence that the benefits from specific recreational activities such as white-water boating, fishing, hiking, and picnicking are highly correlated with average instream flows (see, for example, the review by Shelby et al. [1992]). On the basis of this evidence, a change in streamflows would cause a change in recreational user benefits as well.

A review of the results of specific studies of the relationship between recreational values and streamflows is presented in Section 4. However, it is worth considering the underlying relationships among such variables as WTP, the quality of recreational activities, and variations in streamflows. These relationships form the basis for the empirical estimates of the effects of a change in streamflows on the benefits, both regional and national, of waterbased recreation.

At a theoretical level, one would expect that a change in the level of streamflows would affect WTP for certain recreational activities such as angling and boating. This assertion rests on the observed relationship between changes in average streamflows and fluctuations in flows and the perceived quality of recreational activities. As noted in Section 2.2.1, WTP for recreation at a particular site is partly dependent on the quality of recreation at the site.

In the case of white-water boating (e.g., rafting, kayaking, and canoeing), streamflows contribute to the quality of rapids encountered along the waterway. At relatively low flows, the quality and availability of rapids are often reduced. This reduction translates into a reduction in the perceived quality of the boating experience. In economic terms, the 
result is a reduction in WTP and the net benefits of the experience. Similarly, streamflows that are relatively high may result in rapids that are too dangerous, thus reducing quality once again. Between these two extremes, increases in streamflows increase the quality of the experience. This results in an increase in WTP and the benefits of white-water boating. The review by Shelby et al. (1992) offers strong evidence in support of this conclusion.

Streamflows affect angling quality directly through effects on accessibility and catch rates and indirectly through effects on spawning and resulting fish populations. Extremely low flows increase fish mortality rates, resulting in reduced catch rates. In addition, low flows adversely affect boat fishing by rendering more areas on the stream inaccessible. Relatively high flows may make angling nearly impossible, especially for trout anglers who fish from shore. Widely fluctuating flows may inhibit angling to the extent of threatening angler safety. In addition, fluctuating flows can have adverse effects on the feeding patterns of fish and result in reduced catch rates for anglers.

Indirect effects tend to manifest themselves over a longer time period (Section 3.1). Flows that are too low or too high or fluctuate widely over short time periods may adversely affect spawning activities and the size of the sustainable fish population. More stable flows may have a positive effect on spawning and the size of the sustainable population. Changes in streamflows can also alter the riverine ecosystem and, in particular, the food base that supports the fishery. The quality of the fishery may deteriorate or improve, depending on how the environment is altered. Catch rates may be negatively or positively affected.

The indirect effects just noted may be reflected in estimates of the value anglers attach to different levels of streamflows. This will be the case only to the extent that such values are partly based on the effects of streamflow on fish populations and resulting current and expected future catch rates. What is most likely, in fact, is that this would not be the case. Existing benefits estimates are likely to be biased to the extent that the change in flows also affects the fish population, ceteris paribus. As in the case of white-water boating, evidence suggests that within a specified range of streamflows (which tends to vary across sites), the economic benefits from fishing are positively correlated to increases in streamflows.

\subsection{FLOW RATES AND NONUSE VALUES}

The value derived from recreation at a particular site is referred to as the use value of the resource (Section 2.3). Individual characteristics of the site (e.g., scenic beauty, crowding, and the level of streamflows) directly or indirectly affect total use value. The recreational use value of a resource, such as the section of the Green River between Flaming Gorge Dam and Jensen, Utah, is measured by the aggregate net WTP of recreationists who use the site. Similarly, the use value of an increment of streamflow is measured as the marginal WTP (i.e., the change in net benefits) associated with the change in streamflow, all else being constant. Because a change in streamflows affects WTP for recreation at a site, the recreational use value of the site will change as well. 
Strong theoretical and empirical evidence suggests that many resources have nonuse values in addition to use value. A nonuse value is independent of actual use of the resource. For example, individuals may be willing to pay some amount to preserve the Green River below Flaming Gorge Dam in its current condition, even though they do not plan to visit the site personally and may not be interested in the implications of preservation for recreational activity. In other cases, individuals may value preservation - and the concomitant opportunities afforded by preservation - for future generations.

A growing body of evidence suggests that a change of sufficient magnitude in streamflows could affect the use value of a resource. (This evidence is discussed at length in Section 4.) If the U.S. Bureau of Reclamation or Western changes dam operations in such a way that a change in streamflows occurs, total use values could change. ${ }^{9}$ However, it is much less clear how the same change in streamflows might affect nonuse values. There appears to be no direct evidence on the empirical relationship between a marginal change in one or more characteristics (e.g., streamflows) of a resource and nonuse benefits.

Because of a lack of empirical evidence concerning this issue, the effect of a change in streamflows on nonuse values should be considered. Begin by assuming that a segment of the population attaches positive nonuse value to the resources involved in this study. This assumption is based on the observation that each of the potentially affected sites possesses unique characteristics that, according to available evidence, hold positive nonuse value. Assume also that nonuse values are a function of the recreational, ecological, and aesthetic characteristics of each site. According to Sections 3.1 and 3.2, streamflows affect, both directly and indirectly, the quality of recreational activities at each site as well as the broader ecological and aesthetic site characteristics. According to these assumptions, one could conclude that if a change in dam operations increases (decreases) the quality of recreational or other attributes of a site, nonuse benefits could increase (decrease) as well. However, the effect on nonuse values depends on the effect that a change in streamflows has on each of these characteristics. These effects could offset each other. For example, a change in streamflows that reduces the amount of recreation could simultaneously benefit the resource by reducing crowding and the adverse effects caused by using the resource.

In summary, a change in streamflows could affect the benefits from recreational activities. In addition, nonuse benefits (existence and bequest values) could be affected. The extent of the changes in use and nonuse values depends directly on the actual change in dam operations and the resulting impacts on a variety of characteristics of the resource.

9 Even if use values do change, the direction of change is not clear a priori. This lack of clarity results from the fact that a change in streamflows that increases the quality of one recreational activity, such as white-water rafting, may simultaneously reduce the quality of another, like fishing (Bishop et al. 1987). Thus, there may be countervailing effects on the use values derived from each of these activities. 


\section{ANALYTICAL METHODS: REGIONAL ANALYSIS AND BENEFITS TRANSFER}

This section describes the approaches used to estimate economic impacts on recreation and nonuse values attributable to each of the operational scenarios. A number of issues are addressed, including (1) specific activities for which economic impacts were estimated, (2) the methods employed to estimate the magnitude of economic impacts, and (3) information needs of the impacts assessment.

\subsection{IMPACTS TO BE ESTIMATED}

The regional and national measures of the economic value of changes in recreation were considered. As discussed in Section 2.2.2, impacts are measured quite differently at these two levels. In particular, regional economic impacts are measured by changes in employment and income in the regional economy. Such changes are the result of changes in expenditures on goods and services (e.g., a decrease in the number of commercially provided raft trips on the Colorado River). Impacts at the national level are measured by changes in consumer surplus attributable to each policy. (Consumer surplus is measured as the difference between total WTP and the amount of actual expenditures on a good.)

At the national level, a variety of different recreational activities (and associated surplus values) ranging from sightseeing to hiking to white-water boating could be affected by a change in streamflows. On the basis of results of the literature review described in Section 3, recreation use values considered in the analysis were limited to nonmotorized boating - primarily white-water boating - and angling. This decision also has implications for the regional analysis, because regional impacts are effectively limited to those changes in boating (e.g., white-water boating) and angling-related expenditures, and corresponding multiplier effects, attributable to a change in streamflows.

\subsection{REGIONAL ECONOMIC IMPACTS: RECREATION AND TOURISM}

The impacts addressed in a regional economic impact analysis were reviewed in Section 2.2.2.1. Assessment of impacts at this level focuses on changes in employment and income within the affected region. For example, if the proposed action is expected to result in the creation of new jobs, the analyst attempts to predict the number of new jobs attributable to the policy option. In addition, the change in income resulting from the increased employment and spending in the regional economy is predicted.

Recreation and tourism at each of the affected sites contribute to the level of regional economic activity. An estimated 115,000 people annually visit the section of the Green River between Flaming Gorge Dam and the Colorado border. Another 10,000 to 12,000 people raft on the Green River through Dinosaur National Monument in a typical year. Visits at each site contribute to the local economy through purchases of a variety of goods and services 
including lodging, food, fuel, and expenditures on recreational services such as commercial white-water raft trips and fishing guide services. A change in the number of people visiting a site would result in a change in expenditures and therefore the level of regional economic activity.

The estimation of the impacts of a change in expenditures in the regional economy is based on the use of regional income, output, and employment multipliers. Total spending and output are disaggregated according to the sector of the economy (e.g., restaurants versus service stations) in which the spending occurs. Flows of goods and services between sectors of the economy are then used to estimate technical coefficients that reflect the extent to which changes in expenditures in one sector affect the level of economic activity in other sectors of the economy. One of the outputs of this modeling process is a set of multipliers that enables the analyst to predict the magnitude of the effect of a change in spending in one sector of the regional economy on total income in the region. A separate set of multipliers is calculated to estimate the change in total regional employment attributable to a change in expenditures in a particular sector.

For this analysis, estimation of the regional economic impacts of a change in recreational use rates at Flaming Gorge Dam was accomplished with the use of the IMPLAN regional economic model (Rose and Frias 1993). The regional economy was defined to include the following counties: Uintah and Daggett in Utah, Sweetwater and Uinta in Wyoming, and Moffatt and Rio Blanco in Colorado. Data were collected on average trip-related expenditures associated with angling and white-water boating and on use rates for each recreational activity (see Section 5). These data and projections of possible changes in use rates were then used to estimate the potential regional economic impacts of changes in streamflows resulting from changes in the operation of Flaming Gorge Dam. ${ }^{10}$

\subsection{NATIONAL ECONOMIC IMPACTS: USE AND NONUSE VALUES}

The theoretical measure of use and nonuse benefits within an economic framework was described in Section 2.2. To summarize that discussion, the economic benefit (i.e., net use value) of recreation at a site is measured as the difference between maximum WTP for recreation at the site and costs actually incurred. This difference is aggregated over all affected individuals to arrive at an estimate of the aggregate net benefits associated with recreation at the site. Nonuse value associated with a particular site is measured as the amount individuals would be willing to pay to ensure that the site is maintained in its current condition. Changes in recreation use values and changes in nonuse values are

10 The Glen Canyon EIS concluded that there would be no change in the number of white-water rafters or anglers. For white-water boating, this conclusion was based on the amount of excess demand for boating permits, regardless of streamflow conditions. In the case of angling, there was insufficient information to project the change in use rates attributable to a change in streamflows. According to this result, there should be no change in the amount of trip-related expenditures in the local economy. For this reason, there was no analysis of the regional economic impacts of a change in dam operations and streamflows at Glen Canyon Dam. 
measured as the difference between use values and nonuse values with and without the proposed change (e.g., a change in streamflows).

\subsubsection{Estimation Techniques}

The most direct approach to estimating the change in benefits attributable to a change in dam operations is to conduct a primary study at each affected site. One option is to use the contingent valuation method (CVM). In the CVM, a survey instrument is developed and administered to site users to collect primary data on variables including triprelated expenditures, maximum WTP for the trip, and various socioeconomic characteristics - sex, age, income, and so forth. The data are then analyzed to estimate average consumer surplus (i.e., net benefits) attributable to recreation at the site. ${ }^{11}$ The survey instrument also could be used to collect the data to estimate the nonuse values attributable to each site.

In terms of accuracy and reliability, collection and analysis of primary data are the preferred approach to estimation of the benefits of recreation at a particular site. However, this approach is both costly and time consuming. An alternative approach to benefits estimation is that of "benefits transfer." Benefits transfer entails the use of existing estimates of benefits at one site, commonly referred to as the "study site," to estimate the benefits of recreation at some other site, referred to as the "policy site."12 The stretch of river below Flaming Gorge Dam is a policy site. Because it has been the subject of a number of previous studies of the economic benefits of recreation, the area below Glen Canyon Dam is both a policy site and a study site.

\subsubsection{Major Issues in Benefits Transfer}

A number of different studies have addressed the issue of benefits transfer. In general, the studies have explored the potential for successful benefits transfers and the conditions that must be met. Boyle and Bergstrom (1992, p. 659) have proposed the following set of "idealistic" technical criteria: (1) the nonmarket commodity valued at the study site must be identical to the nonmarket commodity to be valued at the policy site, (2) the populations affected by the nonmarket commodity at the study site and the policy site must have identical characteristics, and (3) the assignment of property rights at both sites must lead to the same theoretically appropriate welfare measure (e.g., WTP versus willingness to accept compensation). It is important to emphasize that, as Boyle and Bergstrom note, these

11 The travel cost method (TCM) could also be used to estimate average net benefits. However, in a case involving the effects of changes in streamflows on net benefits, the TCM is more difficult to employ than the CV.M. For a more thorough discussion of the relative merits of the CVM and the TCM in this situation, see the discussion in Bishop et al. (1987, pp. 18-19).

12 The distinction between the term "study site" which is used to refer to the recreational resource for which benefits have been previously estimated, and "policy site" which refers to the site for which benefits estimates are needed was first introduced by Desvousges et al. (1992). This distinction will be employed throughout the remainder of the discussion presented here. 
are idealistic criteria. It is unlikely that each of these criteria would be met in practice. Nonetheless, they provide a benchmark for assessing the potential for successful benefits transfer in a specific situation.

\subsubsection{Comparability of the Study and Policy Sites}

Assuming that estimates of the benefits in question (e.g., consumer surplus per day for white-water rafters) are available, the first issue that must be addressed is the comparability of the study site(s) and the policy site. Of particular interest are the physical characteristics affecting the recreational experience of each site. In the case of white-water boating, streamflows are an extremely important characteristic. As discussed in Section 3, a significant correlation exists between the quality, and therefore benefits, of white-water boating and the level of streamflows at a site. However, the level of streamflows (measured, for example, in cfs) at which the quality of the experience is at a maximum varies across sites. For example, the quality of white-water boating on the Colorado River below Glen Canyon Dam reaches a maximum in the range of 29,000 to $33,000 \mathrm{cfs}$ (Bishop et al. 1987). In contrast, a study by Walsh et al. (1980) found that for four rivers in Colorado, value-maximizing flows occurred at approximately $2,000 \mathrm{cfs}$.

Other characteristics that should be considered in assessing the comparability of the study site and the policy site include accessibility to the site, the unique features of each site, and the availability of close substitutes should also be reduced. All else being constant, as accessibility decreases, congestion at a site should also be reduced. According to the study by Walsh et al. (1980), a negative relationship exists between the benefits of recreation at a site and the level of crowding. A decrease in accessibility could increase benefits by reducing crowding and enhancing the "wilderness" aspect of the experience.

The uniqueness of each site has a direct relationship to the potential for transferring the results of previous studies to other sites. This conclusion is based on the assumption that the benefits individuals derive from recreation at a specific site may be influenced, at least in part, by the unique characteristics of that site. For example, the results of an attributes survey conducted by Bishop et al. (1987) indicated that WTP for recreational activities below Glen Canyon Dam is at least partially influenced by the unique character of the Grand Canyon. In addition to providing excellent rapids, a trip down the Colorado River provides breathtaking scenery. It is reasonable to expect that individuals would be willing to pay more to raft in the Grand Canyon than they would to raft on another river that provides the same rapids and streamflow levels but no unique scenery. ${ }^{13}$

13 This observation notwithstanding, care must be taken when considering the Grand Canyon relative to other locations. It is true that the Grand Canyon is unparalleled in terms of its width and length and the variety of geological formations observed there. However, other sites, such as the Green River below Flaming Gorge Dam, are also considered by many people to be uniquely beautiful in their own right. 
In addition, the property of "uniqueness" is multidimensional. It is not simply a matter of assuming that the benefits of recreation below Glen Canyon Dam constitute an upper bound on the value of the same types of benefits (measured on a per person basis) at other sites. Indeed, it is possible that other characteristics, such as the quality of angling below Flaming Gorge Dam, may cause the benefits (measured on a per person basis) of angling there to exceed those for the area below Glen Canyon Dam.

An important determinant of the value of a recreation site is the availability of close substitutes. As the number or quality of good substitutes for a particular site increases, WTP for access to the site, and therefore surplus value, will decline. In the event that close substitutes are unavailable, a change in one or more site characteristics (e.g., streamflows) resulting in a reduction in the quality of a particular activity would most likely result in a corresponding loss of benefits. This would be the likely outcome of a decrease in the quality of recreation below Glen Canyon Dam and Flaming Gorge Dam.

The importance of the availability of close substitutes can be illustrated by referring to the Green River below Flaming Gorge Dam. A change in dam operations that alters flows in the Green River and adversely affects angling quality is likely to have effects at other nearby sites. For example, a change that reduces the quality of angling below Flaming Gorge Dam may lead to an increase in angling at substitute sites in southern Wyoming and western Colorado. The potential loss of benefits to anglers may be reduced relative to the loss that would occur if there were no close substitutes. However, the increase in demand at the other sites may result in increased congestion and reduce the quality and benefits of angling at these sites. The same types of tradeoffs are possible in the case of white-water boating. ${ }^{14}$

\subsubsection{Comparability of the Affected Populations}

Another set of variables to be considered in any benefits transfer is the comparability of the users of the study site and policy sites. Comparability is based on the socioeconomic and demographic characteristics of the users at each site. Factors such as average skill levels, average income, and average age of recreationists are all potential determinants of WTP for recreation at a site. Significant differences among user groups with respect to the variables just listed could adversely affect the potential for a successful benefits transfer.

14 The implications of the question of available substitutes is further illustrated by a recent court case involving a dispute between the State of Idaho and a trucking company (State of Idaho $v$. Southern Refrigerated Transport Inc.). The case involved the loss of recreational angling benefits attributable to a chemical spill (from an overturned truck) into the Little Salmon River in Idaho. In its ruling, the U.S. District Court of Idaho agreed that the quality of angling in this stretch of the river was adversely affected by the spill. However, the court also concluded that a close substitute for angling in the Little Salmon River (i.e., angling in the Salmon River) was readily available, and that this substitute served to offset the adverse effects of the spill on angling in the Little Salmon (Loomis 1991). 


\subsubsection{Analytical Methods Used at the Study Site}

The analytical methods used at the study site also have implications for the transferability of the resulting benefits estimates to other sites. For example, benefits estimated via the TCM are limited to use benefits only. By definition, it is not possible to estimate nonuse benefits via the TCM. In addition, as already noted, the TCM is not well suited to valuing such characteristics as incremental changes in streamflow. In this situation, the CVM is generally preferred. (The term "generally preferred" is used in deference to those who consider the CVM to be inapplicable under many or most circumstances because of potential biases that may be encountered during its use.)

Another factor that must be considered is the assumption regarding the distribution of property rights at both the study and policy sites. If the consumer is assumed to possess the property right to a good or service, or a characteristic of a recreation site such as streamflow level, willingness to accept compensation is the theoretically correct measure of benefits. However, if it is assumed that the consumer does not possess the property right in question, WTP is the theoretically correct measure of benefits. In fact, under certain conditions, willingness to accept and WTP are extremely close to each other (Willig 1976; Freeman 1979). Nonetheless, the approach used to estimate benefits at the study site may have important implications for the accuracy of the benefits when they are transferred to the policy site.

A final factor that must be considered is the range in benefits that was estimated at the study site. Depending on the estimation method employed (e.g., CVM versus TCM) and the types of questions employed in the survey instrument, benefits may reflect use values, nonuse values, or both.

\subsubsection{Options}

Benefits transfer can be more or less rigorous, depending on the available data and the needs of the policy analyst. For example, in some situations, benefits transfer amounts to the construction of back-of-the-envelope estimates that use averages from previous studies of use and nonuse values. This type of approach is acceptable in cases where the analyst requires a "ballpark" figure to determine whether further analysis is warranted. In other cases, provided there is sufficient information, empirical relationships estimated in previous studies may be applied to the policy site to generate estimates of consumer surplus. Once again, the choice of which approach to use depends on the needs of the analysts and the amount of available information.

\subsubsection{Use Values for Angling and Boating: Summary of Relevant Studies}

Over the past quarter century, researchers have estimated the economic value of various recreational activities. A large number of these studies have focused on the benefits of white-water boating and cold-water fishing. Subsequent analyses, most notably those by 
Walsh et al. (1988) and Smith and Kaoru (1990), have examined the similarities and differences among the benefits estimates reported in such studies. The primary objective of these latter efforts has been to identify the sources of observed differences in benefits estimates and the proportion of observed differences attributable to each source.

The study by Walsh et al. (1988) is of particular interest since it disaggregates benefits estimates according to the type of recreational activity in question (e.g., white-water boating versus cold-water fishing). Estimates are further disaggregated on a regional basis. In contrast, the study by Smith and Kaoru (1990) puts all water-based recreation activities - swimming, boating, and fishing - into a single category. Thus, although their results provide important insights into variations in benefits estimates derived from the use of the travel cost method, Smith and Kaoru do not address the questions of interest here.

\subsubsection{White-Water Boating}

Compared with the number of studies directed at the economic benefits of fishing, relatively few studies of the value of white-water boating have been done. Moreover, of the studies completed, only a subset constitute potential candidates for a benefits transfer. Included in this group are studies by Michaelson (1977), Rosenthal and Cordell (1984), Walsh et al. (1980), and Bishop et al. (1987).

One of the first studies attempting to estimate the economic value of white-water boating was conducted by Michaelson (1977). This study constitutes an important step in the development of the TCM. However, it has several shortcomings. First, estimates of consumer surplus are not disaggregated by individual type of recreational activity. Rather, figures are reported for broad-based types of recreation such as land-based versus waterbased recreation (where the latter includes fishing, different types of boating, and swimming). Second, the study does not consider the implications of alternative streamflow patterns on recreation use values. Thus, this study is not useful in this case.

Rosenthal and Cordell (1984) estimated demand curves for white-water boating on two rivers, the Upper Delaware and the Middle Fork of the Salmon River in Idaho. In addition to constructing a demand curve for each river, the authors also estimated consumer surplus per person per trip. However, there is no information on the average length of a trip, and no consideration was given to the impact that streamflows may have on demand for white-water boating. Consequently, this study was dropped as a potential candidate.

The study by Walsh et al. (1980) examines recreational activities including fishing, kayaking, and boating on nine rivers in western Colorado. In addition to estimating the effects of congestion on the demand for individual activities, the authors also estimated the relationship between changes in streamflows and the average consumer surplus per day for each activity. According to the study's results, assuming optimal use rates, average benefits per person per day for white-water boating on four rivers in western Colorado would range from $\$ 0.80$ (1978 $\$$ ) at 101 cfs to $\$ 9.93$ at 2,016 cfs. Adjusted to 1994 dollars, these figures increase to $\$ 1.63$ and $\$ 20.17$. 
In addition to estimating the effects of congestion on the demand for individual activities, Walsh et al. (1980) also estimated the relationship between changes in streamflow, measured as a percentage of bank-full conditions, and the average consumer surplus per day for boating. Given the close proximity of the study sites to the policy sites being considered here, and the types of questions addressed, this study appears to be a good candidate for use in a benefits transfer. However, the fact that the benefits estimates were conditioned on the optimal amount of congestion per stream mile would make transfer of the estimates to Flaming Gorge extremely difficult. This difficulty results from the lack of data on the concentration of anglers along the Green River. Given this lack of information, determining the likely direction of bias in the resulting estimates is not possible.

Bishop et al. (1987) conducted an attribute survey and contingent valuation survey of white-water boaters on the Colorado River below Glen Canyon Dam. The purpose of these surveys was to identify those aspects of the white-water boating experience that are most likely to influence the net benefits from the experience and to estimate the benefits from white-water boating and floating under different dam operations scenarios. According to the results of the attributes survey and contingent valuation survey that followed, the benefits of floating between the Dam and Lees Ferry are largely unaffected by changes in streamflows. It was concluded, therefore, that the use value of day boating (floating on this stretch of the river) would not change under a change in dam operations. ${ }^{15}$

For multiple-day white-water boating trips, the attributes survey revealed that boaters prefer constant flows, which are more consistent with natural conditions, to fluctuating flows. ${ }^{16}$ Assuming flows are constant, higher flows are preferred to lower flows over the range of $1,000 \mathrm{cfs}$ to approximately $33,000 \mathrm{cfs}$ (commercial boaters) and $29,000 \mathrm{cfs}$ (private boaters). In the case of fluctuating flows, higher flows are preferred to lower flows over the range of 5,000 to $25,000 \mathrm{cfs}$ for both groups. With respect to specific values, estimated net benefits ranged from a low of $\$ 62$ per trip ( $\$ 7$ per day) for commercial trips at 1,000 cfs to $\$ 1,179$ per trip ( $\$ 134$ per day) at 33,000 cfs. ${ }^{17}$ For private trips, net benefits range from a low of $\$ 28$ per trip ( $\$ 2$ per day) for commercial trips at 1,000 cfs to $\$ 903$ per trip (\$55 per day) at $29,000 \mathrm{cfs}$.

Bishop et al. (1987) also estimated the net benefits of white-water boating for a variety of streamflow alternatives. The. five streamflow alternatives covered constant,

15 Note, however, that a change in the number of people participating in day rafting would nonetheless cause the aggregate net benefits from this activity to increase or decrease.

${ }^{16}$ It is important to note that in the study by Bishop et al. (1987), flows were considered to be fluctuating flows as long as fluctuations exceeded 10,000 cfs. Flows with fluctuations smaller than $10,000 \mathrm{cfs}$ were described as steady flows.

17 All dollar values are in 1994 dollars. The values reported in Bishop et al. (1987) are in 1985 dollars. The adjustment to 1994 dollars was based on the change in the gross domestic product implicit price deflator between 1985 and 1992 (U.S. Department of Commerce 1993) and an assumed rate of inflation in 1993 of $2.78 \%$. 
moderate, and highly fluctuating flows and average monthly streamflows ranging from a low of $4,900 \mathrm{cfs}$ to a high of $25,000 \mathrm{cfs}$. Corresponding benefits estimates ranged from $\$ 50$ to $\$ 98$ per day (average $\$ 62$ ) for commercial boaters, and $\$ 23$ to $\$ 34$ per day (average $\$ 26$ ) for private boaters. In light of the characteristics of white-water boating trips in the Grand Canyon, these values could arguably be treated as an upper bound on the value of whitewater boating at other locations such as the Green River in Dinosaur National Monument.

\subsubsection{Angling}

Of the 287 benefits estimates reviewed by Walsh et al. (1988), 88 measured WTP for angling. Almost half (39) of these studies dealt with cold-water angling. According to their summary, average consumer surplus per day of cold-water angling is $\$ 30.62$ (1987 dollars), which translates to $\$ 37.85$ per day measured in 1994 dollars. This estimate is based on studies that collectively cover the majority of the United States. Some of the studies focus on specific sites (e.g., Colorado River below Glen Canyon Dam). Others provide estimates for specific states, including Wisconsin and Idaho. Finally, some of the studies present estimates of the benefits of cold-water angling averaged across sites throughout the United States. Walsh et al. (1988) also reported an estimate of the average consumer surplus per day for sites in the Rocky Mountain Region. On the basis of this smaller group of studies, average consumer surplus per day of trout fishing is $\$ 15.77$ (1987 dollars) in the Rocky Mountain Region. This figure increases to $\$ 19.49$ when measured in 1994 dollars. Further examination of these 39 estimates yielded two studies as candidates for a benefits transfer. These studies were selected on the basis of the characteristics discussed in Section 4.1.

The study by Walsh et al. (1980) examined the effects of streamflows and congestion in estimating the net benefits of trout fishing on three rivers in western Colorado. According to their results, if optimal use rates are assumed, average net benefits per person per day would range from $\$ 1.82$ (1978 dollars) at $40 \mathrm{cfs}$ to a maximum of $\$ 11.91$ at $524 \mathrm{cfs}$. Adjusted to 1994 dollars, these figures increase to $\$ 3.70$ and $\$ 24.19$. As in the case of white-water boating, the study estimated the relationship between changes in streamflow, measured as a percentage of bank-full conditions, and the average consumer surplus per day for angling. Given the close proximity of the study sites to the policy sites being considered here and the types of questions addressed, this study would appear to be a good candidate for use in a benefits transfer. However, the fact that the benefits estimates were conditioned on the optimal amount of congestion per stream mile would make transfer of the estimates to Flaming Gorge extremely difficult. This difficulty results from the lack of data on the concentration of anglers along the Green River. Given this lack of information, determining the likely direction of bias in the resulting estimates is not possible.

The study by Bishop et al. (1987) utilized a combination of attribute and contingent valuation surveys to estimate the benefits of trout angling on the Colorado River below Glen Canyon Dam and the factors that have the largest impact on benefits estimates. According to their results, benefits are sensitive to both the level and variations in streamflows. With 
respect to specific values, net benefits from trout fishing ranged from a low of $\$ 74$ per trip ( $\$ 29$ per day) at 1,000 cfs to $\$ 165$ per trip ( $\$ 66$ per day) at $10,000 \mathrm{cfs}$.

Bishop et al. (1987) also estimated the net benefits of trout angling for a variety of streamflow alternatives. The five alternative streamflow scenarios covered constant, moderate, and highly fluctuating flows and average monthly streamflows ranging from a low of $4,900 \mathrm{cfs}$ to a high of $25,000 \mathrm{cfs}$. Corresponding benefits estimates ranged from $\$ 42$ per day to $\$ 64$ per day (average $\$ 49$ ) for anglers. Considering the characteristics of trout fishing below Glen Canyon Dam, these values could arguably be treated as a lower bound on the value of trout angling on the Green River below Flaming Gorge Dam.

\subsubsection{Nonuse Values}

Compared with the amount of work that has been done on use values for recreational activities, there is relatively little information on nonuse values for various natural resource amenities. In addition, there is a problem with benefits transfer in that the unique site characteristics that account for nonuse values are likely to vary considerably across sites. Nonetheless, there is sufficient information to make some crude inferences about the likely magnitude of nonuse values for particular resources.

Fisher and Raucher (1984) reviewed a number of studies that estimated use and nonuse values of particular resources. They concluded that "nonuse benefits generally are at least half as great as recreational use benefits" (p. 60). A study by Loomis (1987) estimated that nonuse values were approximately 73 times as large as the corresponding use values associated with Mono Lake in California. This broad range indicates both the potential magnitude of nonuse values and difficulties that would be encountered in attempts to estimate nonuse values on the basis of existing studies. Because of the considerable variability in existing estimates of nonuse values and the lack of information on the effect that different operational scenarios could have on such values, no empirical estimates were attempted. Instead, observations on the potential effects on nonuse values were confined to qualitative assessments. 


\section{ESTIMATED ECONOMIC IMPACTS OF OPERATIONAL SCENARIOS}

\subsection{OVERVIEW}

Individuals engage in a variety of recreational activities, ranging from white-water boating, to angling, camping, hiking, and hunting, in the river corridors below Glen Canyon Dam and Flaming Gorge Dam. Of these activities, nonmotorized boating (primarily whitewater boating) and angling are most likely to be affected by a change in streamflows. ${ }^{18}$ Consequently, the remainder of this analysis focuses exclusively on the relationship between changes in streamflows and the quality and quantity of these forms of recreation. Characteristics other than streamflows, such as accessibility, the variety and extent of support facilities (e.g., beaches and boat ramps), and other factors that could affect the quality of a site in its role as a recreational resource would be unaffected by the different operational scenarios.

\subsection{SITE CHARACTERISTICS AND RECREATION USE RATES}

Expenditures on recreational activities at Glen Canyon Dam and Flaming Gorge Dam contribute to the level of activity in their respective local economies. A change in the number of recreationists visiting a site could cause the level of economic activity in the region to change. In addition, as noted in Section 1, a change in recreation use rates or a change in the quality of the resource and the experiences it provides could result in a change in the accrued benefits to users. Accordingly, information on visitation and recreation use rates is required to estimate the impacts of a change in streamflows on regional and national economic benefits.

\subsubsection{Glen Canyon Dam}

\subsubsection{General Characteristics}

Glen Canyon Dam is located in the southern reaches of Glen Canyon National Recreation Area (Glen Canyon NRA). The Colorado River flows for approximately 292 miles downstream from the dam through Grand Canyon National Park and into the headwaters of Lake Mead near Separation Canyon. Fishing and boating are the dominant recreational activities on the 15.5 mile segment of the Colorado River that begins at Glen Canyon Dam and terminates at Lees Ferry. (Lees Ferry is located at the confluence of the Paria and

18 The quality (and possibly quantity) of other activities such as sightseeing, picnicking, and hiking may also be influenced by streamflows. However, there is little available data on the extent of such activities at each site. More importantly, there is no information on how a change in streamflows would affect the quality or quantity of such activities. Therefore, it was not possible to include them in this analysis. 
Colorado Rivers on the border that separates Glen Canyon NRA from Grand Canyon National Park.) A major trout fishery is located upstream of Lees Ferry. Recreational facilities include 18 primitive beach campsites and a fully developed campground at Lees Ferry.

Boat access to the Colorado River in Glen Canyon NRA is limited to a dock below the dam and to the boat ramp at Lees Ferry. One-day raft trips usually launch from the dock. Use of the dock, however, is restricted to flows below 29,500 cfs (Bishop et al. 1987). At higher flows, rafters launch at Lees Ferry and motor upstream to a point near the dam before floating downriver. Anglers typically launch at Lees Ferry and move up and down the river according to fish migration patterns. The facilities at Lees Ferry are shared by users of Glen Canyon NRA and Grand Canyon National Park.

After leaving Glen Canyon NRA, the Colorado River flows westerly for 277 miles through the entire length of Grand Canyon National Park. One of the nation's most impressive and popular natural attractions, the park drew over 4 million visitors in 1991 (National Park Service [NPS] 1992). According to NPS estimates, approximately 10\% of all annual visitors engage in some activity below the canyon's rims (NPS 1985).

Recreational use in the affected area of Grand Canyon National Park is dominated by white-water boating. A nationally recognized white-water river, the Colorado in Grand Canyon National Park contains over 150 rapids. The prime white-water boating season is from May 1 through September 30. Access to the river is limited to a few trails (most notably Bright Angel and Kaibab) and to boat ramps at Lees Ferry, Diamond Creek, and Pearce Ferry. Lees Ferry is the launching point for trips down the river, while Diamond Creek and Pearce Ferry are usually used as extraction points.

On one level it could be argued that there are viable substitutes for recreation on the Colorado River below Glen Canyon Dam. For example, there are a number of other rivers that offer excellent angling opportunities, including the many gold medal trout streams in Colorado, and rivers such as the Green River below Flaming Gorge Dam in Utah. In addition, there are a number of streams to the west and east that offer excellent rapids for white-water rafters. However, the effect of the Grand Canyon significantly diminishes the relative attractiveness of many of these substitute sites. In addition to the unique character of the Grand Canyon, the spatial location of this site offers limited substitutes within a reasonable distance.

\subsubsection{Recreation Use Rates}

In 1991, almost 210,000 anglers, boaters, rafters, and hikers used the segment of the Colorado River between the Dam and Lees Ferry (Doland 1992). In addition, 19,427 commercial and 3,281 private passengers ran the river in Grand Canyon National Park for all or part of its length (Cherry 1992). The NPS limits white-water boating in Grand Canyon National Park to 169,950 user days per year. 


\subsubsection{Flaming Gorge Dam}

\subsubsection{General Characteristics}

Beginning at the spillway below Flaming Gorge Dam, the Green River flows east to the Utah-Colorado border. From there it enters the Brown's Park National Wildlife Refuge. The Green River then flows into Dinosaur National Monument and exits the Monument approximately 5 miles north of Jensen, Utah. This section of the Green River is approximately 85 miles long and supports a variety of recreational activities, including boating, angling, hiking, picnicking, and sightseeing. Boating and angling are particularly important activities, both in terms of the number of participants in each activity and their contribution to the local economy.

The availability of substitutes for recreation below Flaming Gorge Dam varies according to the type of recreation in question. For example, given the lack of challenging rapids, a number of other streams could serve equally well for white-water boating. This is especially true for the segment of the Green River that runs from Flaming Gorge Dam to the Colorado border. In addition, while the segment of the Green River that flows through Dinosaur National Monument offers a more challenging boating experience, there are numerous other streams in Colorado and Utah that have similar environmental characteristics (e.g., rapids and scenery).

Angling, however, is another matter. The trout fishery that has developed below Flaming Gorge Dam is considered to be of "blue ribbon" quality and offers some of the most outstanding trout angling in the western United States; fewer good substitutes exist. Therefore, it is reasonable to expect that the value of angling below Flaming Gorge Dam is higher than the average computed across all trout fisheries, and lies near, if not at, the upper end of the range of possible values.

Because of land use patterns along the Green River corridor, dividing the study section of the river into three sections is analytically appropriate. The first section consists of the 29 miles of the river between the spillway and the Utah-Colorado border. The second section is that portion of the river that flows through Brown's Park. The third is the section of the Green River located within the borders of the Dinosaur National Monument. Relative to the other two sections, there is very little recreational use of the river within Brown's Park. ${ }^{19}$ Therefore, this section was excluded from further consideration in the following analysis.

Green River from Flaming Gorge Dam to Utah-Colorado Border. The portion of the Green River extending from the spillway below Flaming Gorge Dam to the Utah-

19 According to NPS officials, there is a limited amount of boating and angling within the boundaries of Brown's Park, a wildlife refuge that includes the stretch of the Green River that lies between the Utah-Colorado border and the northern end of the Dinosaur National Monument (Carlson 1992). 
Colorado border is approximately 29 miles long. Individuals engage in a variety of recreational activities, including shore and boat angling, boating, hiking, and camping, on this stretch of the river. Economically, the quality of the fishery is an important factor in estimating the accrued benefits to anglers. This section of the river is considered a blue ribbon trout fishery. Consequently, the average benefits from angling in this section of the Green River would be expected to exceed the average benefits from angling at another location containing a fishery of lower quality.

This stretch of the Green River consists almost entirely of class I and class II rapids (only one class III rapid) and is suited primarily for novice boaters. Nonetheless, a change in streamflows could alter the quantity and quality of boating and therefore the net benefits accruing to the users of the resource.

According to a recent study of recreation on this section of the Green River (Pratt et al. 1991), the peak use times for angling and boating are fairly distinct. There are two peak angling seasons: April to mid-June and Labor Day through October. The peak boating season extends from mid-June through Labor Day. The effect of a change in streamflows on recreation is likely to be concentrated in one activity, depending on the time of year.

Green River in Dinosaur National Monument. The NPS administers the Dinosaur National Monument (DNM). Although visitors to the DNM engage in a variety of activities, recreation on the Green River within the Monument's boundaries is confined primarily to boating. A limited amount of trout angling exists, as does some fishing for catfish in the lower reaches of the Monument area. (Jones Creek, which feeds into the Green River within the Monument, is a "choice" trout stream. However, Jones Creek is unaffected by flows in the Green River.) However, angling is of minimal importance within the DNM (Carlson 1992), and the angling that does occur is relatively insensitive to changes in river hydrology.

Boating in the DNM takes place on both the Green River and the Yampa River, which flows from east to west and joins the Green near the center of the Monument region. Both rivers offer class II and class III rapids. The primary or high-use boating season within the DNM is from early May to mid-September. River running on the Yampa is limited to the early part of the season. The Yampa historically becomes unrunnable by mid-July because of low flows.

In recent years, the average flow rate in the Green River within the DNM has been approximately $800 \mathrm{cfs}$. Flows below $800 \mathrm{cfs}$ would eliminate most of the demand for boating on the Green River since the river is essentially impassable at lower flows (Carlson 1992). However, since the Yampa is still a natural flow river, rafters could run the Yampa and then run the Green to Split Mountain in the spring and early summer. Flows below 800 cfs on the Green would reduce the quality of the experience.

To run the river within the Monument, individuals must either go through a commercial outfitter or receive a permit for a private raft trip. In 1992, 11 commercial outfitters were authorized to undertake a combined total of 200 launches during the high-use 
season. An equal number of permits for private launches is distributed through a lottery that is conducted during January of each year. During the high-use season, a total of four rafts are allowed on either river each day, and the combined total on the two rivers is limited to six rafts. Commercial launches usually involve 15 to 20 people, while the average for private launches is somewhat lower. The NPS also authorizes a limited number of "special population" trips for handicapped individuals and people engaged in various forms of therapy.

\subsubsection{Recreation Use Rates}

Green River from Flaming Gorge Dam to Utah-Colorado Border. Table 1 summarizes recent use statistics for angling and boating, the two most important activities on this segment of the Green River. As the data indicate, shore angling is the most important activity. Together, shore and boat angling accounted for an estimated 104,650 user days in 1991. These figures reflect a large surge in the popularity of trout angling on the Green River, resulting from the implementation of regulations in 1985 designed to improve the quality of the sport (Pratt et al. 1991). The data in Table 1 indicate that boating (nonangling) is far less important than angling as a primary activity.

Green River in Dinosaur National Monument. Table 2 summarizes boater use statistics for the years indicated. Although raft trips can begin on both the Green and the Yampa, all trips ultimately end on the Green, usually at the take-out at Split Mountain. In addition, the majority of all trips begin at the put-in located upstream from the Gates of Lodore. Thus, although the data in Table 2 are a combination of use rates for both rivers, they are applicable to an analysis of the effects of a change in flows in the Green River since nearly everyone who rafts within the Monument spends at least some amount of time on the Green. According to the data in Table 2, boating user days in DNM fell by approximately

TABLE 1 Green River Spillway to Colorado Border: Recreation Use Data for Angling and Boating

\begin{tabular}{ccccc}
\hline Year & $\begin{array}{c}\text { Total } \\
\text { Visitor } \\
\text { Days }\end{array}$ & $\begin{array}{c}\text { Boating } \\
\text { Angler }_{\text {User Days }^{\text {a }}}\end{array}$ & $\begin{array}{c}\text { Shore } \\
\text { Angler } \\
\text { User Days }^{\text {a }}\end{array}$ & $\begin{array}{c}\text { Nonangler } \\
\text { Boating } \\
\text { User Days }^{\mathrm{a}}\end{array}$ \\
\hline 1989 & 114,000 & 30,780 & 72,960 & 5,700 \\
1990 & 114,000 & 30,780 & 72,960 & 5,700 \\
1991 & 115,000 & 31,050 & 73,600 & 5,750 \\
\hline
\end{tabular}

a Estimated number of user days for each activity was calculated as "a" (i.e., total number of visitors), where "a" is the percentage of survey respondents indicating activity as most important. For shore angling, $a=0.64$; for boat angling, $\mathrm{a}=0.27$; for nonangling boating, $\mathrm{a}=0.05$.

Source: Pratt et al. (1991, Table 11, p. 76); Sams (1992). 
TABLE 2 Green River in Dinosaur National Monument: Recreation Use Data for Boating

\begin{tabular}{ccrrrrrr}
\hline & \multicolumn{7}{c}{ Boater User Days } \\
\cline { 2 - 8 } Year & Total & May & June & July & August & September & Other $^{\mathrm{a}}$ \\
\hline & & & & & & & \\
1988 & 37,446 & 6,689 & 10,549 & 8,605 & 7,453 & 2,385 & 1,765 \\
1989 & 33,263 & 7,114 & 10,512 & 6,242 & 5,724 & 1,945 & 1,726 \\
1990 & 34,899 & 7,140 & 9,994 & 7,617 & 6,518 & $1,818^{\mathrm{b}}$ & $1,812^{\mathrm{b}}$ \\
1991 & $\mathbf{3 5 , 7 0 4}$ & 6,363 & 10,572 & 8,285 & 6,189 & 2,183 & 2,112 \\
\hline
\end{tabular}

a Category consists of visitation in March, April, October, and November.

b Estimate based on historical average.

Source: Carlson (1992).

$11 \%$ between 1988 and 1989. Since that time, use rates have risen steadily toward their former levels. The monthly distribution of use rates has also remained fairly stable.

According to NPS records, total boater days have remained fairly constant over the last 20 years (Carlson 1992). This regularity reflects the fact that the demand for permits to run the rivers has historically exceeded the available supply. From 1982 to 1987, noncommercial applications for permits to run the river during the high-use season averaged approximately 2,000 per year (only 200 launches are permitted each season). In 1990, this figure rose to just fewer than 3,000, and in 1991 the number of permit applications was slightly more than 3,000. On the basis of these data, a change in flows on the Green River could be revealed as a quality effect in the analysis of the economic impacts of the flow change. However, it is important to keep in mind that for flows below $800 \mathrm{cfs}$, demand would probably fall by a large percentage over time, resulting in effects on both quantity and quality.

\subsection{REGIONAL ECONOMIC IMPACTS}

\subsubsection{Glen Canyon Dam}

According to Bishop et al. (1987), the demand for permits to raft the Colorado River below Glen Canyon Dam far exceeds the available supply. In addition, there is no evidence to suggest that angling use rates would be substantially altered by a change in flow regimes below the dam. The conclusion is that there would be no change in boating or angler user days as a result of a change in dam operations. Since use rates normally remain constant, recreation-related expenditures in the local economy should remain unchanged as well. No estimation of regional economic impacts attributable to changes in recreation use rates and expenditures is given. However, recreation-related expenditures are estimated to account for 
approximately $\$ 24$ million per year (1994 \$) in the local economy around Glen Canyon Dam (Reclamation 1995).

\subsubsection{Flaming Gorge Dam}

To estimate employment and output impacts of recreation below Flaming Gorge Dam, it is necessary to identify those expenditures in the local economy that are linked to affected recreational activities (i.e., white-water boating and angling). Recreationists spend large sums of money on a variety of items ranging from food and lodging to sophisticated types of equipment (e.g., boats, fishing tackle, and specialty clothing) to services of professionals such as fishing guides and raft operators. However, some of the expenditures associated with recreational activities are more likely to occur in the local economy, while others are more likely to occur outside of the region. Additionally, some types of expenditures are more closely related to individual trips to a site. Other expenditures, such as purchases of equipment, are more closely tied to the decision to partake in a particular recreational activity and are not easily linked to any single trip.

Most nonresidents (i.e., recreationists not residing within the boundaries of the regional economy) who visit a particular site are likely to already own durable items such as boats and fishing tackle. Other things being equal, including estimates of expenditures on these items, this situation would lead to an overstatement of the regional economic impacts of a change in recreation use rates. Similarly, most expenditures by residents on durable items are probably not attributable to a single trip. Furthermore, if a change at a particular site results in a reduction in use rates at the site, substitution of a different site within the region should leave such expenditures relatively unchanged. Nonetheless, some expenditures for durable items do occur in the regional economy as a result of a visit to a particular site. According to the study by Pratt et al. (1991), individuals reported equipment-related expenditures in the regional economy on their trip to the Green River. Thus, the decision was made to include the following expenditures in the regional analysis: (1) expenditures for equipment identified by survey respondents in the Pratt et al. (1991) study and (2) expenditures for nondurable goods and services (i.e., trip-related expenditures).

Table 3 summarizes average expenditures for goods and services that boaters and anglers are likely to purchase in the local economy. These items include food, lodging, transportation costs (e.g., fuel), camping fees, equipment, and other miscellaneous expenses. The data in Table 3 represent average expenditures by anglers and boaters in Utah and Colorado. The expenditures data for Utah boaters are applicable to changes in use rates on the Green River below Flaming Gorge Dam. The expenditures data for Colorado boaters are applicable to projected changes in use rates on that portion of the Green River that flows through the DNM. The data on trip-related expenditures by anglers in Utah are applicable to changes in angler use rates on the Green River below Flaming Gorge Dam. 
TABLE 3 Green River: Recreation-Related Expenditures per Person/Day (1990 \$)

\begin{tabular}{|c|c|c|c|}
\hline \multirow[b]{2}{*}{ Category } & \multirow{2}{*}{$\frac{\text { Angling (\$) }}{U_{\text {tah }}{ }^{\mathrm{a}}}$} & \multicolumn{2}{|c|}{ Boating (\$) } \\
\hline & & $\mathrm{Utah}^{\mathbf{b}}$ & Colorado $^{c}$ \\
\hline Transportation & 20 & 14 & 7 \\
\hline Food and beverages & 17 & 11 & 12 \\
\hline Lodging & 17 & 11 & 5 \\
\hline Equipment rental & 3 & 2 & $\cdots$ \\
\hline Guide service & 13 & - & $53^{d}$ \\
\hline Fishing tackle & 7 & - & - \\
\hline Other & 3 & 2. & 1 \\
\hline Total & 80 & 40 & 78 \\
\hline
\end{tabular}

a Source: Pratt et al. (1991). For the derivation of these data, see Table A.1. These data are for the stretch of the Green River that runs from the Spillway to the Colorado-Utah border.

b Source: Pratt et al. (1991). For the derivation of these data, see Table A.2. These data are for the stretch of the Green River that runs from the Spillway to the Colorado-Utah border.

c Source: Public Information Corporation (1986) (unless otherwise noted). These data are for the stretch of the Green River that runs through Dinosaur National Monument. Figures were converted to 1990 dollars by using the GDP implicit price deflator.

d Source: Published rates for commercially guided raft trips through Dinosaur National Monument in 1992. Average cost per person per day was reduced by half to reflect even split between commercial and private raft trips on this portion of the Green River. Figure was adjusted to 1990 dollars by using the GDP implicit price deflator.

e Category includes license fees, shuttles, gear, and camping fees.

Although it is possible to state qualitatively the effects of each scenario on recreation, data on the relationship between streamflows and use rates are insufficient to estimate changes in use rates attributable to each scenario. Therefore, it was not possible to estimate the regional economic impacts of each of the operational scenarios considered in Section 5.4.2. However, it is still possible to gain insights into the potential effects each scenario could have on the level of activity in the local economy. On the basis of data on use rates and expenditures reported in Tables 1-3, angling, day floating, and white-water boating on the Green River between Flaming Gorge Dam and Jensen, Utah, accounted for \$24.8 million 
(1994 dollars) of output in the local economy in 1991. (The local economy around the Green River below Flaming Gorge Dam was defined to include Uintah and Daggett counties in Utah, Sweetwater and Uinta counties in Wyoming, and Moffat and Rio Blanco counties in Colorado [Rose and Frias 1993].) In addition, these activities resulted in an estimated $\$ 12.6$ million of personal income and approximately 573 jobs (Rose and Frias 1993). (The estimates presented in Rose and Frias [1993] were adjusted on the basis of the use rates reported in Table 1.) These figures amount to $0.22 \%, 0.22 \%$, and $0.38 \%$ of total output, income, and employment in the six-county region in the same year. If all three of these recreational activities were eliminated, output, income, and employment would decline by the percentages noted above. (This calculation assumes that use rates are relatively stable over time. This assumption is supported by recent data; Tables 1-3.) However, even in the worst-case operation scenario (i.e., year-round high fluctuating flows), use rates would probably decline by considerably less than $100 \%$. In turn, regional economic impacts would decline when compared with the extreme case noted above. For example, if use rates for each of the three activities were to fall by $50 \%$, output, income, and employment would fall by $0.1 \%, 0.1 \%$, and $0.2 \%$. Similarly, a $10 \%$ decrease in use rates would cause the same three measures of economic activity to decline by $0.02 \%, 0.02 \%$, and $0.04 \%$. (Note that an increase in use rates would result in an increase in output, income, and employment. The amount of change in each variable would depend on the change in each of the three use rates.)

\subsection{RECREATION USE VALUES}

\subsubsection{Glen Canyon Dam}

The study by Bishop et al. (1987) produced strong evidence that changes in the use value of recreation would change as streamflows change. According to their results, the use values of white-water boating and angling increase as the degree of daily fluctuations in streamflows decreases. In addition, use values for angling reach a maximum at a flow level considerably less than the flow level required to maximize the value of white-water boating. However, considering the structure of the questions used in their study, inferences on the effects of fluctuations in streamflows were limited to fluctuations greater than or less than $10,000 \mathrm{cfs}$. As a result, it was not possible to distinguish between certain operational scenarios. In addition, recreation values were limited to angling and commercial and private white-water boating, since these were the activities found to be most sensitive to changes in streamflows.

The results of the study by Bishop et al. (1987) were the basis for estimates of the net economic value of recreation for each of the operational scenarios at Glen Canyon Dam. The values reported for each of the operational scenarios discussed below are summarized in Table 4. These values were all taken from the Glen Canyon EIS (Reclamation 1995). 
TABLE 4 Summary of Recreation Use Values Associated with Each Operational Scenario at Glen Canyon Dam

\begin{tabular}{|c|c|c|c|c|c|c|}
\hline \multirow[b]{2}{*}{$\begin{array}{l}\text { Operational Scenario/ } \\
\text { Hydrological Condition }\end{array}$} & \multicolumn{5}{|c|}{ Use Value by Recreational Activity $\left(10^{6} 1994 \$\right)$} & \multirow[b]{2}{*}{$\begin{array}{c}\text { Percent } \\
\text { Change from } \\
\text { Historical } \\
\text { Flows } \\
\end{array}$} \\
\hline & Angling & $\begin{array}{c}\text { Commercial } \\
\text { White- } \\
\text { Water } \\
\text { Boating }\end{array}$ & $\begin{array}{l}\text { Private } \\
\text { White- } \\
\text { Water } \\
\text { Boating }\end{array}$ & $\begin{array}{l}\text { White-Water } \\
\text { Boating below } \\
\text { Diamond } \\
\text { Creek }\end{array}$ & Total $^{\mathrm{a}}$ & \\
\hline \multicolumn{7}{|l|}{ Historical flows } \\
\hline Dry & 1.4 & 5.7 & 1.2 & 0.11 & 8.41 & - \\
\hline Moderate & 1.3 & 6.7 & 1.3 & 0.13 & 9.43 & - \\
\hline Wet ${ }^{b}$ & 1.2 & 11.9 & 1.9 & 0.26 & 15.26 & - \\
\hline \multicolumn{7}{|l|}{$\begin{array}{l}\text { Maximum power plant } \\
\text { capacity flows }\end{array}$} \\
\hline Dry & 1.4 & 5.7 & 1.2 & 0.11 & 8.41 & 0.00 \\
\hline Moderate & 1.3 & 6.7 & 1.3 & 0.13 & 9.43 & 0.00 \\
\hline Wet & 1.2 & 11.9 & 1.9 & 0.26 & 15.26 & 0.00 \\
\hline \multicolumn{7}{|l|}{$\begin{array}{l}\text { Restricted high } \\
\text { fluctuating flows }\end{array}$} \\
\hline Dry & 1.4 & 5.7 & 1.2 & 0.11 & 8.41 & 0.00 \\
\hline Moderate & 1.3 & 6.7 & 1.3 & 0.13 & 9.43 & 0.00 \\
\hline Wet & 1.2 & 11.9 & 1.9 & 0.26 & 15.26 & 0.00 \\
\hline \multicolumn{7}{|l|}{$\begin{array}{l}\text { Moderate fluctuating } \\
\text { flows }\end{array}$} \\
\hline Dry & 1.6 & 5.5 & 0.9 & 0.10 & 8.10 & -0.04 \\
\hline Moderate & 1.3 & 6.7 & 1.3 & 0.13 & 9.43 & 0.00 \\
\hline Wet & 1.2 & 11.9 & 1.9 & 0.22 & 15.22 & 0.00 \\
\hline \multicolumn{7}{|l|}{ Modified low } \\
\hline \multicolumn{7}{|l|}{ fluctuating flows } \\
\hline Dry & 1.9 & 6.6 & 1.1 & 0.12 & 9.72 & 15.58 \\
\hline Moderate & 1.4 & 9.6 & 1.7 & 0.18 & 12.88 & 36.59 \\
\hline Wet & 1.2 & 14.0 & 2.2 & 0.26 & 17.66 & 15.73 \\
\hline \multicolumn{7}{|l|}{$\begin{array}{l}\text { Interim low } \\
\text { fluctuating flows }\end{array}$} \\
\hline Dry & 1.9 & 7.0 & 1.2 & 0.13 & 10.23 & 21.64 \\
\hline Moderate & 1.8 & 9.9 & 1.8 & 0.18 & 13.68 & 45.07 \\
\hline Wet & 1.4 & 14.1 & 2.2 & 0.26 & 17.96 & 17.69 \\
\hline \multicolumn{7}{|l|}{$\begin{array}{l}\text { Existing monthly } \\
\text { volume steady flows }\end{array}$} \\
\hline Dry & 1.9 & 7.0 & 1.2 & 0.13 & 10.23 & 21.64 \\
\hline Moderate & 1.8 & 9.9 & 1.8 & 0.18 & 13.68 & 45.07 \\
\hline Wet & 1.4 & 14.1 & 2.2 & 0.26 & 17.96 & 17.69 \\
\hline \multicolumn{7}{|l|}{$\begin{array}{l}\text { Seasonally adjusted } \\
\text { steady flows }\end{array}$} \\
\hline Dry & 1.8 & 7.1 & 1.1 & 0.13 & 10.13 & 20.45 \\
\hline Moderate & 1.7 & 10.4 & 1.9 & 0.20 & 14.20 & 50.58 \\
\hline Wet & 1.4 & 13.5 & 2.2 & 0.26 & 17.36 & 13.76 \\
\hline
\end{tabular}


TABLE 4 (Cont.)

\begin{tabular}{|c|c|c|c|c|c|c|}
\hline \multirow[b]{2}{*}{$\begin{array}{l}\text { Operational Scenariol } \\
\text { Hydrological Condition }\end{array}$} & \multicolumn{5}{|c|}{ Use Value by Recreational Activity $\left(10^{6} 1994 \$\right)$} & \multirow[b]{2}{*}{$\begin{array}{c}\text { Percent } \\
\text { Change from } \\
\text { Historical } \\
\text { Flows }\end{array}$} \\
\hline & Angling & $\begin{array}{c}\text { Commercial } \\
\text { White- } \\
\text { Water } \\
\text { Boating }\end{array}$ & $\begin{array}{l}\text { Private - } \\
\text { White- } \\
\text { Water } \\
\text { Boating }\end{array}$ & $\begin{array}{l}\text { White-Water } \\
\text { Boating below } \\
\text { Diamond } \\
\text { Creek }\end{array}$ & Total $^{\mathrm{a}}$ & \\
\hline \multicolumn{7}{|l|}{$\begin{array}{l}\text { Year-round steady } \\
\text { flows }\end{array}$} \\
\hline Dry & 2.0 & 6.1 & 1.1 & 0.12 & 9.32 & 10.82 \\
\hline Moderate & 1.7 & 10.4 & 1.9 & 0.20 & 14.20 & 50.58 \\
\hline Wet & 1.4 & 13.6 & 2.3 & 0.26 & 17.56 & 15.07 \\
\hline \multicolumn{7}{|c|}{ a Values in rows may not sum to total due to rounding. } \\
\hline \multicolumn{7}{|c|}{$\begin{array}{l}\text { b The values reported for wet hydrological conditions are a simple arithmetic average of the three values } \\
\text { for wet years reported in the Glen Canyon EIS. }\end{array}$} \\
\hline
\end{tabular}

Historical Flows. For this scenario, assuming moderate hydrological conditions, the use values of angling, commercial white-water boating, private white-water boating, and white-water boating below Diamond Creek would be approximately $\$ 1.3$ million, $\$ 6.7$ million, $\$ 1.3$ million, and $\$ 0.13$ million, or a total of $\$ 9.43$ million. Dry hydrological conditions would yield use values for each of these activities of $\$ 1.4$ million, $\$ 5.7$ million, $\$ 1.2$ million, and $\$ 0.11$ million, or a total of $\$ 8.41$ million. Assuming wet hydrological conditions, the corresponding values would be $\$ 1.2$ million, $\$ 11.9$ million, $\$ 1.9$ million, and $\$ 0.26$ million, or a total of $\$ 15.26$ million.

Maximum Power Plant Capacity Flows. This operational scenario would result in the same average daily release as historical flows. In addition, maximum fluctuations could exceed 10,000 cfs in both scenarios. Consequently, the recreational impacts would be the same. (This conclusion results from the inability of the model developed by Bishop et al. [1987] to distinguish between the flow regimes associated with these two operation scenarios.)

Restricted High Fluctuating Flows. This operational scenario would result in the same average daily release as historical flows. In addition, maximum fluctuations could exceed $10,000 \mathrm{cfs}$ in both scenarios. Consequently, the recreational impacts would be the same.

Moderate Fluctuating Flows. Under this operational scenario, assuming moderate hydrological conditions, the use values of angling, commercial white-water boating, private white-water boating, and white-water boating below Diamond Creek would be 
approximately $\$ 1.3$ million, $\$ 6.7$ million, $\$ 1.3$ million, and $\$ 0.13$ million, or a total of $\$ 9.43$ million. Assuming dry hydrological conditions, the use value of each of these activities

Modified Low Fluctuating Flows. Under this operational scenario, assuming moderate hydrological conditions, the use values of angling, commercial white-water boating, private white-water boating, and white-water boating below Diamond Creek would be approximately $\$ 1.4$ million, $\$ 9.6$ million, $\$ 1.7$ million, and $\$ 0.18$ million, or a total of $\$ 12.88$ million. Assuming dry hydrological conditions, the use value of each of these activities would be $\$ 1.9$ million, $\$ 6.6$ million, $\$ 1.1$ million, and $\$ 0.12$ million, or a total of $\$ 9.72$ million. Wet hydrological conditions would yield corresponding values of $\$ 1.2$ million, $\$ 14.0$ million, $\$ 2.2$ million, and $\$ 0.26$ million, or a total of $\$ 17.66$ million.

Interim Fluctuating Flows. Under this operational scenario, assuming moderate hydrological conditions, the use values of angling, commercial white-water boating, private white-water boating, and white-water boating below Diamond Creek would be approximately $\$ 1.8$ million, $\$ 9.9$ million, $\$ 1.8$ million, and $\$ 0.18$ million, or a total of $\$ 13.68$ million. Assuming dry hydrological conditions, the use value of each of these activities would be $\$ 1.9$ million, $\$ 7.0$ million, $\$ 1.2$ million, and $\$ 0.13$ million, or a total of $\$ 10.23$ million. Wet hydrological conditions would yield corresponding values of $\$ 1.4$ million, $\$ 14.1$ million, $\$ 2.2$ million, and $\$ 0.26$ million, or a total of $\$ 17.96$ million.

Existing Monthly Volume Steady Flows. This operational scenario would result in the same average monthly flows as low fluctuating flows. In addition, maximum fluctuations would be less than $10,000 \mathrm{cfs}$ in both scenarios. Consequently, the recreational impacts would be the same.

Seasonally Adjusted Steady Flows. Under this scenario, assuming moderate hydrological conditions, the use values of angling, commercial white-water boating, private white-water boating, and white-water boating below Diamond Creek would be approximately $\$ 1.7$ million, $\$ 10.4$ million, $\$ 1.9$ million, and $\$ 0.20$ million, or a total of $\$ 14.2$ million. Dry hydrological conditions would yield use values of $\$ 1.8$ million, $\$ 7.1$ million, $\$ 1.1$ million and $\$ 0.13$ million for each of these activities, or a total of $\$ 10.13$ million. Under wet hydrological conditions, the corresponding values would be $\$ 1.4$ million, $\$ 13.5$ million, $\$ 2.2$ million, and $\$ 0.26$ million, or a total of $\$ 17.36$ million.

Year-Round Steady Flows. The combination of year-round steady flows and moderate hydrological conditions would yield use values of approximately $\$ 1.7$ million, $\$ 10.4$ million, $\$ 1.9$ million, and $\$ 0.20$ million, or a total of $\$ 14.2$ million for angling, commercial white-water boating, private white-water boating, and white-water boating below Diamond Creek. Assuming dry hydrological conditions, the use value of each of these activities would be $\$ 2.0$ million, $\$ 6.1$ million, $\$ 1.1$ million, and $\$ 0.12$ million, or a total of 
$\$ 9.32$ million. Under wet hydrological conditions, the corresponding values would be $\$ 1.4$ million, $\$ 13.6$ million, $\$ 2.3$ million, and $\$ 0.26$ million, or a total of $\$ 17.56$ million.

\subsubsection{Flaming Gorge Dam}

The effects of each operational scenario on the use value of recreation, particularly angling and white-water boating, below Flaming Gorge Dam were estimated by using existing estimates of such use values (i.e., through the application of benefits transfer). On the basis of results of the literature review summarized in Section 4.3.3, the study by Bishop et al. (1987) was selected as the best candidate for this procedure. This choice was based largely on the relative comparability of the study sites with respect to the quality of trout fishing and the study's explicit focus on the relationship between streamflows and changes in recreation use values.

A limited amount of data was available for comparing the user populations at the policy site and the study site. The "average" angler who fishes for trout below Glen Canyon Dam is 42 years old and has some college education. The median annual income for anglers lies in the $\$ 30,000-40,000$ range. Approximately $87 \%$ of all anglers below Glen Canyon Dam are males. In the case of Flaming Gorge Dam, the "average" angler is 37 years old (information on educational background was not available). The median annual income of anglers below Flaming Gorge Dam lies in the \$35,000-50,000 range. Approximately 92\% of all anglers below Flaming Gorge Dam are males. While these data are somewhat similar, anglers below Flaming Gorge Dam tend to be younger and have somewhat higher incomes than anglers below Glen Canyon Dam. A comparison of demographic characteristics of whitewater boaters in the Grand Canyon and white-water boaters in DNM was not possible because of the absence of data for boaters in the DNM.

Because the study by Bishop et al. (1987) found no significant relationship between streamflows and the value of day boating, the value of this activity was not included in the estimates of the recreation use values associated with each operational scenario at Flaming Gorge Dam. The values reported below are limited to angling below the dam and commercial and private white-water boating in DNM.

In the study by Bishop et al. (1987), estimates of surplus value associated with various flow levels and assumptions about fluctuations in flows were developed from results of the contingent valuation surveys that were conducted. These estimates were then used to construct "flow valuation curves" that relate surplus values to flow levels. Separate flow valuation curves were constructed for commercial white-water boating, private white-water boating, and angling for both constant and fluctuating flows (i.e., a total of six flow valuation curves were constructed). These curves were then used to estimate the recreation benefits associated with the different operational scenarios and hydrological conditions at Glen Canyon Dam. 
Table 5 summarizes the data relating surplus values to flow conditions for each of the six combinations of recreational activity and flow conditions. The estimates of surplus values are provided per trip. Because the use data on recreation below Flaming Gorge Dam are measured in user days (as opposed to number of trips), the values in Table 5 had to be adjusted. According to Bishop et al. (1987), the average trip lengths for angling, commercial white-water boating, and private white-water boating below Glen Canyon Dam are 2.5 days, 8.8 days, and 16.4 days. Surplus values per user day for each activity and flow level were calculated by dividing the value reported in Table 5 by the appropriate average trip length.

To conduct the benefits transfer, the flow valuation curves for angling developed by Bishop et al. (1987) had to be modified further before they could be transferred to the Flaming Gorge site. Modification was required because of the significant difference in flow regimes at the two sites and information on individual preferences for flows at Flaming Gorge. In the case of angling, benefits are maximized at flows of 10,000 cfs below Glen Canyon Dam. However, in the case of Flaming Gorge Dam, angling satisfaction is at a maximum when flows are at $1,100 \mathrm{cfs}$ (shore anglers) and $1,500 \mathrm{cfs}$ (boat anglers). Consequently, the flow valuation functions had to be scaled to reflect the range of preferred flows at Flaming Gorge. The equations used to estimate the surplus values associated with angling below Flaming Gorge Dam were:

Constant Flows

Shore Angling

$$
\begin{array}{ll}
y=-40.16+0.0907 x & \text { for flows up through } 1,100 \mathrm{cfs} \\
y=70.40-0.00982 x & \text { for flows beyond } 1,100 \mathrm{cfs}
\end{array}
$$

Boat Angling

$$
\begin{array}{ll}
y=1.25+0.0389 x & \text { for flows up through } 1,500 \mathrm{cfs} \\
y=70.40-0.0072 x & \text { for flows beyond } 1,500 \mathrm{cfs}
\end{array}
$$

Fluctuating Flows

Shore Angling

$$
\begin{array}{ll}
y=8.96+0.0293 x & \text { for flows up through } 1,100 \mathrm{cfs} \\
y=47.20-0.00545 x & \text { for flows beyond } 1,100 \mathrm{cfs}
\end{array}
$$

Boat Angling

$$
\begin{array}{ll}
y=22.32+0.0126 x & \text { for flows through } 1,500 \mathrm{cfs} \\
y=47.20-0.004 x & \text { for flows beyond } 1,500 \mathrm{cfs}
\end{array}
$$

The resulting modified value functions were then combined with data on use rates and monthly average flows below Flaming Gorge Dam to obtain the estimates presented in 
TABLE 5 Summary of Surplus Values for Angling and Boating below Glen Canyon Dam

Surplus Value per Trip (1991 \$)

\begin{tabular}{|c|c|c|c|c|c|c|}
\hline \multirow[b]{2}{*}{$\begin{array}{l}\text { Flow } \\
\text { (cfs) }\end{array}$} & \multicolumn{3}{|c|}{ Fluctuating Flows } & \multicolumn{3}{|c|}{ Constant Flows } \\
\hline & Angling & $\begin{array}{c}\text { Commercial } \\
\text { White-Water } \\
\text { Boating }\end{array}$ & $\begin{array}{c}\text { Private } \\
\text { White-Water } \\
\text { Boating } \\
\end{array}$ & Angling & $\begin{array}{c}\text { Commercial } \\
\text { White-Water } \\
\text { Boating }\end{array}$ & $\begin{array}{c}\text { Private } \\
\text { White-Water } \\
\text { Boating }\end{array}$ \\
\hline 1,000 & & & & 61 & 56 & 25 \\
\hline 2,000 & & & & 71 & 74 & 37 \\
\hline 3,000 & 81 & 234 & 266 & 81 & 96 & 53 \\
\hline 4,000 & 84 & 251 & 276 & 90 & 123 & 74 \\
\hline 5,000 & 87 & 268 & 286 & 100 & 154 & 99 \\
\hline 6,000 & 90 & 285 & 296 & 110 & 189 & 130 \\
\hline 7,000 & 94 & 302 & 306 & 120 & 227 & 165 \\
\hline 8,000 & 97 & 318 & 316 & 130 & 269 & 204 \\
\hline 9,000 & 100 & 335 & 326 & 140 & 314 & 246 \\
\hline 10,000 & 103 & 352 & 336 & 149 & 361 & 289 \\
\hline 11,000 & 102 & 369 & 346 & 147 & 409 & 334 \\
\hline 12,000 & 100 & 386 & 356 & 144 & 458 & 380 \\
\hline 13,000 & 99 & 402 & 366 & 142 & 507 & 424 \\
\hline 14,000 & 97 & 419 & 376 & 139 & 555 & 468 \\
\hline 15,000 & 96 & 436 & 386 & 137 & 602 & 510 \\
\hline 16,000 & 94 & 453 & 395 & 134 & 648 & 549 \\
\hline 17,000 & 93 & 470 & 405 & 132 & 693 & 587 \\
\hline 18,000 & 91 & 487 & 415 & 129 & 735 & 622 \\
\hline 19,000 & 90 & 503 & 425 & 129 & 776 & 654 \\
\hline 20,000 & 88 & 520 & 435 & 124 & 814 & 684 \\
\hline 21,000 & 87 & 537 & 445 & 122 & 849 & 711 \\
\hline 22,000 & 85 & 554 & 455 & 119 & 882 & 735 \\
\hline 23,000 & 84 & 571 & 465 & 117 & 913 & 756 \\
\hline 25,000 & 81 & 604 & 485 & 111 & 966 & 788 \\
\hline 26,000 & 79 & 621 & 495 & 108 & 988 & 800 \\
\hline 27,000 & 78 & 638 & 505 & 105 & 1,008 & 808 \\
\hline 28,000 & 76 & 655 & 515 & 102 & 1,024 & 814 \\
\hline 29,000 & & & & 98 & 1,038 & 816 \\
\hline 30,000 & & & & 95 & 1,049 & 816 \\
\hline 31,000 & & & & 92 & 1,057 & 812 \\
\hline 32,000 & & & & 88 & 1,062 & 805 \\
\hline 33,000 & & & & 85 & 1,065 & 794 \\
\hline 34,000 & & & & 82 & 1,064 & 781 \\
\hline 35,000 & & & & 78 & 1,060 & 765 \\
\hline
\end{tabular}


TABLE 5 (Cont.)

\begin{tabular}{|c|c|c|c|c|c|c|}
\hline \multirow[b]{3}{*}{$\begin{array}{l}\text { Flow } \\
\text { (cfs) }\end{array}$} & \multicolumn{6}{|c|}{ Surplus Value per Trip (1991 \$) } \\
\hline & \multicolumn{3}{|c|}{ Fluctuating Flows } & \multicolumn{3}{|c|}{ Constant Flows } \\
\hline & Angling & $\begin{array}{c}\text { Commercial } \\
\text { White-Water } \\
\text { Boating }\end{array}$ & $\begin{array}{c}\text { Private } \\
\text { White-Water } \\
\text { Boating }\end{array}$ & Angling & $\begin{array}{c}\text { Commercial } \\
\text { White-Water } \\
\text { Boating }\end{array}$ & $\begin{array}{c}\text { Private } \\
\text { White-Water } \\
\text { Boating }\end{array}$ \\
\hline 36,000 & & & & 75 & 1,054 & 746 \\
\hline 37,000 & & & & 72 & 1,045 & 723 \\
\hline 38,000 & & & & 68 & 1,032 & 698 \\
\hline 39,000 & & & & 65 & 1,017 & 670 \\
\hline 40,000 & & & & 62 & 999 & 639 \\
\hline 41,000 & & & & 58 & 978 & 605 \\
\hline 42,000 & & & & 55 & 955 & 569 \\
\hline 43,000 & & & & 52 & 928 & 530 \\
\hline 44,000 & & & & 48 & 899 & 489 \\
\hline 45,000 & & & & 45 & 867 & 446 \\
\hline
\end{tabular}

Source: Welsh (1993).

Table 6. To select the appropriate flow valuation function in cases where flows were predicted to fluctuate between 6 a.m. and 5 p.m., flows were treated as fluctuating. Data on monthly flow rates, use rates, and corresponding surplus values for angling are presented in Appendix A, Table A.3. Table A.3 also provides disaggregated estimates of use values for each of the four operational scenarios and three hydrological conditions considered in the analysis.

In the case of the white-water boating flow valuation curves, the functions were not modified. Instead, the functions developed by Bishop et al. (1987) were combined with the data on monthly use rates and estimates of monthly flows to produce estimates of the value of white-water boating in DNM. This approach was based on the similarity of the minimum flows at the two locations (1,000 cfs at Glen Canyon and $800 \mathrm{cfs}$ in DNM) and the lack of information suggesting that the flow level at which use values are maximized differed substantially across the two locations. The specific form of the equations used was as follows:

Constant Flows

Commercial White-Water Boating

$$
y=-3.28+0.00417 x
$$

Private White-Water Boating

$$
y=-4.10+0.00227 x
$$


TABLE 6 Summary of Recreation Use Values Associated with Each Operational Scenario at Flaming Gorge Dam

\begin{tabular}{|c|c|c|c|c|c|}
\hline \multirow[b]{2}{*}{$\begin{array}{l}\text { Operational Scenario/ } \\
\text { Hydrological Condition }\end{array}$} & \multicolumn{4}{|c|}{ Use Value by Recreational Activity $\left(10^{6} 1994 \$\right)$} & \multirow{2}{*}{$\begin{array}{c}\text { Percent } \\
\text { Change from } \\
\text { Year-Round High } \\
\text { Fluctuating Flows }\end{array}$} \\
\hline & Angling & $\begin{array}{c}\text { Commercial } \\
\text { White-Water } \\
\text { Boating }\end{array}$ & $\begin{array}{c}\text { Private } \\
\text { White-Water } \\
\text { Boating }\end{array}$ & Total & \\
\hline \multicolumn{6}{|l|}{$\begin{array}{l}\text { Year-round high } \\
\text { fluctuating flows }\end{array}$} \\
\hline Dry & 4.019 & 0.090 & 0.013 & 4.122 & $\mathrm{NA}^{\mathrm{a}}$ \\
\hline Moderate & 4.027 & 0.090 & 0.027 & 4.144 & NA \\
\hline Wet & 2.965 & 0.546 & 0.245 & 3.756 & NA \\
\hline \multicolumn{6}{|l|}{$\begin{array}{l}\text { Seasonally adjusted high } \\
\text { fluctuating flows }\end{array}$} \\
\hline Dry & 3.873 & 0.211 & 0.111 & 4.195 & 1.77 \\
\hline Moderate & 3.974 & 0.279 & 0.151 & 4.404 & 6.27 \\
\hline Wet & 3.118 & 0.300 & 0.110 & 3.528 & -6.07 \\
\hline \multicolumn{6}{|l|}{$\begin{array}{l}\text { Seasonally adjusted } \\
\text { moderate fluctuating } \\
\text { flows }\end{array}$} \\
\hline Dry & 3.873 & 0.127 & 0.030 & 4.030 & -2.23 \\
\hline Moderate & 3.953 & 0.254 & 0.125 & 4.332 & 4.54 \\
\hline Wet & 2.958 & 0.333 & 0.135 & 3.426 & -8.79 \\
\hline \multicolumn{6}{|l|}{$\begin{array}{l}\text { Seasonally adjusted } \\
\text { steady flows }\end{array}$} \\
\hline Dry & 4.655 & 0.132 & 0.032 & 4.819 & 16.81 \\
\hline Moderate & 4.962 & 0.189 & 0.058 & 5.209 & 25.70 \\
\hline Wet & 3.205 & 0.290 & 0.106 & 3.601 & -4.13 \\
\hline
\end{tabular}

a NA indicates not applicable.

Fluctuating Flows

Commercial White-Water Boating

$$
y=20.89+0.00191 x
$$

Private White-Water Boating

$$
y=14.41+0.000606 x
$$

The resulting flow value functions were then combined with data on use rates and monthly average flows below Flaming Gorge Dam to obtain the estimates presented in Table 6. To apply the appropriate flow value function, a determination had to be made as to whether monthly flows should be considered constant or fluctuating. Depending on the volume of water in question and the duration of the up-ramp period, releases from Flaming 
Gorge Dam take between 15 and 17 hours to reach the Gates of Lodore, located at the upper end of DNM. In most cases, fluctuations in flows within DNM occur during the nondaylight hours. According to the decision rule that was developed, flow levels were treated as constant as long as the levels were not predicted to fluctuate more than $20 \%$ between 7 a.m. and 3 p.m. at the Gates of Lodore. Data on monthly flow rates, use rates, and corresponding surplus values for white-water boating are presented in Table A.4. Table A.4 also provides disaggregated estimates of the use value of white-water boating in DNM for each of the four operational scenarios and three hydrological conditions considered in the analysis.

Although the study by Bishop et al. (1987) was selected as the best candidate for the benefits transfer, several potential sources of bias exist. Among these is the fact that part of the use values attributed to recreation below Glen Canyon Dam may reflect the unique scenic beauty of the area. Although the Green River and surrounding environment below Flaming Gorge Dam are considered quite scenic, the possibility exists that the difference between the two sites results in an upward bias in the estimates of the recreational value below Flaming Gorge Dam. Another source of bias is the assumption of constant use rates. To the extent that use rates actually increase or decrease with change in flows, benefits estimates would be biased either downward or upward. This observation applies equally to the benefit estimates for both sites.

Year-Round High Fluctuating Flows. Under this scenario, assuming moderate hydrological conditions, the use values of angling, commercial white-water boating, and private white-water boating would be approximately $\$ 4.027$ million, $\$ 0.09$ million, and $\$ 0.027$ million, or a total of $\$ 4.144$ million. With dry hydrological conditions, the use value of each of these activities would be $\$ 4.019$ million, $\$ 0.09$ million, and $\$ 0.013$ million, or a total of $\$ 4.122$ million, while wet hydrological conditions would yield corresponding values of $\$ 2.965$ million, $\$ 0.546$ million, and $\$ 0.245$ million, or a total of $\$ 3.756$ million.

Seasonally Adjusted High Fluctuating Flows. Under this scenario, assuming moderate hydrological conditions, the use values of angling, commercial white-water boating, and private white-water boating would be approximately $\$ 3.974$ million, $\$ 0.2719$ million, and $\$ 0.151$ million, or a total of $\$ 4.397$ million. With dry hydrological conditions, the use value of each of these activities would be $\$ 3.873$ million, $\$ 0.211$ million, and $\$ 0.111$ million, or a total of $\$ 4.195$ million, while wet hydrological conditions would yield corresponding values of $\$ 3.118$ million, $\$ 0.3$ million, and $\$ 0.11$ million, or a total of $\$ 3.528$ million.

Seasonally Adjusted Moderate Fluctuating Flows. Under this scenario, assuming moderate hydrological conditions, the use values of angling, commercial whitewater boating, and private white-water boating would be approximately $\$ 3.753$ million, $\$ 0.254$ million, and $\$ 0.125$ million, or a total of $\$ 4.132$ million. With dry hydrological conditions, the use value of each of these activities would be $\$ 3.873$ million, $\$ 0.127$ million, and $\$ 0.03$ million, or a total of $\$ 4.03$ million, while wet hydrological conditions would yield 
corresponding values of $\$ 2.958$ million, $\$ 0.333$ million, and $\$ 0.135$ million, or a total of $\$ 3.426$ million.

Seasonally Adjusted Steady Flows. Under this scenario, assuming moderate hydrological conditions, the use values of angling, commercial white-water boating, and private white-water boating would be approximately $\$ 4.962$ million, $\$ 0.189$ million, and $\$ 0.058$ million, or a total of $\$ 5.209$ million. With dry hydrological conditions, the use value of each of these activities would be $\$ 4.655$ million, $\$ 0.132$ million, and $\$ 0.032$ million, or a total of $\$ 4.819$ million, while wet hydrological conditions would yield corresponding values of $\$ 3.205$ million, $\$ 0.29$ million, and $\$ 0.106$ million, or a total of $\$ 3.601$ million.

\subsection{NONUSE VALUES}

As part of its analysis in support of the Glen Canyon Dam EIS, the Bureau of Reclamation is sponsoring a study of nonuse values associated with the riparian environment below Glen Canyon Dam. The preliminary results of focus group sessions conducted by the contractor responsible for completing the study suggest that some individuals may attach nonuse values to this environment. Moreover, evidence suggests that such values may be sensitive to impacts to vegetation and associated wildlife, native fish, Native American Groups, and archaeological sites (Reclamation 1995). To the extent that different operational scenarios result in such impacts, a change in dam operations could result in a change in nonuse values as well. However, it is not clear whether some individuals might also attach nonuse values to the hydroelectric power generated at Glen Canyon Dam (and Flaming Gorge Dam). Assuming this is the case, the same operational scenario could possibly affect this latter category of nonuse values. Furthermore, the potential changes in nonuse values could offset each other to a greater or lesser extent. In any event, the evidence available at this time is insufficient to support any definitive conclusions about the magnitude of nonuse values associated with the different operational scenarios considered here. Consequently, changes in nonuse values were not considered further. 


\section{SUMMMARY}

Strong evidence suggests that changes in streamflows can result in changes in the value of recreational activities such as angling and white-water boating. When all else is constant, increases in streamflows can cause the value of angling and white-water boating to increase. However, in most instances, there is a threshold flow level at which use values are maximized. Increases in flows beyond this threshold cause values to decrease. In addition, the threshold is lower for angling than for white-water boating. Finally, constant flows are preferred over fluctuating flows. There is considerably less evidence on the possible effects that a change in streamflows might have on use rates at a site. Consequently, use rates had to be treated as constant in the analysis presented here.

Expenditures related to angling and white-water boating account for approximately $\$ 24$ million of economic activity in the local economy around Glen Canyon Dam. In the case of Flaming Gorge Dam, these activities account for approximately $\$ 24.8$ million in the local economy. This figure amounts to approximately $0.22 \%$ of the total output in the local economy.

The results of the analysis of changes in use values at Glen Canyon Dam suggest that when use rates are held constant, the range of operational scenarios being considered could result in an increase in the combined use value of angling and white-water boating of as much as $50 \%$ under moderate hydrological conditions. Under dry hydrological conditions, the maximum increase would be about $22 \%$, with most of the increase accruing to anglers. Under wet hydrological conditions, the maximum increase would be about $18 \%$, primarily benefiting white-water boaters.

Changes in the combined use value of angling and white-water boating attributable to different operational scenarios at Flaming Gorge Dam are predicted to range between a maximum decrease of approximately $9 \%$ and a maximum increase of about $26 \%$. Compared with year-round high fluctuating flows, the other operational scenarios combined with wet hydrological conditions would cause the combined use value to decline. Most of the decrease would accrue to white-water boaters. The largest increase in the combined use value would occur under the combination of seasonally adjusted steady flows and moderate hydrological conditions.

Nonuse values, such as existence and bequest values, also are a potentially significant source of the total value attributable to each of the sites included in this study. Previous studies have yielded estimates of nonuse values ranging from $50 \%$ of estimated use values to 73 times as large as estimated use values. However, because of the lack of any firmly established relationship between use values and nonuse values as well as the marginal character of the changes that would occur at each site, estimates of the nonuse value associated with each of the operational scenarios being considered at Glen Canyon Dam and Flaming Gorge Dam were not possible. The problems cited above are compounded by the potential for changes in dam operations that would result in a reduction in nonuse values associated with hydroelectricity. 


\section{REFERENCES}

Bishop, R.C., 1982, "Option Value: An Exposition and Extension," Land Economics 58(1): 1-15.

Bishop, R.C., 1986, "Resource Valuation under Uncertainty: Theoretical Principles for Empirical Research," in Advances in Applied Microeconomics, V.K Smith and A.D. Witte (editors), Vol. 4, pp. 133-152, JAI Press, Greenwich, Conn.

Bishop, R.C., et al., 1987, Glen Canyon Dam Releases and Downstream Recreation: An Analysis of User Preferences and Economic Values, Report to the Recreation Subteam of the Glen Canyon Environmental Studies, Flagstaff, Ariz., by HBRS, Inc., Madison, Wis., Jan.

Boyle, K.J., and J.C. Bergstrom, 1992, "Benefit Transfer Studies: Myths, Pragmatism, and Idealism," Water Resources Research 28(3):657-663.

Brookshire, D.S., et al., 1986, "Existence Values and Normative Economics: Implications for Valuing Water Resources," Water Resources Research 22(11):1509-1518.

Brown, T.C., et al., 1991, "Assessing the Direct Effects of Streamflow on Recreation: A Literature Review," Water Resources Bulletin 27(6):979-989.

Carlson, J.L., 1992, Site Visits to Black Canyon, Gunnison Gorge, Dinosaur National Monument, and Flaming Gorge, memorandum from Carlson (Argonne National Laboratory, Argonne, Ml.) to R.C. Hemphill (Argonne National Laboratory, Argonne, Ml.), June 23. .

Cherry, S., 1993, Colorado River Use Statistics, memorandum from Cherry (National Park Service, Grand Canyon National Park, Grand Canyon, Ariz.) to J.M. Pfingston (Argonne National Laboratory, Argonne, III.), Jan. 19.

Cory, D.C., and B.C. Saliba, 1987, "Requiem for Option Value," Land Economics 63(1):1-10.

Desvousges, W.H., et al., 1992, "Benefit Transfer: Conceptual Problems in Estimating Water Quality Benefits Using Existing Studies," Water Resources Research 28(3):675-683.

Doland, M., 1992, telecommunication from Doland (National Park Service, Glen Canyon National Recreation Area, Page, Ariz.) to J.M. Pfingston (Argonne National Laboratory, Argonne, Ml.), Dec. 4.

Duffield, J., et al., 1991, Economic Value of Recreation and Preservation Benefits of Instream Flow in Two Montana Rivers, Draft Research Paper, Fort Collins, Colorado, U.S. Forest Service, Rocky Mountain Forest and Range Experiment Station.

Fisher, A., and R. Raucher, 1984, "Intrinsic Benefits of Improved Water Quality: Conceptual and Empirical Perspectives," in Advances in Applied Microeconomics, V.K. Smith and A.D. Witte (editors), Vol. 3, pp. 30-66, JAI Press, Greenwich, Conn. 
Freeman, A.M. III, 1979, The Benefits of Environmental Improvement: Theory and Practice, The Johns Hopkins University Press, Md., for Resources for the Future.

Freeman, A.M. III, 1984, "The Sign and Size of Option Value," Land Economics 60:1-13.

Freeman, A.M. III, 1985, "Supply Uncertainty, Option Price, and Option Value," Land Economics 61(2):176-181.

Graham, D.A., 1981, "Cost-Benefit Analysis under Uncertainty," American Economic Review 71(4):715-725.

HBRS, Inc., 1991, Assessing the Potential for a Total Valuation Study of Colorado River Resources, prepared for by HBRS, Inc., Madison, Wisc. for Glen Canyon Environmental Studies, Flagstaff, Ariz.

Loomis, J., 1987, "Balancing Public Trust Resources of Mono Lake and Los Angeles' Water Right: An Economic Approach," Water Resources Research 23(8):1449-1456.

Loomis, J., 1991, "U.S. District Court for Idaho Ruling on Natural Resource Damages Resulting from Steelhead Kill in Little Salmon River: Implications for Value Transfers from Travel Cost and Contingent Valuation Methods under CERCLA," AERE Newsletter 11(2):8-13.

Madariaga, B., and K.E. McConnell, 1987, "Exploring Existence Value," Water Resources Research 23(5):936-942.

Michaelson, E.L., 1977, "An Attempt to Quantify the Esthetics of Wild and Scenic Rivers in Idaho," General Technical Report NC-28 in Proceedings of a Symposium on River Recreation Management and Research, North Central Station, U.S. Forest Service, St. Paul, Minn., pp. 320-328.

Narayanan, R., 1986, "Evaluation of Recreational Benefits of Instream Flows," Journal of Leisure Research 18(2):116-128.

NPS (National Park Service), 1985, Statement for Management, Grand Canyon National Park, Arizona, National Park Service, Grand Canyon National Park, Grand Canyon, Ariz., Apr.

NPS, 1992, Annual Visitation Grand Canyon National Park, 1915-1991, National Park Service, Grand Canyon, Ariz.

Pratt, J., et al., 1991, The Recreation Use Capacity of the Green River Corridor below Flaming Gorge Dam, Institute for Human Ecology, Sonoma, Calif., April.

Public Information Corporation, 1986, Whitewater Rafting in Colorado, Denver, Colo. 
Randall, A., 1989, "Nonuse Benefits," in J.B. Braden and C.D. Kolstad (editors), Measuring the Demand for Environmental Improvement, Final Report ILENR/RE-EA-89/18, prepared for Illinois Department of Energy and Natural Resources.

Reclamation, 1995, Operation of Glen Canyon Dam Colorado River Storage Project, Arizona, Environmental Impact Statement, U.S. Bureau of Reclamation, Salt Lake City, Utah.

Rose, A., and O. Frias, 1993, Economic Impacts of Water-Related Recreational Activity in the Flaming Gorge and Aspinall Regions, prepared by Adam Rose and Associates, State College Penn., for Argonne National Laboratory, Argonne, Ill, Feb. 10.

Rosenthal, D.H., and H.K. Cordell, 1984, "Pricing River Recreation: Some Issues and Concerns," in Proceedings of National Rivers Recreation Symposium, Baton Rouge, La., pp. 272-284,

Rosenthal, D.H., and R.H. Nelson, 1992, "Why Existence Values Should Not Be Used in CostBenefit Analysis," Journal of Policy Analysis and Management 11(1):116-122.

Sams, S.T., 1992, letter from Sams (U.S. Forest Service, Flaming Gorge Ranger District, Manila, Utah) to J.M. Pfingston (Argonne National Laboratory, Argonne, Ml.), July 10.

Schmalensee, R., 1972, "Option Demand and Consumer's Surplus: Valuing Price Changes under Uncertainty," American Economic Review 62:813-824.

Shelby, B., et al., 1992, Streamflow and Recreation, General Technical Report RM-209, U.S. Forest Service, Rocky Mountain Forest and Range Experiment Station.

Smith, V.K, 1984, "A Bound for Option Value," Land Economics 60(3):292-296.

Smith, V.K., 1987a, "Nonuse Values in Benefit Cost Analysis," Southern Economic Journal 54:19-26.

Smith, V.K, 1987b, "Uncertainty, Benefit-Cost Analysis, and the Treatment of Option Value," Journal of Environmental Economics and Management 14:283-292.

Smith, V.K, and Y. Kaoru, 1990, "Signals or Noise? Explaining the Variation in Recreation Benefit Estimates," American Journal of Agricultural Economics 72:419-433.

U.S. Department of Commerce, 1993, Survey of Current Business, vol. 73, no. 1, Jan.

Vandas, S., et al., 1990, Dolores River Instream Flow Assessment, Denver, Colorado Bureau of Land Management, Denver Federal Center.

Walsh, R.G., et al., 1988, Review of Outdoor Recreation Economic Demand Studies with Nonmarket Benefit Estimates: 1968-1988, Technical Report 54, Colorado Water Resources Research Institute, Colorado State University, Fort Collins. 
Walsh, R., et al., 1980, An Empirical Application of a Model for Estimating the Recreation Value of Instream Flow, Completion Report 101, Colorado State University, Colorado Water Resources Research Institute, Fort Collins, Colo., Oct.

Ward, F., 1987, "Economics of Water Allocation to Instream Uses in a Fully Appropriated River Basin: Evidence From a New Mexico Wild River," Water Resources Research 23(3):381-392.

Weisbrod, B.A, 1964, "Collective-Consumption Services of Individual Consumption Goods," Quarterly Journal of Economics 78:471-477.

Welsh, M., 1993, personal communication from Welsh (HBRS, Inc., Madison, Wisc.) to J.L. Carlson (Argonne National Laboratory, Argonne, Il.), Feb. 1.

Willig, R.D., 1976, "Consumers' Surplus without Apology," American Economic Review 66(4):589-597. 


\section{APPENDIX: \\ PROCEDURES USED TO ESTIMATE EXPENDITURES AND USE VALUES}

Tables A.1 and A.2 provide a more detailed view of the procedure used to produce the estimates of the value of recreation-related expenditures presented in Table 3 . The derivation of the values reported in these tables is explained in the notes that accompany each table.

The data presented in Table A.3 provide a more complete picture of the procedure used to estimate the use value of angling below Flaming Gorge Dam. The monthly data on use rates were derived using data on total visitation rates provided by Sams (1992) and data on the distribution of use rates across seasons for angling reported in Pratt et al. (1991). Data on monthly flows were developed internally at Argonne National Laboratory. In the case of angling, the daily average flow rate was used in the appropriate flow valuation function. Flows were considered to be fluctuating if fluctuations exceeded $20 \%$ of the lower flow value and occurred between the hours of 6 a.m. and 5 p.m. In all other cases, flows were treated as constant.

The data presented in Table A.4 provide a more complete picture of the procedure used to estimate the use value of white-water boating within Dinosaur National Monument. The monthly data on use rates were derived using data on total visitation rates provided by the National Park Service (Carlson 1992). Data on monthly flows were developed internally at Argonne National Laboratory. The minimum daily flow rate for white-water boating was used in the appropriate flow valuation function, if flows were considered constant. If the decision rule described in Section 5.4.2 were used and if flows were considered constant, any up-ramp that might occur would reach Dinosaur National Monument during nondaylight hours. Therefore, flows during daylight hours would be at the lower end of the range. In those cases where flows were considered to be fluctuating, the average of the minimum and maximum flows was used in the appropriate flow valuation function. 
TABLE A.1 Green River, Utah: Angling-Related Expenditures (1990 \$)

\begin{tabular}{lcccc}
\hline \multicolumn{1}{c}{ Item } & $\begin{array}{c}\text { Share of } \\
\text { Total Cost }\end{array}$ & $\begin{array}{c}\text { Per Group, } \\
\text { per Trip }\end{array}$ & $\begin{array}{c}\text { Per Person, } \\
\text { per Trip }\end{array}$ & $\begin{array}{c}\text { Per Person, } \\
\text { per Day }\end{array}$ \\
\hline Transportation & 0.26 & 129 & & \\
Food and beverages & 0.21 & 104 & 40 & 20 \\
Lodging & 0.21 & 104 & 33 & 17 \\
Equipment rental & 0.03 & 15 & 33 & 17 \\
Guide service & 0.16 & 79 & 5 & 3 \\
Fishing tackle & 0.09 & 45 & 14 & 7 \\
Other $^{\mathrm{e}}$ & 0.03 & 15 & 5 & 3 \\
Total $^{\mathrm{f}}$ & 0.99 & 491 & 155 & 80 \\
\hline
\end{tabular}

a Source: Pratt et al. (1991, Table 33, p. 118). Shares were calculated on the basis of percentage of average total cost $=\$ 415$. Average total cost was calculated by using midpoint formula. $\$ 750$ was used as midpoint of upper range for food and beverage, equipment rental, fishing tackle, and other. $\$ 1,500$ was used as midpoint of upper range for all other categories.

b Source: Pratt et al. (1991, Table 5, p. 56). Weighted average of total costs per group for anglers $=\$ 495$ after $\$ 70,000$ outlier figure reported on page 119 was discarded.

c Source: Pratt et al. (1991, Table 5, p. 56). Average number of anglers per trip $=3.2$.

d Source: Pratt et al. (1991, p. 107). Average number of days per trip = 2 .

e Category includes primarily license fees, plus shuttles, gear, and camping fees.

f Totals do not match reported values because of rounding. 
TABLE A.2 Green River, Utah: Boating-Related Expenditures (1990 \$)

\begin{tabular}{lcccc}
\hline \multicolumn{1}{c}{ Item } & $\begin{array}{c}\text { Share of } \\
\text { Total Cost }^{\mathrm{a}}\end{array}$ & $\begin{array}{c}\text { Per Group, } \\
\text { per Trip }^{\mathrm{b}}\end{array}$ & $\begin{array}{c}\text { Per Person, } \\
\text { per Trip }^{\mathrm{c}}\end{array}$ & $\begin{array}{c}\text { Per Person, } \\
\text { per Day }^{\mathrm{d}}\end{array}$ \\
\hline Transportation & 0.35 & 128 & 14 & 14 \\
Food and beverages & 0.28 & 102 & 11 & 11 \\
Lodging & 0.29 & 106 & 11 & 11 \\
Equipment rental & 0.05 & 18 & 2 & 2 \\
Other & 0.04 & 15 & 2 & 2 \\
Total & 1.01 & 369 & 40 & 40 \\
\hline
\end{tabular}

a Source: Pratt et al. (1991, Table 33, p. 118). Shares were calculated on the basis of based percentage of average total cost was $=\$ 309$. Average total cost was calculated by using midpoint formula. $\$ 750$ was used as midpoint of upper range for food and beverage, equipment rental, and other. $\$ 1,500$ was used as midpoint of upper range for all other relevant categories.

b Source: Pratt et al. (1991, Table 5, p. 56). Weighted average of total costs per group for boaters $=\$ 366$.

c Source: Pratt et al. (1991, Table 5, p. 56). Average number of boaters per trip $=9.1$.

d Source: Pratt et al. (1991). Average number of days per trip = 1 .

e Category includes license fees, shuttles, gear, and camping fees. 
TABLE A.3 Monthly and Total Annual Use Values for Angling on the Green River by Operational Scenario and Hydrological Condition

\begin{tabular}{|c|c|c|c|c|c|c|c|c|c|c|c|}
\hline \multirow[b]{3}{*}{ Month } & \multirow{3}{*}{$\begin{array}{l}\text { Shore } \\
\text { Angler } \\
\text { Days }\end{array}$} & \multirow{3}{*}{$\begin{array}{c}\text { Boater } \\
\text { Angler } \\
\text { Days }\end{array}$} & \multirow{2}{*}{\multicolumn{3}{|c|}{ Flow Rate (cfs) }} & & & \multicolumn{4}{|c|}{ Estimated Surplus Value (\$) } \\
\hline & & & & & & \multicolumn{2}{|c|}{ Normal Year Value (\$) } & \multicolumn{2}{|c|}{ Wet Year } & \multicolumn{2}{|c|}{ Dry Year } \\
\hline & & & $\begin{array}{c}\text { Normal } \\
\text { Year }\end{array}$ & $\begin{array}{l}\text { Wet } \\
\text { Year }\end{array}$ & $\begin{array}{l}\text { Dry } \\
\text { Year }\end{array}$ & Shore & Boat & Shore & Boat & Shore & Boat \\
\hline \multicolumn{12}{|c|}{ Year-Round High Fluctuating Flows } \\
\hline January & 5,742 & 1,275 & 3,238 & 2,913 & 929 & 169,686 & 43,663 & 179,856 & 45,320 & 207,736 & 43,379 \\
\hline February & 5,186 & 1,152 & 3,238 & 2,425 & 899 & 153,265 & 39,437 & 176,244 & 43,182 & 183,074 & 38,746 \\
\hline March & 6,742 & 1,276 & 1,288 & 2,425 & 897 & 230,707 & 49,146 & 195,127 & 47,809 & 202,352 & 42,865 \\
\hline April & 10,168 & 3,677 & 1,288 & 2,750 & 994 & 408,571 & 141,743 & 327,650 & 133,106 & 387,256 & 128,122 \\
\hline May & 10,507 & 3,800 & 1,613 & 3,075 & 929 & 403,579 & 154,824 & 319,857 & 132,604 & 380,153 & 129,281 \\
\hline June 1-15 & 5,084 & 1,838 & 1,288 & 8,072 & 1,288 & 204,286 & 70,871 & 0 & 22,680 & 204,286 & 70,871 \\
\hline June 15-30 & 2,484 & 2,038 & 1,288 & 8,072 & 1,288 & 99,808 & 78,649 & 0 & 25,026 & 99,808 & 78,549 \\
\hline July & 5,134 & 4,211 & 1,613 & 10,086 & 865 & 197,177 & 171,596 & 0 & 0 & 176,106 & 139,890 \\
\hline August & 5,134 & 4,211 & 1,460 & 5,011 & 1,288 & 201,738 & 170,991 & 108,791 & 144,530 & 206,270 & 162,335 \\
\hline September 1-3 & 497 & 408 & 1,775 & 3,725 & 898 & 18,643 & 16,342 & 16,802 & 17,760 & 17,523 & 13,707 \\
\hline September 4-30 & 3,084 & 2,168 & 1,775 & 3,725 & 898 & 115,715 & 86,943 & 104,288 & 94,488 & 108,762 & 72,925 \\
\hline October & 3,540 & 2,489 & 2,588 & 4,050 & 931 & 117,171 & 91,728 & 108,439 & 102,661 & 128,299 & 84,764 \\
\hline November & 5,567 & 1,234 & 3,725 & 3,725 & 962 & 149,464 & 39,851 & 187,926 & 53,768 & 206,407 & 42,493 \\
\hline December & 5,742 & 1,275 & 3,725 & 2,913 & 962 & 154,447 & 41,179 & 179,856 & 45,320 & 213,287 & 43,909 \\
\hline Total (1991\$) & & & & & & $2,624,258$ & $1,196,803$ & $1,904,737$ & 908,154 & $2,721,319$ & $1,091,837$ \\
\hline$(1994 \$)$ & & & & & & $2,765,967$ & $1,261,430$ & $2,007,593$ & 957,194 & $2,868,270$ & $1,150,796$ \\
\hline \multicolumn{12}{|c|}{ Seasonally Adjusted High Fluctuating Flows } \\
\hline January & 5,742 & 1,275 & 2,425 & 4,700 & 800 & 195,127 & 47,809 & 139,215 & 46,610 & 186,034 & 41,269 \\
\hline February & 5,186 & 1,152 & 2,383 & 4,700 & 800 & 243,742 & 61,310 & 125,743 & 42,100 & 168,030 & 37,275 \\
\hline March & 5,742 & 1,275 & 2,383 & 4,700 & 800 & 269,857 & 67,879 & 139,215 & 46,610 & 186,034 & 41,269 \\
\hline April & 10,168 & 3,677 & 2,588 & 4,700 & 1,189 & 336,628 & 136,489 & 246,544 & 134,430 & 414,058 & 137,156 \\
\hline May & 10,507 & 3,800 & 3,400 & 4,700 & 2,425 & 301,246 & 127,665 & 254,762 & 198,911 & 357,080 & 142,483 \\
\hline June 1-7 & 2,373 & 858 & 4,700 & 7,473 & 4,000 & 57,527 & 31,367 & 0 & 14,237 & 73,836 & 35,691 \\
\hline June 8-15 & 2,712 & 984 & 4,700 & 7,473 & 2,425 & 65,755 & 35,975 & 0 & 16,329 & 92,164 & 36,900 \\
\hline June 16-19 & 664 & 544 & 4,700 & 7,473 & 2,425 & 16,099 & 19,889 & 0 & 9,027 & 22,565 & 20,400 \\
\hline June 20 & 166 & 136 & 4,700 & 7,473 & 800 & 4,025 & 4,972 & 0 & 2,257 & 5,378 & 4,402 \\
\hline June 21 & 166 & 136 & 4,700 & 7,473 & 800 & 4,025 & 4,972 & 0 & 2,257 & 5,378 & 4,402 \\
\hline June $22-30$ & 1,490 & 1,223 & 3,725 & 7,473 & 800 & 50,406 & 53,281 & 0 & 20,288 & 48,289 & 39,575 \\
\hline July 1-9 & 1,490 & 1,223 & 1,938 & 3,725 & 923 & 54,605 & 48,229 & 50,406 & 53,281 & 53,660 & 41,507 \\
\hline July 10-19 & 1,660 & 1,360 & 1,058 & 3,725 & 923 & 66,333 & 48,485 & 56,142 & 59,269 & 59,766 & 46,172 \\
\hline July $20-31$ & 1,992 & 1,632 & 1,058 & 800 & 923 & 79,599 & 58,182 & 64,541 & 62,828 & 71,720 & 55,406 \\
\hline August & 5,134 & 4,211 & 1,158 & 800 & 1,071 & 209,907 & 165,497 & 166,329 & 136,315 & 207,091 & 150,821 \\
\hline September $1-3$ & 497 & 408 & 1,239 & 1,004 & 1,121 & 20,094 & 15,458 & 19,066 & 14,252 & 20,414 & 14,852 \\
\hline September 4-15 & 1,368 & 960 & 1,239 & 1,004 & 1,121 & 55,332 & 36,414 & 52,500 & 33,572 & 56,212 & 34,987 \\
\hline September $16-30$ & 1,713 & 1,205 & 1,239 & 1,715 & 1,121 & 69,291 & 45,689 & 64,847 & 48,591 & 70,392 & 43,898 \\
\hline October & 3,540 & 2,489 & 800 & 1,450 & 839 & 114,709 & 80,580 & 198,833 & 143,524 & 118,755 & 81,878 \\
\hline November & 5,557 & 1,234 & 2,425 & 4,700 & 800 & 188,833 & 46,267 & 134,724 & 45,107 & 180,032 & 39,937 \\
\hline December & 5,742 & 1,275 & 2,425 & 4,700 & 800 & 195,127 & 47,809 & 139,215 & 46,610 & 186,034 & $\$ 41,269$ \\
\hline
\end{tabular}


TABLE A.3 (Cont.)

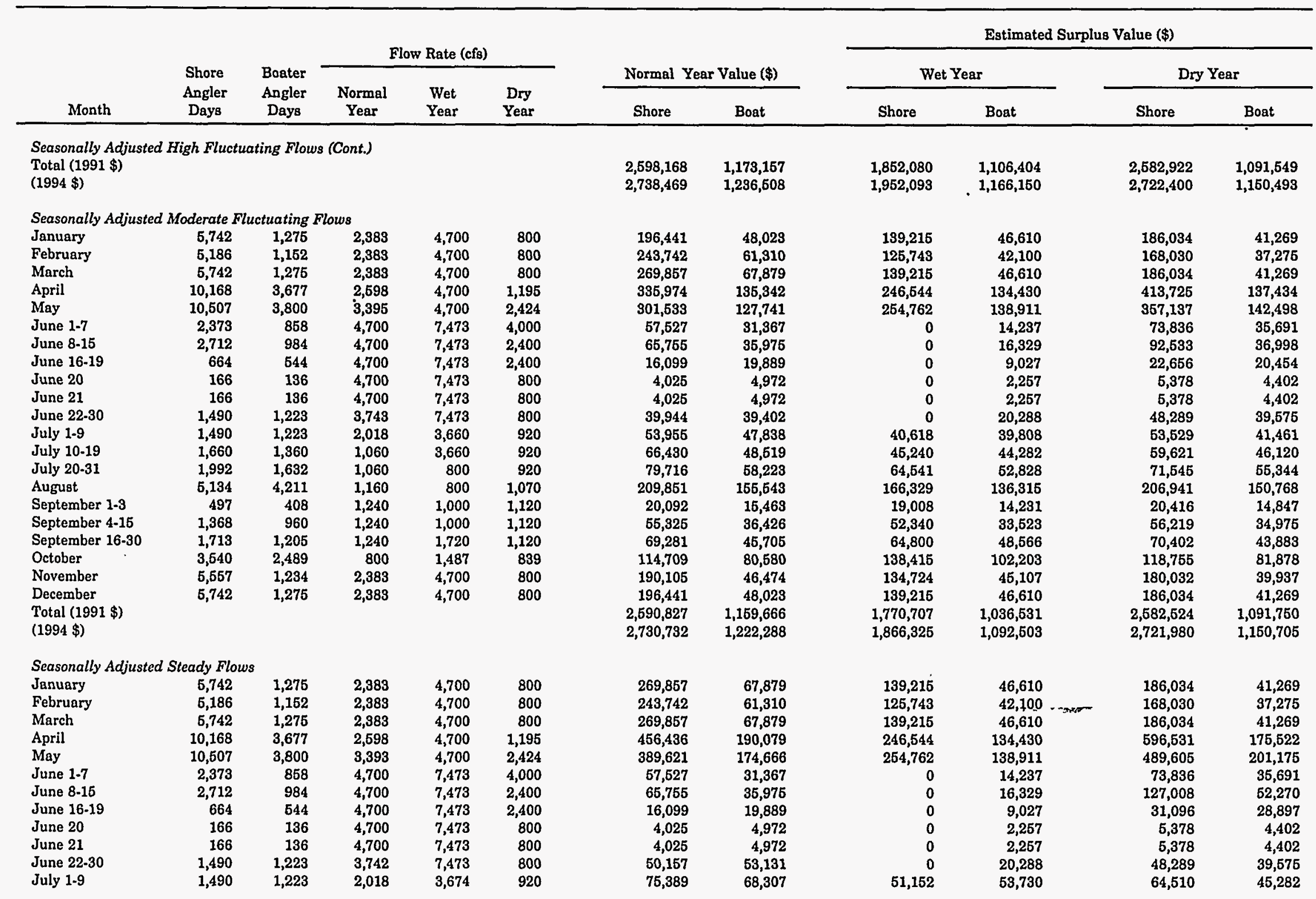


TABLE A.3 (Cont.)

\begin{tabular}{|c|c|c|c|c|c|c|c|c|c|c|c|}
\hline \multirow[b]{3}{*}{ Month } & \multirow{3}{*}{$\begin{array}{c}\text { Shore } \\
\text { Angler } \\
\text { Days }\end{array}$} & \multirow{3}{*}{$\begin{array}{c}\text { Boater } \\
\text { Angler } \\
\text { Days }\end{array}$} & \multicolumn{3}{|c|}{ Flow Rate (cfB) } & & & \multicolumn{4}{|c|}{ Estimated Surplus Value (\$) } \\
\hline & & & \multirow[b]{2}{*}{$\begin{array}{l}\text { Normal } \\
\text { Year }\end{array}$} & \multirow[b]{2}{*}{$\begin{array}{l}\text { Wet } \\
\text { Year }\end{array}$} & \multirow[b]{2}{*}{$\begin{array}{l}\text { Dry } \\
\text { Year }\end{array}$} & \multicolumn{2}{|c|}{ Normal Year Value (\$) } & \multicolumn{2}{|c|}{ Wet Year } & \multicolumn{2}{|c|}{ Dry Year } \\
\hline & & & & & & Shore & Boat & Shore & Boat & Shore & Boat \\
\hline \multicolumn{12}{|c|}{ Seasonally Adjusted Steady Flows (Cont.) } \\
\hline July $10-19$ & 1,660 & 1,360 & 1,060 & 3,674 & 920 & 92,930 & 57,778 & 66,973 & 59,768 & 71,851 & 60,372 \\
\hline July 20-31 & 1,992 & 1,632 & 1,060 & 800 & 920 & 111,616 & 69,334 & 64,541 & 52,828 & 86,222 & 60,446 \\
\hline August & 5,134 & 4,211 & 1,160 & 800 & 1,070 & 302,928 & 195,288 & 166,329 & 136,315 & 292,045 & 180,545 \\
\hline September 1-3 & 497 & 408 & 1,240 & 1,000 & 1,120 & 28,925 & 20,167 & 25,108 & 16,362 & 29,511 & 18,265 \\
\hline September 4-15 & 1,368 & 960 & 1,240 & 1,000 & 1,120 & 79,649 & 47,507 & 69,139 & 38,544 & 81,261 & 43,025 \\
\hline September $16-30$ & 1,713 & 1,205 & 1,240 & 1,720 & 1,120 & 99,742 & 59,607 & 91,667 & 69,882 & 101,761 & 53,984 \\
\hline October & 3,540 & 2,489 & 800 & 1,487 & 839 & 114,709 & 80,580 & 197,547 & 147,107 & 127,233 & 84,357 \\
\hline November & 5,557 & 1,234 & 2,383 & 4,700 & 800 & 261,152 & 65,689 & 134,724 & 45,107 & 180,032 & 39,937 \\
\hline December & 5,742 & 1,275 & 2,383 & 4,700 & 800 & 269,857 & 67,879 & 139,216 & 46,610 & 186,034 & 41,269 \\
\hline Total (1991\$) & & & & & & $3,263,902$ & $1,444,255$ & $1,901,874$ & $1,139,310$ & $3,137,681$ & $1,279,230$ \\
\hline (1994\$) & & & & & & $3,440,152$ & $1,522,245$ & $2,004,575$ & $1,200,833$ & $3,307,116$ & $\$ 1,348,308$ \\
\hline
\end{tabular}

- Total amounts may have been rounded. 
TABLE A.4 Monthly and Total Annual Use Values for White-Water Boating in Dinosaur National Monument by Operational Scenario and Hydrological Condition

\begin{tabular}{|c|c|c|c|c|c|c|c|c|c|c|c|}
\hline \multirow[b]{3}{*}{ Month } & \multirow[b]{3}{*}{$\begin{array}{l}\text { Commercial } \\
\text { Boater Days }\end{array}$} & \multirow[b]{3}{*}{$\begin{array}{c}\text { Private } \\
\text { Boater Days }\end{array}$} & \multirow{2}{*}{\multicolumn{3}{|c|}{ Flow Rate (cis) }} & \multirow{2}{*}{\multicolumn{2}{|c|}{ Normal Year Value (\$) }} & \multicolumn{4}{|c|}{ Estimated Surplus Value (\$) } \\
\hline & & & & & & & & \multicolumn{2}{|c|}{ Wet Year } & \multicolumn{2}{|c|}{ Dry Year } \\
\hline & & & $\begin{array}{c}\text { Normal } \\
\text { Year }\end{array}$ & $\begin{array}{l}\text { Wet } \\
\text { Year } \\
\end{array}$ & $\begin{array}{l}\text { Dry } \\
\text { Year }\end{array}$ & Commercial & Private & Commercial & Private & Commercial & Private \\
\hline \multicolumn{12}{|c|}{ Year-Round High Fluctuating Flows } \\
\hline January & 0 & 0 & 3,238 & 2,913 & 800 & 0 & 0 & 0 & 0 & 0 & 0 \\
\hline February & 0 & 0 & 3,238 & 2,425 & 800 & 0 & 0 & 0 & 0 & 0 & 0 \\
\hline March & 96 & 96 & 800 & 2,425 & 800 & 468 & 66 & 2,451 & 1,523 & 468 & 66 \\
\hline April & 139 & 739 & 800 & 2,750 & 800 & 678 & 504 & 3,635 & 11,873 & 678 & 504 \\
\hline May & 2,677 & 3,686 & 800 & 3,075 & 800 & 13,060 & 2,516 & 71,672 & 69,947 & 13,060 & 2,516 \\
\hline June & 5,505 & 5,067 & 800 & 8,072 & 800 & 26,857 & 3,459 & 171,057 & 64,174 & 26,857 & 3,459 \\
\hline July & 4,578 & 3,707 & 800 & 10,086 & 800 & 22,335 & $\mathbf{2 , 5 3 0}$ & 187,460 & 64,798 & 22,335 & 2,530 \\
\hline August & 3,813 & 2,376 & 800 & 5,011 & 800 & 18,602 & 1,622 & 69,559 & 15,658 & 18,602 & 1,622 \\
\hline September & 699 & 1,484 & 800 & 4,700 & 800 & 3,410 & 1,013 & 11,943 & 8,988 & 3,410 & 1,013 \\
\hline October & 0 & 870 & 2,588 & 4,700 & 800 & 0 & 13,892 & 0 & 5,269 & 0 & 594 \\
\hline November & 0 & 24 & 4,700 & 4,700 & 800 & 0 & 145 & 0 & 145 & 0 & 16 \\
\hline December & 0 & 0 & 4,700 & 2,913 & 800 & 0 & 0 & 0 & 0 & 0 & 0 \\
\hline Total (1991 \$) & & & & & & 85,411 & 25,748 & 617,767 & 232,377 & 85,411 & 12,320 \\
\hline (1994\$) & & & & & & 90,024 & 27,138 & 545,726 & 244,925 & 90,024 & 12,986 \\
\hline \multicolumn{12}{|c|}{ Seasonally Adjusted High Fluctuating Flows } \\
\hline January & 0 & 0 & 2,425 & 4,700 & 800 & 0 & 0 & 0 & 0 & 0 & 0 \\
\hline February & 0 & 0 & 2,383 & 4,700 & 800 & 0 & 0 & 0 & 0 & 0 & 0 \\
\hline March & 96 & 96 & 2,383 & 4,700 & 800 & 895 & 247 & 1,640 & 581 & 468 & 66 \\
\hline April & 139 & 739 & 2,588 & 4,700 & 870 & 3,692 & 11,801 & 2,375 & 4,476 & 703 & 560 \\
\hline May & 2,677 & 3,686 & 3,400 & 4,700 & 2,425 & 73,334 & 60,673 & 45,738 & 22,326 & 68,348 & 58,495 \\
\hline June 1-7 & 1,285 & 1,182 & 4,700 & 7,473 & 4,000 & 21,955 & 7,159 & 36,437 & 13,426 & 18,737 & 5,807 \\
\hline June 8-15 & 1,468 & 1,351 & 4,700 & 7,473 & 2,426 & 25,082 & 8,183 & 41,626 & 15,345 & 37,481 & 21,440 \\
\hline June $16-19$ & 794 & 676 & 4,700 & 7,473 & 2,425 & 12,541 & 4,094 & 20,813 & 7,678 & 18,740 & 10,728 \\
\hline June 20 & 184 & 169 & 4,700 & 7,473 & 800 & 3,144 & 1,024 & 5,217 & 1,920 & 898 & 115 \\
\hline June 21 & 183 & 169 & 4,700 & 7,473 & 800 & 3,127 & 1,024 & 5,189 & 1,920 & 893 & 115 \\
\hline June 22-30 & 1,651 & 1,520 & 3,725 & 7,473 & 800 & 46,252 & 25,319 & 46,815 & 17,265 & 8,055 & 1,038 \\
\hline July $1-9$ & 1,329 & 1,076 & 1,938 & 4,700 & 800 & 32,695 & 16,758 & 22,707 & 6,517 & 6,484 & 734 \\
\hline July $10-19$ & 1,477 & 1,196 & 1,058 & 4,700 & 800 & 8,204 & 1,152 & 25,236 & 7,244 . & 7,206 & 816 \\
\hline July $20-31$ & 1,772 & 1,435 & 890 & 800 & 800 & 9,059 & 1,118 & 8,645 & 980 & 8,645 & 980 \\
\hline August & 3,813 & 2,376 & 990 & 800 & 950 & 20,494 & 2,110 & 18,602 & 1,622 & 20,092 & 2,006 \\
\hline September 1-3 & 70 & 149 & 1,070 & 800 & 1,000 & 391 & 146 & 342 & 102 & 378 & 134 \\
\hline September 4-15 & 280 & 594 & 1,070 & 800 & 1,000 & 1,664 & 580 & 1,366 & 405 & 1,512 & 634 \\
\hline September $16-30$ & 350 & 742 & 1,070 & 1,470 & 1,000 & 1,955 & 724 & 2,335 & 1,063 & 1,890 & 667 \\
\hline October & 0 & 870 & 800 & 1,450 & 800 & 0 & 594 & 0 & 1,226 & 0 & 594 \\
\hline November & 0 & 24 & 2,425 & 4,700 & 800 & 0 & 381 & 0 & 145 & 0 & 16 \\
\hline December & 0 & 0 & 2,425 & 4,700 & 800 & 0 & 0 & 0 & 0 & 0 & 0 \\
\hline TOTAL (1991) & & & & & & 264,285 & 143,085 & 285,085 & 104,240 & 200,531 & 104,845 \\
\hline (1994) & & & & & & 278,556 & 160,812 & 300,480 & 109,869 & 211,360 & 110,507 \\
\hline
\end{tabular}


TABLE A.4 (Cont.)

\begin{tabular}{|c|c|c|c|c|c|c|c|c|c|c|c|}
\hline \multirow[b]{3}{*}{ Month } & \multirow[b]{3}{*}{$\begin{array}{c}\text { Commercial } \\
\text { Boater Days }\end{array}$} & \multirow[b]{3}{*}{$\begin{array}{c}\text { Private } \\
\text { Boater Days }\end{array}$} & \multirow{2}{*}{\multicolumn{3}{|c|}{ Flow Rate (cfe) }} & & & \multicolumn{4}{|c|}{ Estimated Surplus Value (\$) } \\
\hline & & & & & & \multicolumn{2}{|c|}{ Normal Year Value (\$) } & \multicolumn{2}{|c|}{ Wet Year } & \multicolumn{2}{|c|}{ Dry Year } \\
\hline & & & $\begin{array}{c}\text { Normal } \\
\text { Year }\end{array}$ & $\begin{array}{l}\text { Wet } \\
\text { Year }\end{array}$ & $\begin{array}{l}\text { Dry } \\
\text { Year }\end{array}$ & Commercial & Private & Commercial & Private & Commercial & Private \\
\hline \multicolumn{12}{|c|}{ Seasonally Adjusted Moderate Fluctuating Flows } \\
\hline January & 0 & 0 & 2,221 & 4,700 & 800 & 0 & $\mathbf{0}$ & 0 & 0 & 0 & 0 \\
\hline February & 0 & 0 & 2,383 & 4,700 & 800 & 0 & 0 & 0 & 0 & 0 & 0 \\
\hline March & 96 & 96 & 2,383 & 4,700 & 800 & 895 & 247 & 1,640 & 681 & 468 & 66 \\
\hline April & 139 & 739 & 2,436 & 4,700 & 1,033 & 1,318 & 1,951 & 2,375 & 4,476 & 763 & 691 \\
\hline May & 2,677 & 3,686 & 3,395 & 4,700 & 2,262 & 73,308 & 60,662 & 45,738 & 22,325 & 23,975 & 8.891 \\
\hline June 1-7 & 1,285 & 1,182 & 4,700 & 7,473 & 4,000 & 21,965 & 7,159 & 36,437 & 13,426 & 18,737 & 5,807 \\
\hline June 8-15 & 1,468 & 1,351 & 4,700 & 7,473 & 2,238 & 25,082 & 8,183 & 41,626 & 15,345 & 13,042 & 3,217 \\
\hline June 16-19 & 734 & 676 & 4,700 & 7,473 & 2,238 & 12,541 & 4,094 & 20,813 & 7,678 & 6,621 & 1,610 \\
\hline June 20 & 184 & 169 & 4,700 & 7,473 & 800 & 3,144 & 1,024 & 5,217 & 1,920 & 898 & 115 \\
\hline June 21 & 183 & 169 & 4,700 & 7,473 & 800 & 3,127 & 1,024 & 5,189 & 1,920 & 893 & 115 \\
\hline June $22-30$ & 1,651 & 1,620 & 3,743 & 7,473 & 800 & 46,309 & 25,336 & 46,815 & 17,265 & 8,055 & 1,038 \\
\hline July 1-9 & 1,329 & 1,076 & 1,856 & 3,660 & 858 & 10,318 & 2,042 & 37,067 & 17,881 & 6,684 & 801 \\
\hline July $10-19$ & 1,477 & 1,196 & 976 & 3,660 & 858 & 7,884 & 1,044 & 41,194 & 19,875 & 7,428 & 891 \\
\hline July $20-31$ & 1,772 & 1,435 & 976 & 800 & 858 & 9,459 & 1,252 & 8,645 & 980 & 8,911 & 1,069 \\
\hline August & 3,813 & 2,376 & 1,076 & 800 & 1,010 & 21,363 & 2,335 & 18,602 & 1,622 & 20,695 & 2,162 \\
\hline September 1-3 & 70 & 149 & 1,156 & 898 & 1,060 & 407 & 160 & 359 & 117 & 389 & 144 \\
\hline September 4-15 & 280 & 594 & 1,156 & 898 & 1,060 & 1,629 & 637 & 1,437 & 468 & 1,557 & 573 \\
\hline September $16-30$ & 350 & 742 & 1,156 & 1,698 & 1,060 & 2,036 & 796 & 2,460 & 1.175 & 1,946 & 716 \\
\hline October & 0 & 870 & 800 & 1,325 & 820 & 0 & 594 & $\begin{array}{r}2,+60 \\
0\end{array}$ & 1,100 & 0 & 612 \\
\hline November & 0 & 24 & 2,221 & 4,700 & 800 & 0 & $\begin{array}{r}094 \\
57\end{array}$ & 0 & 1,100 & 0 & $\begin{array}{r}012 \\
16\end{array}$ \\
\hline December & 0 & 0 & 2,221 & 4,700 & 800 & 0 & 0 & 0 & 0 & 0 & 0 \\
\hline Total (1991\$) & & & & & & 240,772 & 118,595 & 315,618 & 128,299 & 120,960 & 28,534 \\
\hline$(1994 \$)$ & & & & & & 253,774 & 124,999 & 332,661 & 135,227 & 127,492 & 30,075 \\
\hline \multicolumn{12}{|c|}{ Seasonally Adjusted Steady Flows } \\
\hline January & 0 & 0 & 2,383 & 4,700 & 800 & 0 & 0 & 0 & 0 & 0 & 0 \\
\hline February & 0 & 0 & 2,383 & 4,700 & 800 & 0 & 0 & 0 & 0 & 0 & 0 \\
\hline March & 96 & 96 & 2,383 & 4,700 & 800 & 895 & 247 & 1,640 & 581 & 468 & 66 \\
\hline April & 139 & 739 & 2,698 & 4,700 & 1,195 & 1,387 & 2,112 & 2,375 & 4,476 & $\begin{array}{l}400 \\
823\end{array}$ & 825 \\
\hline May & 2,677 & 3,686 & 3,393 & 4,700 & 2,424 & 33,517 & 14,687 & 45,738 & 22,325 & 25,283 & 9,675 \\
\hline June 1-7 & 1,285 & 1,182 & 4,700 & 7,473 & 4,000 & 21,955 & 7,159 & 36,437 & 13,426 & 18.737 & 5,807 \\
\hline June 8-15 & 1,468 & 1,351 & 4,700 & 7,473 & 2,400 & 25,082 & 8.183 & 41.626 & 15,345 & 13.757 & 3.503 \\
\hline June 16-19 & 734 & 676 & 4,700 & 7,473 & 2,400 & 12,541 & 4,094 & 20,813 & 7,678 & 6,879 & 1,753 \\
\hline June 20 & 184 & 169 & 4,700 & 7,473 & 800 & 3,144 & 1,024 & 5,217 & 1,920 & 898 & 115 \\
\hline June 21 & 183 & 169 & 4,700 & $\mathbf{7 , 4 7 3}$ & 800 & 3,127 & 1,024 & 5,189 & 1,920 & 893 & 115 \\
\hline June 22-30 & 1,651 & 1,520 & 3,742 & 7,473 & 800 & 22,606 & 6.857 & $\begin{array}{r}46,815 \\
46.04\end{array}$ & 17,265 & 8,055 & 1.038 \\
\hline July $1-9$ & 1,329 & 1,076 & 2,018 & 3,674 & 920 & 10,943 & 2,259 & 17,890 & $\begin{array}{r}4,742 \\
4,200\end{array}$ & 6,899 & $\begin{array}{r}1,000 \\
873\end{array}$ \\
\hline July $10-19$ & 1,477 & 1,196 & 1,060 & 3,674 & 920 & 8,212 & 1,154 & 19,883 & 5,271 & 7,667 & 971 \\
\hline July $20-31$ & 1,772 & 1,435 & 1,060 & 800 & 920 & 9,852 & 1,385 & 8,645 & 980 & 9,198 & 1,165 \\
\hline August & 3,813 & 2,376 & 1,160 & 800 & 1,070 & 22,219 & 2,558 & 18,602 & 1622 & 21302 & 2,320 \\
\hline
\end{tabular}


TABLE A.4 (Cont.)

\begin{tabular}{|c|c|c|c|c|c|c|c|c|c|c|c|}
\hline \multirow[b]{3}{*}{ Month } & \multirow[b]{3}{*}{$\begin{array}{l}\text { Commercial } \\
\text { Boater Days }\end{array}$} & \multirow[b]{3}{*}{$\begin{array}{c}\text { Private } \\
\text { Boater Days }\end{array}$} & \multirow{2}{*}{\multicolumn{3}{|c|}{ Flow Rate (cfs) }} & & & \multicolumn{4}{|c|}{ Estimated Surplus Value (\$) } \\
\hline & & & & & & \multicolumn{2}{|c|}{ Normal Year Value (\$) } & \multicolumn{2}{|c|}{ Wet Year } & \multicolumn{2}{|c|}{ Dry Year } \\
\hline & & & $\begin{array}{c}\text { Normal } \\
\text { Year }\end{array}$ & $\begin{array}{l}\text { Wet } \\
\text { Year }\end{array}$ & $\begin{array}{l}\text { Dry } \\
\text { Year }\end{array}$ & Commercial & Private & Commercial & Private & Commercial & Private \\
\hline \multicolumn{12}{|c|}{ Seasonally Adjusted Steady Flows (Cont.) } \\
\hline September 1-3 & 70 & 149 & 1,240 & 1,000 & 1,120 & 423 & 174 & 378 & 134 & 400 & 154 \\
\hline September 4-15 & 280 & 594 & 1,240 & 1,000 & 1,120 & 1,692 & 693 & 1,512 & 634 & 1,602 & 613 \\
\hline September $16-30$ & 350 & 742 & 1,240 & 1,720 & 1,120 & 2,115 & 866 & 2,581 & 1,284 & 2,002 & 766 \\
\hline October & 0 & 870 & 800 & 1,487 & 839 & 0 & 594 & 0 & 1,264 & 0 & 630 \\
\hline November & 0 & 24 & 2,383 & 4,700 & 800 & 0 & 62 & 0 & 145 & 0 & 16 \\
\hline December & 0 & 0 & 2,383 & 4,700 & 800 & 0 & 0 & 0 & 0 & 0 & 0 \\
\hline Total (1991\$) & & & & & & 179,709 & 55,132 & 275,344 & 100,911 & 124,861 & 90,404 \\
\hline$(1994 \$)$ & & & & & & 189,413 & 68,109 & 290,213 & 106,361 & 131,603 & 32,046 \\
\hline
\end{tabular}




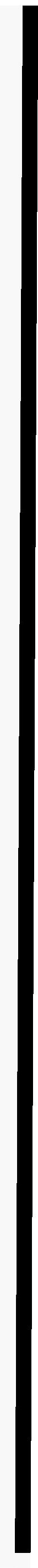

